\title{
سبل تنشيط السياحة الرياضية بمحافظة البحر الأحمر
}

\section{Ways to activate the sports tourism in the Red Sea Governorate}

• أ.م.د//محمود السيد اسماعيل الأصبح

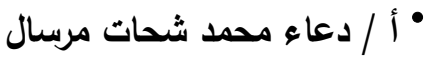

\section{ملغص البحث}

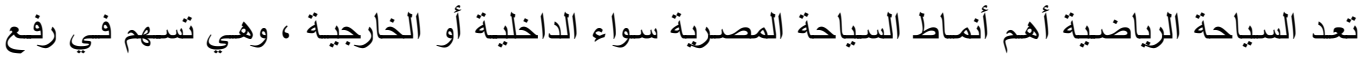

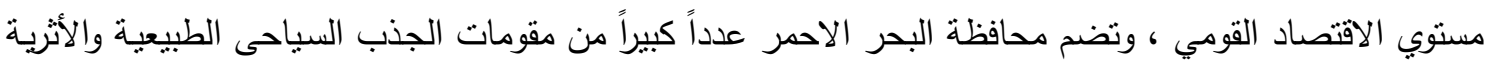

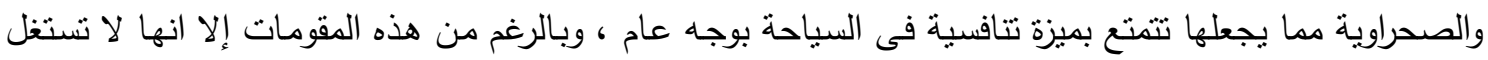

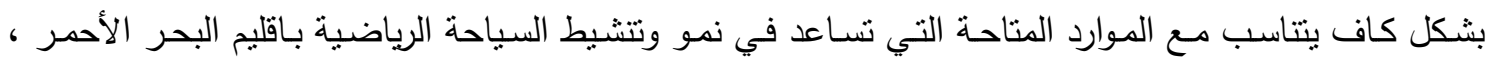

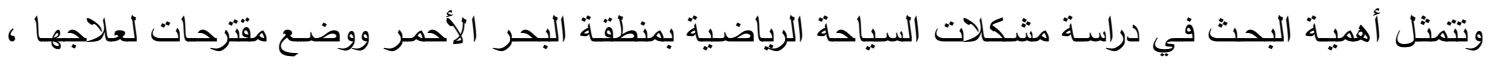

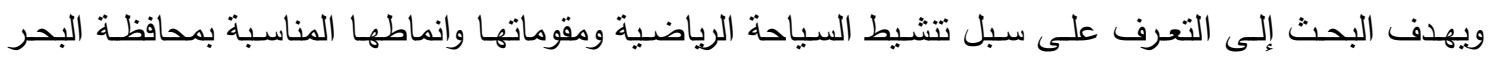

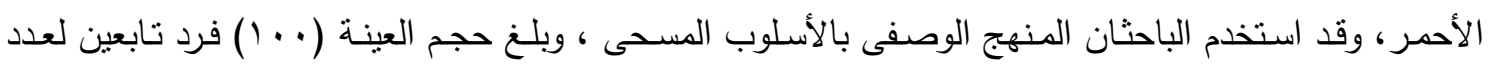

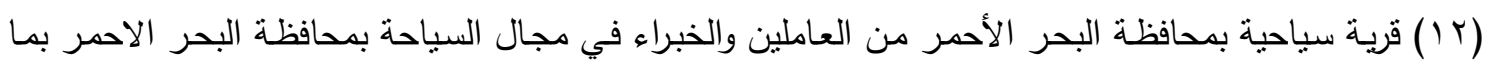

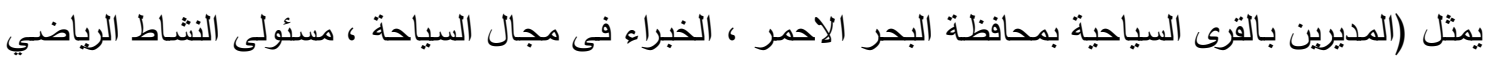

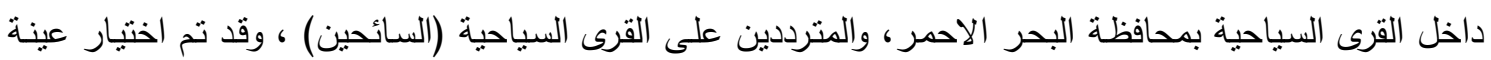

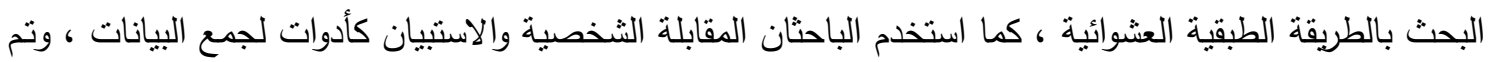

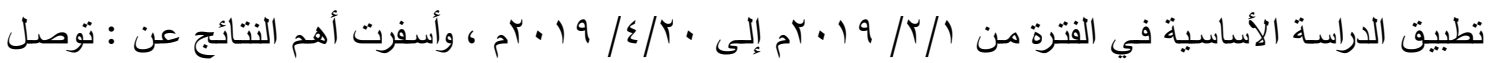

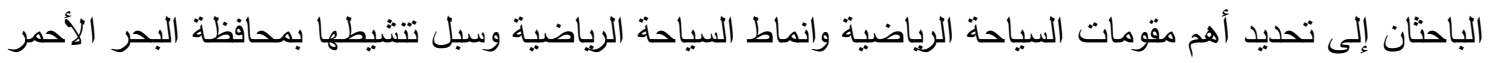

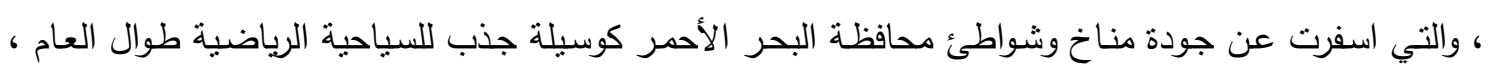

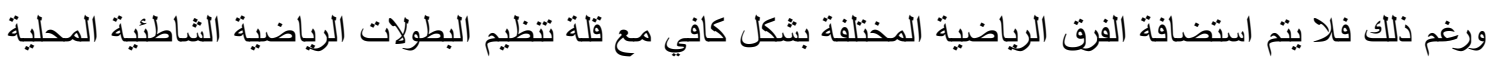

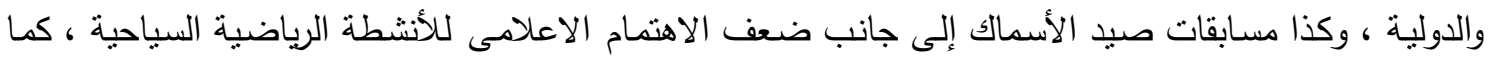

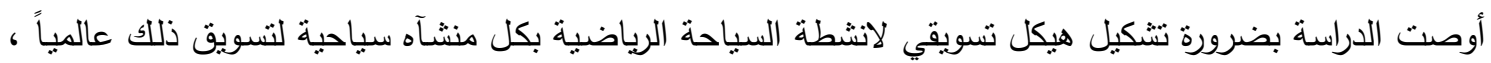
مع تثكيل لجان منبقة من هيئة تتشيط السياحة تختص بالانشطة الرياضية السياحية. 
تعتبر محافظـة البحر الأحمر مـن أهم محافظـات مصـر مـن حيث المقومـات السياحية والمتمثلة في المناخ المعتدل طوال أيام العام والثـواطئ المتتوعـة طولا وعرضـاً والأحياء المائيـة

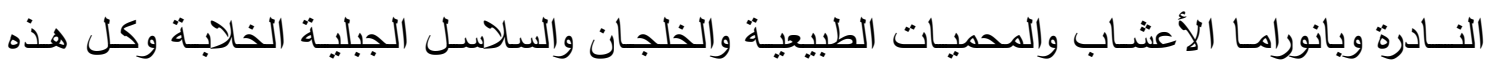
المقومات لا توجد مجتمعة في كثير من بلدان العـالم ، وهي بذلك تمثنل مصدراً هامـاً للسياحة

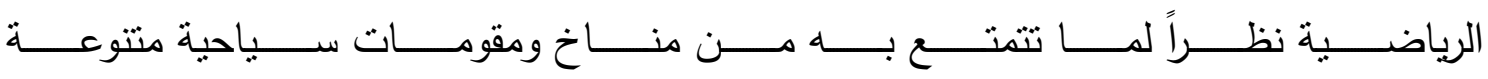

(www.redsea.gov.eg/tourism/default.aspx) وتعد السياحة الرباضية من أهم أنماط السياحة التي تناهم بشكل فعال فى تنشيط حركة السياحة المصرية سواء الداخلية أو الخارجية ، وبالتالي رفع مستوي الاقتصاد القومي ، وفي الوقت الحاضر لم تعد السياحة تقتصر علي زبارة الآثار القديمة التي خلفها الأجداد ، لكن بدأ هناك اتجاه عالمي جديد لربط السياحة بالرياضة بما يحقق خدمة كلاً منهما للأخر وتعتبر السياحة في مصر

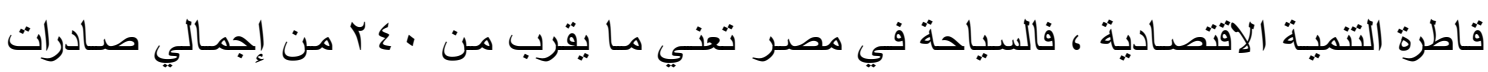

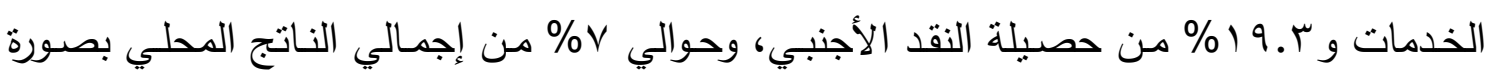
مباشرة، كما تعتبر من أهم قطاعات الدولة توفيراً لفرص العمل حيث يصل نسبة الذين يعملون بها سواء بصورة مباشرة أو غير مباشرة إلى حوالي ج. ا ( \% من إجمالي حجم العمالة في الدولة . وتمثل السياحة مجموعة من العلاقات والخدمات المرتبطة بعملية تغيير المكان تغييراً وقتياً وتلقائياً وليس لأسباب تجارية أو حرفية فقط ، فالعلاقات في السياحة مجموعتان منفصلتان تسمي الأولي مجموعة العلاقات المادية. حيث ينتفع السائح بالعديد من الخدمات مقابل دفع اجر مادي، وتســي الثانيـة مجموعـة العلاقـات غير الماديـة (الإنسـانية أو المعنويـة) والتي تتـتج مـن اتصـال السـائح وتعامله مـع شعوب الدول المختلفة والتي يزودها بمقوماتها التقافية والسلوكية والاجتماعية

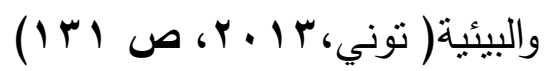

وتتبير العديد من الدراسات لدور السياحة الرياضية وأهميتها في تتشيط السياحة والرياضـة بوجه عام سواء على المستوى المحلى أو الدولي ، ومن أمتلـة هذه الدراسـات ، دراسـة كلاً من: " (علي،ه ( • ب) "إستراتيجية مقترحة لاستثمار أنشطة ألعاب القوى الترويحية في ضوء أبعاد التتمية

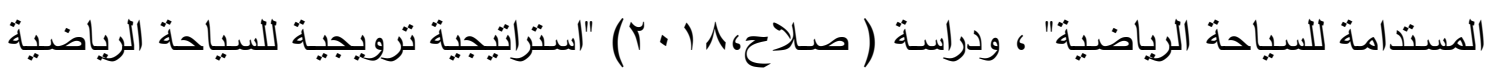

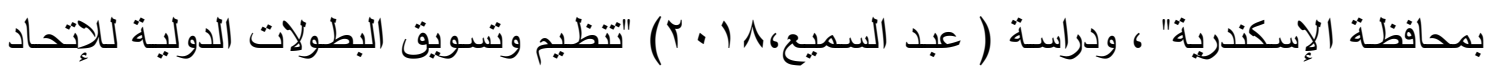

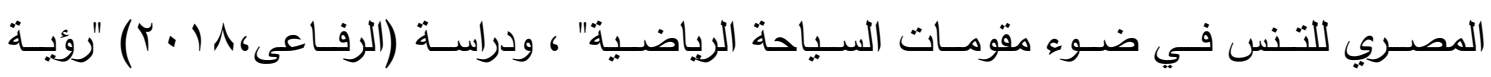
سوسـيولوجية لـدور الإعـلام فـي تتميـة السـياحة الرياضـية فـي المجتمـع المصـري" ، ودراسـة 


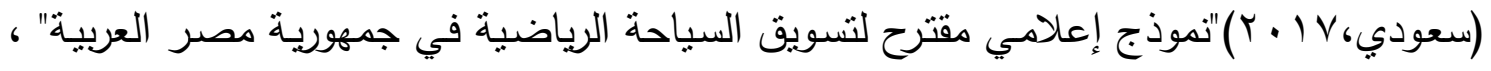

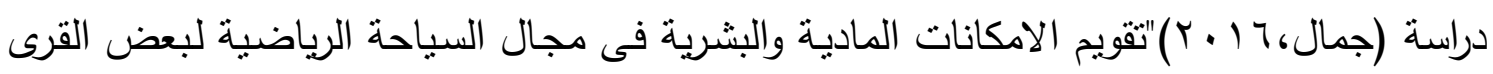

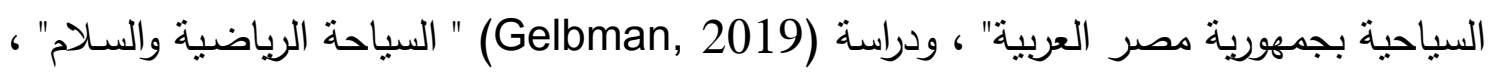

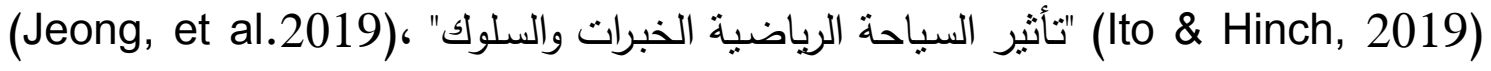

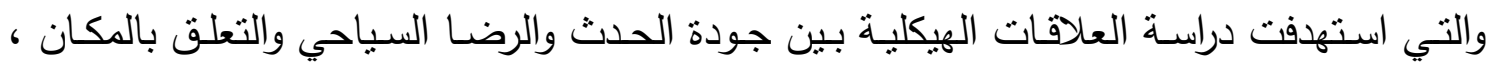

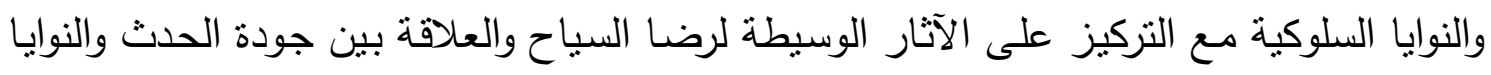
السلوكية ، ودراسة (Kolenberg \& Batra, 2019)" دور الرياضة في تتمية السياحة" ، ودراسة الإنة

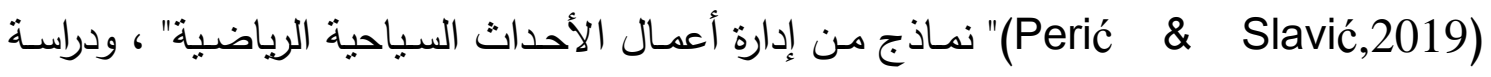
(Tadini, et al,2019)

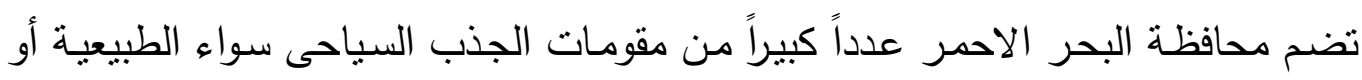

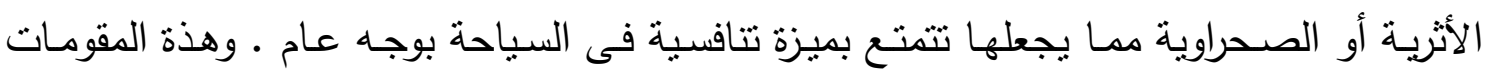

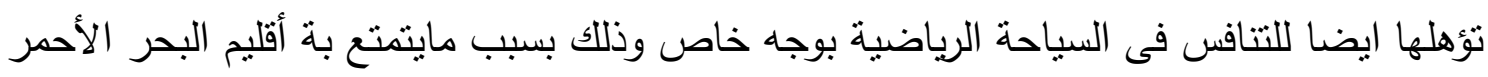

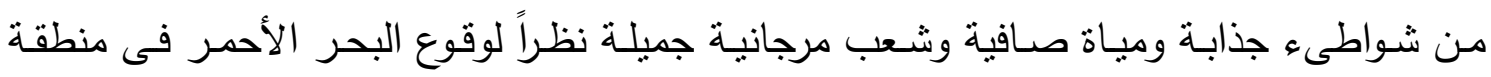

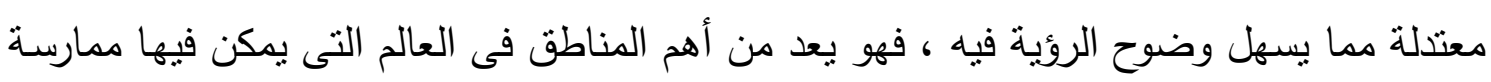

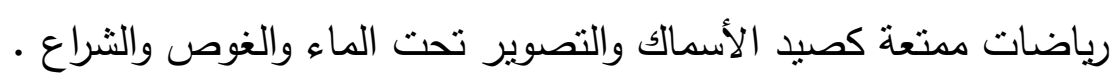

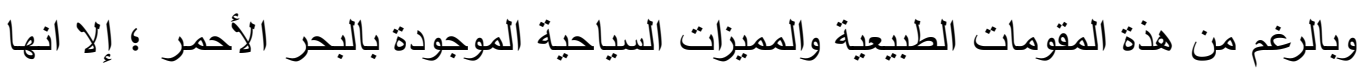

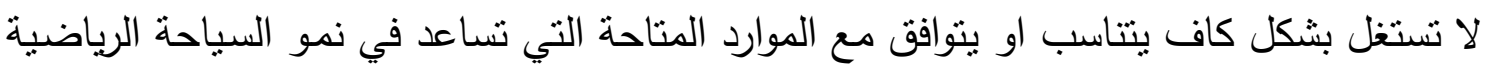

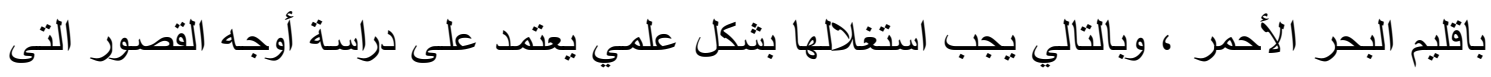

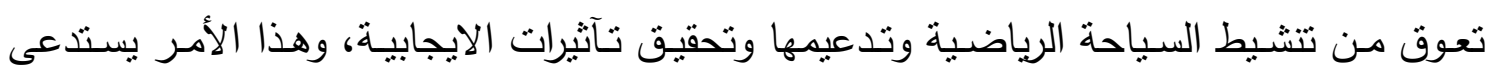

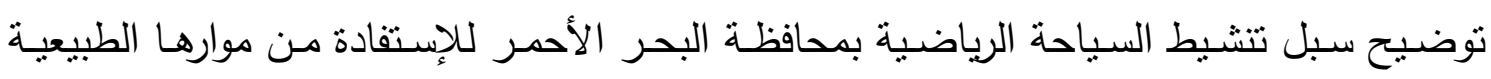
ووضعها على الخريطة السياحية العالمية ، ويتطلب ذلك التركيز على تتشيط السياحة الرياضية كأحد أهم مرتكزات تتشيط السياحة بوجة عام بمحافظة البحر الأحمر .

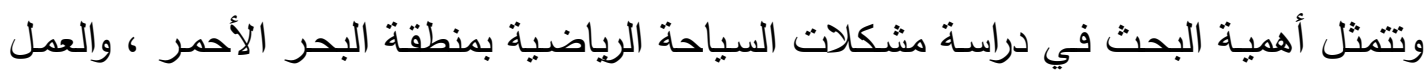

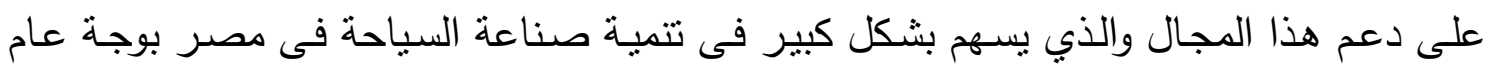

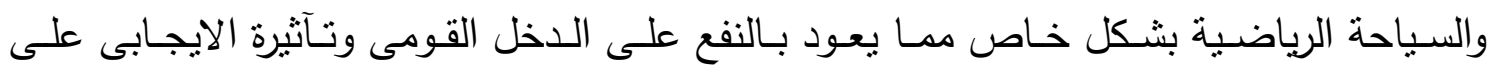

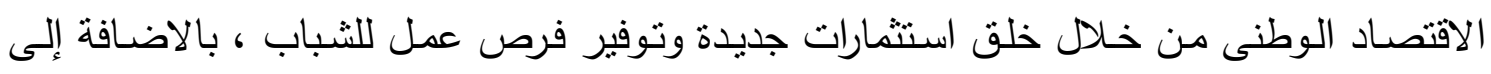

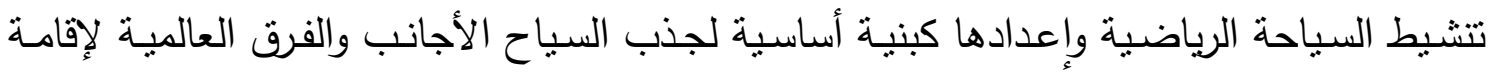
المعكرات التدريبية فى البحر الاحمر . 


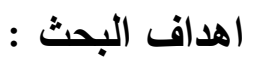

التعرف على سبل تنشيط السياحة الرياضية ومقوماتها وانماطها المناسبة بمحافظة البحر الأحمر • تساؤلات البحث :

- ما هي سبل تتشيط السياحة الرياضية ومقوماتها وانماطها المناسبة بمحافظة البحر الأحمر؟ إجراءات البحث: - ت

منهج البحث: إستخدم الباحتنان المنهج الوصفي بالأسلوب المسحي • مجتمع البحث : قام الباحثان بتحديد المجتمع الأصلي للاراسة من القرى السياحية الواقعة في نطاق محافظة البحر الاحمر ، وكذلك من العاملين والخبراء في مجال السياحة من مديري القرى السياحية ، إلى جانب مسئولى النشـاط الرياضـي داخل القرى السياحية ، المترددين على القرى السياحية

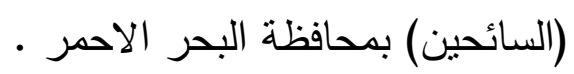
عينـة البحث : اختار الباحثنان عينـة الدراسـة الأساسية من العاملين والخبراء في مجال السياحة بمحافظة البحر الاحمر بما يمثل (المديرين بالقرى السياحية بمحافظة البحر الاحمر ، الخبراء فى مجـال السـياحة ، مسـؤولى النشـاط الرياضـي داخـل القـرى السـياحية بمحافظــة البحـر الاحمـر ، المترددين على القرى السياحية (السائحين) ، وقد تم اختيار عينة البحث بالطريقة الطبقية العشوائية ، حيث بلغ حجم العينة الأساسية ( . () فرد ، وقد راعى الباحثان شروط عند اختيار فئات عينة الدراسـة تتمثل في أن لا تقل الخبرة العمليـة عن خمس سنوات سواء لمديري القري السياحية أو الخبراء أو مسئولي النشاط الرياضي داخل القري السياحية ، وأن تكون على درجة كافية بأنشطة القربـة السياحية سواء كانت الداخلية أو الخارجيـة ، والجدول التالي يوضـح توصيف عينة البحث

\section{(1) (1) (1)}

توصيف عينة البحث الاساسية من العاملين والخبراء في مجال السياحة بمحافظة البحر الاحمر

\begin{tabular}{|c|c|c|}
\hline العينة الاساسية & فئة العينة & م \\
\hline ir & مديري القرى السياحية المتوفرة فى محافظة البحر الاحمر & -1 \\
\hline ir & خبراء فى مجال السياحة & $-r$ \\
\hline 1. & مسؤلى النشاط الرياضي داخل القرى السياحية & $-r$ \\
\hline 97 & المترددين على القرى السياحية (السائحين) & $-\varepsilon$ \\
\hline $1 \ldots$ & الاجمالي & \\
\hline
\end{tabular}

يوضح جدول (1) توصيف عينة البحث الاساسية من العاملين والخبراء في مجال السياحة بمحافظة البحر الاحمر حيث بلغ إجمالي العينة الأساسية ( . . (1) فرد مقسمة إلى (Y I) مدير 
بالقرى السياحية في محافظة البحر الاحمر ، (Y ( ) فرد من الخبراء فى مجال السياحة ، (· ( )

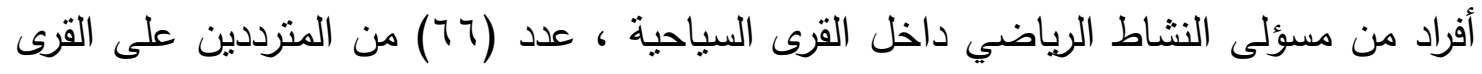
السياحية (السائحين) بمحافظة البحر الاحمر . وسائل جمع البيانات :

اسـتخدم الباحثنان المقابلـة الثخصـية ، تحليـل الوثنائق ، الاستنبيان ، شـبكة المعلومـات

الدولية كأدوات لجمع البيانات من عينة الدراسة.

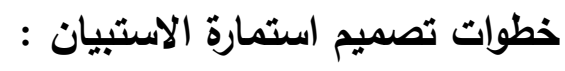
أ- تحديد محاور الإستبيان فى صورتها المبدئية :

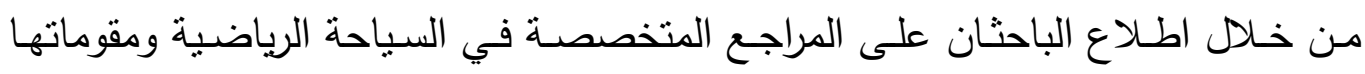

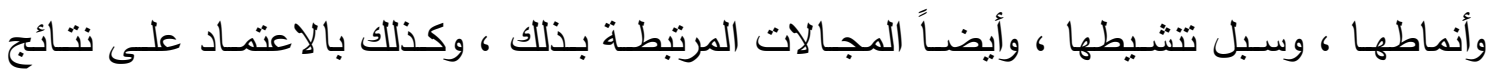
الدراسات والبحوث المرتبطة ، وفى ضوء ونتائج المقابلات الثخصية التي أجراها الباحثان مسبقا

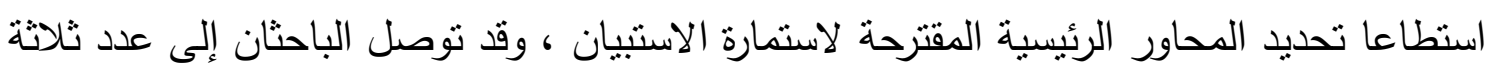
محاور مقترحة يوضحها الجدول التالى:

جدول (r)

توصيف محاور إستمارة الإستبيان فى صورتها المبئية قبل العرض على الخبراء

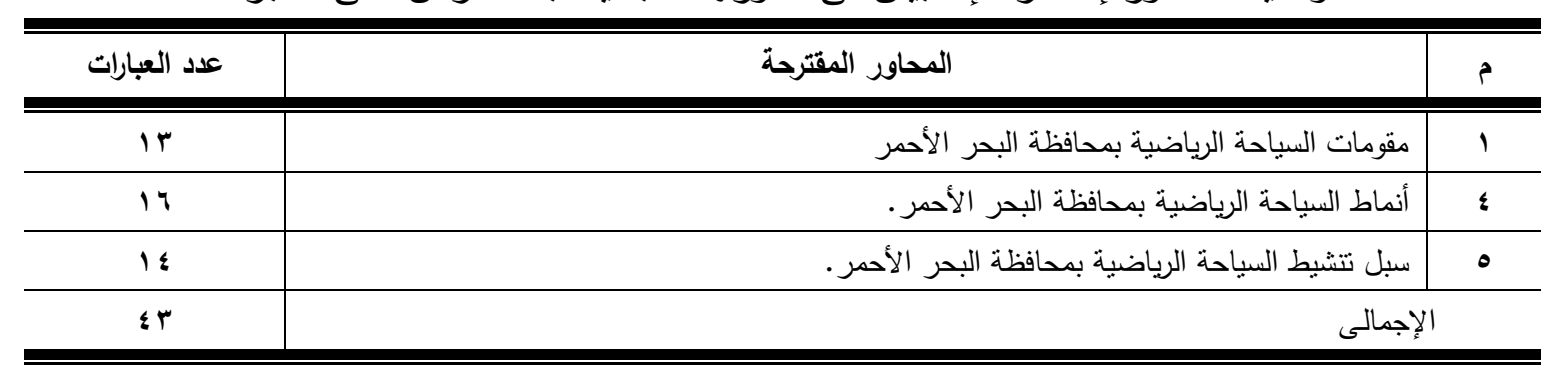

يتضح من جدول (Y) عرض المحاور المقترحة للاستبيان في صورنها المبدئية قبل

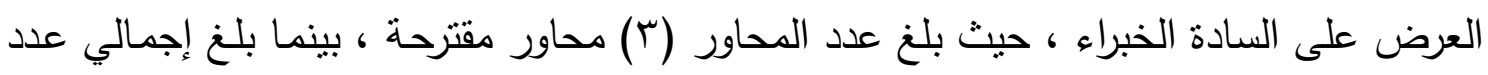

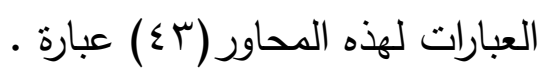

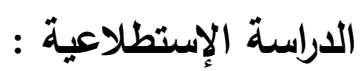

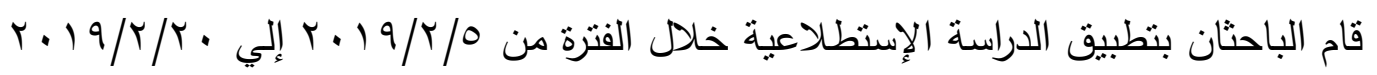

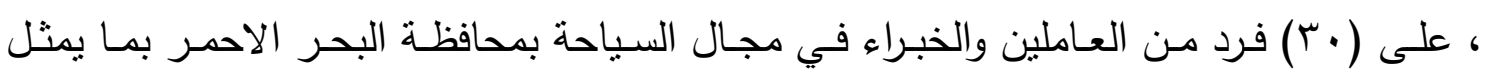
(المديرين بالقرى السياحية بمحافظة البحر الاحمر ، الخبراء فى مجال السياحة ، مسئولى النشاط

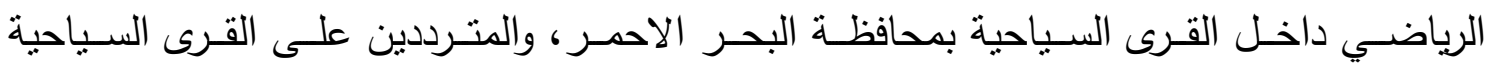

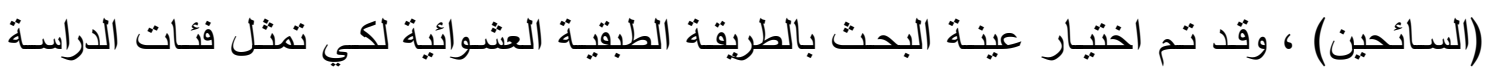




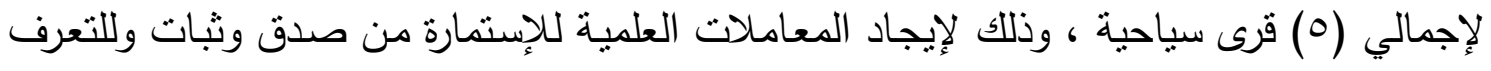

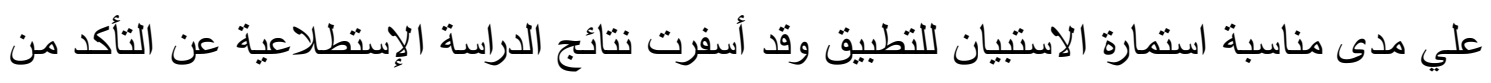
تقنين إستمارة الإستبيان خلال المعاملات العلمية الصدق والثبات.

والجدول التالي يوضح نسبة تمثيل عينة الاراسة الاستطلاعية إلى عينة الدراسة الأساسية .

جدول (r)

نسبة تمثيل عينة الدراسة الاستطلاعية إلى عينة الدراسة الأساسية

\begin{tabular}{|c|c|c|c|c|}
\hline الاستطلاعية تلثيل العينة & الاسينة & الاسينة & فئة العينة & b \\
\hline$\% \leqslant 1.7 \mathrm{~V}$ & 。 & Ir & مديري القرى السياحية المتوفرة فى محافظة البحر الاحمر & -1 \\
\hline$\% \leqslant 1.7 \mathrm{~V}$ & $\bullet$ & ir & خبراء في مجال السياحة & $-r$ \\
\hline$\% 0 \ldots$ & 。 & 1. & مسؤلى النشاط الرياضي داخل القرى السياحية & $-r$ \\
\hline \%rr.vr & 10 & 74 & المترددين على القرى السياحية (السائحين) & $-\varepsilon$ \\
\hline$\% r+.$. & $r$. & $1 \ldots$ & 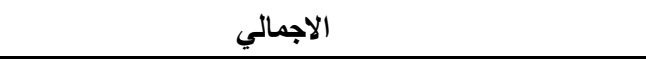 & \\
\hline
\end{tabular}

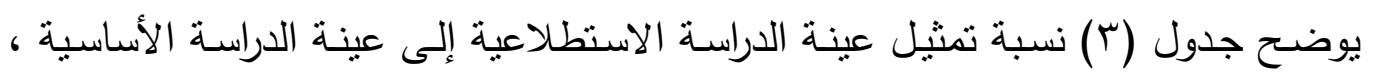

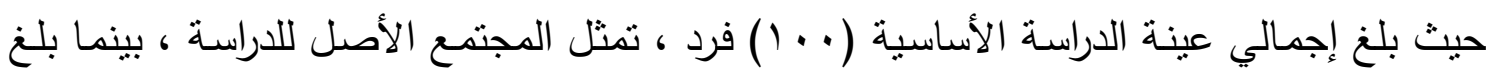

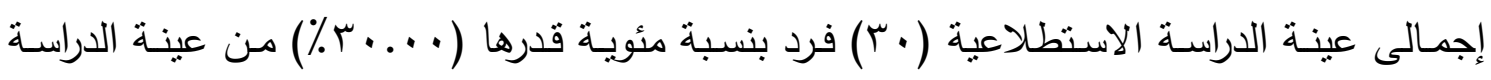
الأساسية ومن خارج العينة الأساسية.

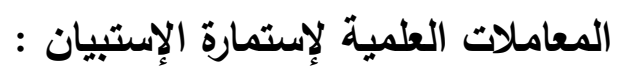
صدق الاستمارة : تم حساب صدق الاستمارة بطريقتين:

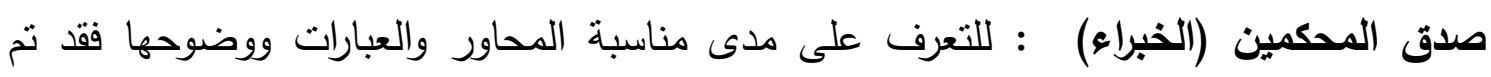

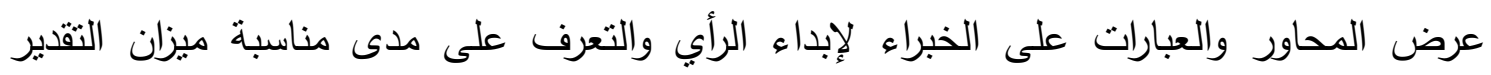

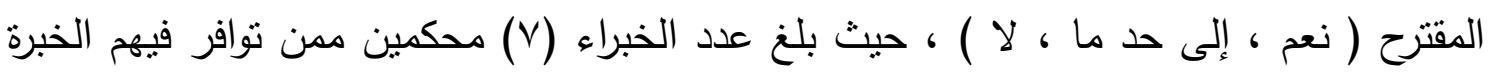

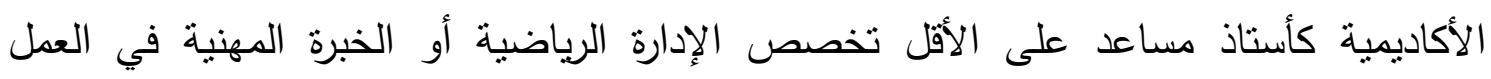

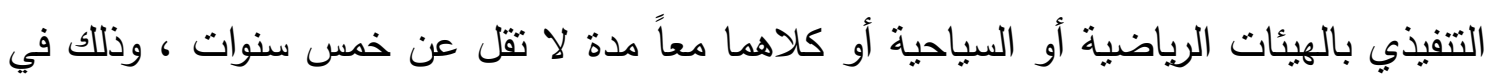

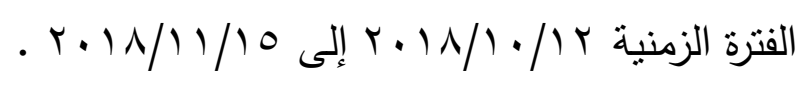


جدول (๕)

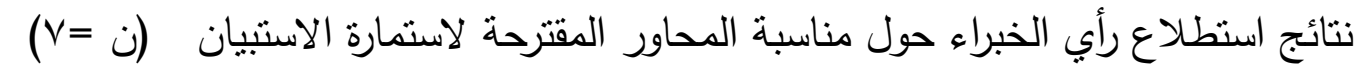

\begin{tabular}{|c|c|c|c|c|c|c|}
\hline 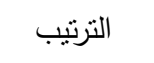 & الأهمية النسبية & 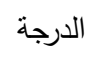 & غير مناسب & 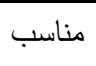 & المحاور المقترحة & s \\
\hline 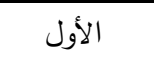 & $\% 1 \ldots$ & $v$ & - & $\checkmark$ & مقومات السياحة الرياضية بمحافظة البحر الأحمر & 1 \\
\hline 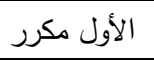 & $\% 1 \ldots$ & V & - & V & أنماط السياحة الرياضية بمحافظة البحر الأحمر . & r \\
\hline الأول مكرر & $\% 1 \ldots$ & $v$ & - & V & سبل نتشيط السياحة الرياضية بمحافظة البحر الأحمر . & $r$ \\
\hline
\end{tabular}

يوضح جدول (§) اتفاق آراء السادة الخبراء على جميع المحاور المقترحة لاستمارة الاستبيان.

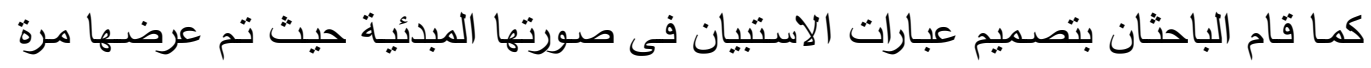

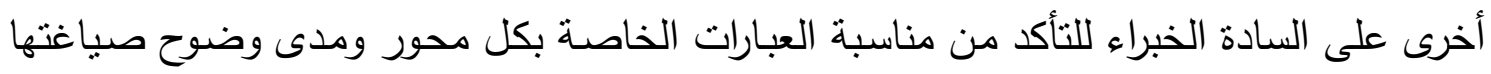

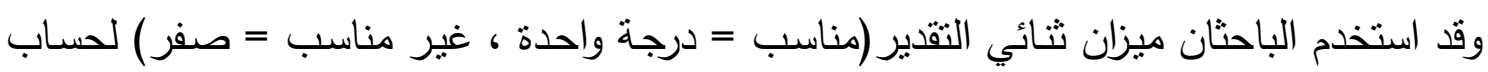

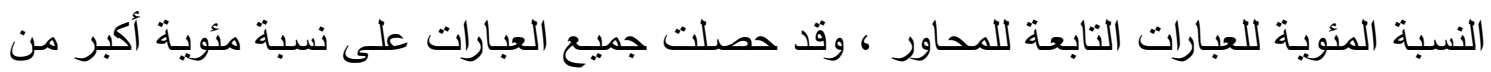

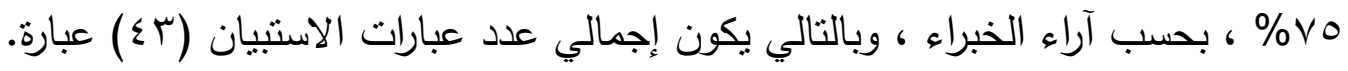
صدق الإتساق الداخلى

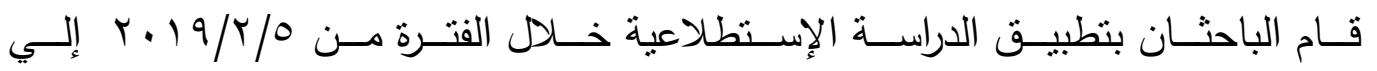

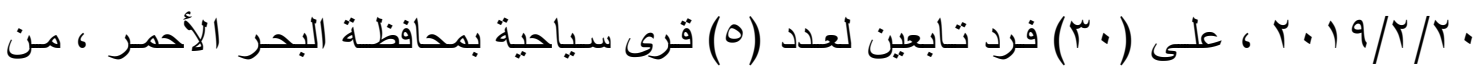

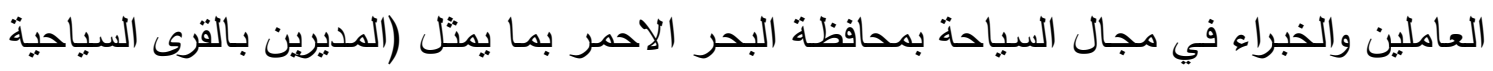

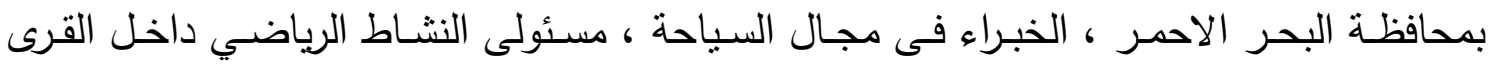

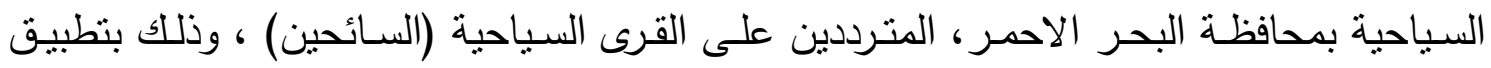

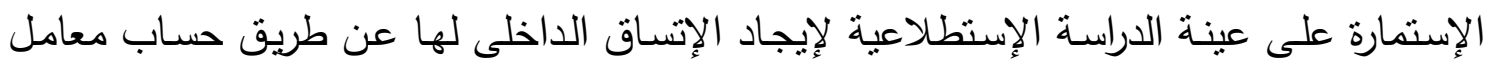
الارتباط بين كل عبارة ومجموع درجات المحور المنتمية إليه.

\section{تطبيق الاستمارة قيد البحث وإعادة التطبيق:}

قام الباحثان بحسـاب معامل الثبات بتطبيق الإختبار وإعادة تطبيقهـ بفاصل زمنس قدرة

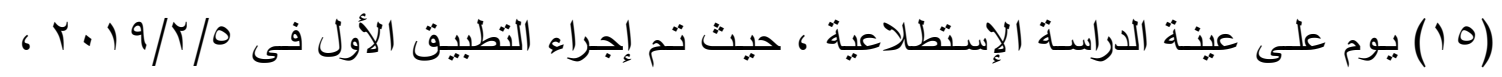

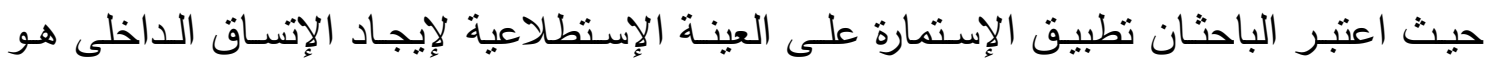

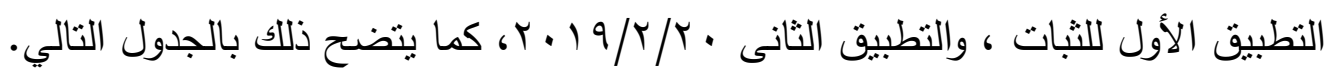


جدول (0)

قيم معاملات صدق الاتساق الداخلى ومعامل الثبات لعبارات محاور الاستبيان (ن = •r)

\begin{tabular}{|c|c|c|c|c|c|c|c|c|c|c|c|c|c|}
\hline \multirow{3}{*}{ معامل ارتباط } & \multicolumn{2}{|c|}{ التطبيق الثانى } & \multirow{3}{*}{ الاتساق } & \multirow{2}{*}{\multicolumn{2}{|c|}{ التطبيق الأول }} & \multirow{3}{*}{ العبارة } & \multirow{3}{*}{ معامل ارتباط } & \multirow{2}{*}{\multicolumn{2}{|c|}{ التطبيق الثانى }} & \multirow{3}{*}{ الاتساق صدق } & \multicolumn{2}{|c|}{ التطبيق الأول } & \multirow{3}{*}{ العبارة } \\
\hline & \multirow{2}{*}{$\varepsilon$} & \multirow[b]{2}{*}{ P } & & & & & & & & & & & \\
\hline & & & & $\varepsilon$ & a & & & $\varepsilon$ & م & & $\varepsilon$ & p & \\
\hline$* . v 11$ & .04 & Y.TV & $* v \vee r$ & . ITY & $r .0 \leq r$ & rr & $* . \wedge .0$ & $\rightarrow v i v$ & r.sir & $* . \wedge \ldots$ &. .701 & r.OYY & 1 \\
\hline *.VYY & $.7 . \varepsilon$ & r.Tor & $* . .799$ &. .701 & r.०.. & $r \varepsilon$ & $* . . T V T$ & $.7 r$. & Y.070 & $* .00$ &. .700 & r.070 & $r$ \\
\hline$* . \vee v \leq 4$ & .010 & $r .0 \leq r$ & $* . . \vee 0 \leqslant$ &. $.0 V Y$ & r.tr. & ro & $* . .71 r$ & . & $Y . \leqslant \vee \wedge$ & $* . v i v$ & . Orr & r.qr. & $r$ \\
\hline$* . \wedge \cdot \varepsilon$ &. $.0 \wedge r$ & r.oro & $* . v r V$ & . .TYY & $r .0 \leqslant r$ & r & $* \cdot . \wedge \cdot 4$ & $.7 r \Lambda$ & Y.797 & $* . . \wedge 9 \%$ & $\because \vee 0$. & $r . \varepsilon r_{0}$ & $\varepsilon$ \\
\hline$* . \vee V \wedge r$ &..$\leqslant 91$ & r.vrq & $* . \wedge .1$ & .01 & Y.०AV & rV & $* \cdot . \wedge \cdot r$ & צ & T.rYt & $* . .4 \wedge 1$ &. .791 & 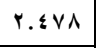 & 0 \\
\hline$* . .0 \mathrm{Vr}$ & $\cdot .7 \cdot 1$ & Y.rYT & $* . . \vee 4$ &. .791 & r.०.. & rA & $* . \wedge \wedge r$ & . & Y.T. & $* . \wedge 1 \wedge$ & . VYr & 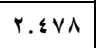 & 7 \\
\hline$* .01 r$ & $.70 \mathrm{~V}$ & $r .0 \leq r$ & $* . \vee v r \Lambda$ & - . Tr & $r . \Delta \leq r$ & rq & $* .710$ & . & r.vTI & $* .07 \mathrm{~V}$ & $0.0 \leq 1$ & r.०AV & $v$ \\
\hline$* . .741$ & $.7 . \varepsilon$ & $r .0 \leqslant \Lambda$ & *..०r & .014 & r.OYY & $r$. & $* . \wedge r q$ &..$\leqslant 94$ & 9.7.9 & $* . .7 \leqslant 1$ &. $.7 \wedge \Lambda$ & r.\&ro & $\wedge$ \\
\hline$* . v \ldots$ & .010 & $r .004$ & $* .7 \leqslant 0$ & $.7 r \leq$ & Y.0. & $r 1$ & $* . A r \varepsilon$ & $.70 \mathrm{~V}$ & $r .0 \leqslant r$ & $* . \Delta r_{0}$ & . vv . & r.r.9 & 9 \\
\hline$* . .414$ & $.0 \wedge r$ & r.stro & $* . .7 \vee \wedge$ & .014 & r.OYY & rY & $* \cdot . \wedge \cdot 1$ & . Trr & $r .0 \leq r$ & $* . \wedge .1$ &. .791 & r.o.. & 1. \\
\hline$* . \vee \vee \wedge 0$ & . . & $r . \vee \vee \wedge$ & 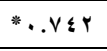 &. .701 & $r . \leqslant \vee \wedge$ & rr & $* . . \vee \backslash \wedge$ & $.7 \leq 9$ & r.rq1 & $* . . v \ldots$ & $\because \leqslant q \wedge$ & r.०AV & 11 \\
\hline$* . .700$ & $.0 \leq \leqslant$ & Y.070 & $* . . \Delta \wedge 4$ & ב & r.orr & $r \varepsilon$ & $* . \wedge \wedge r$ & $\cdot . \Lambda \cdot v$ & r. $\leqslant$ T & $*$. * V० & .79 & $r .0 \leq r$ & ir \\
\hline$* . v 11$ & .7 .0 & r.orr & $* .0 \leqslant V$ & $.0 \wedge r$ & r.070 & ro & $* . .07 \varepsilon$ & .901 & Y.०.. & $* .04 Y$ & .701 & r.orr & ir \\
\hline$* v \cdot v \cdot v$ & $.0 \leq 4$ & Y.\&0Y & $* \cdot .4 \cdot r$ & $.70 \mathrm{~V}$ & r.\&०Y & $r 4$ & $* . \vee V r q$ & $.0 \wedge 0$ & $r .0 \leq r$ & $* v \vee v \leqslant 0$ & . . & r.4. & $1 \varepsilon$ \\
\hline$* . v \cdot 0$ & .0 .0 & r.orr & • . . . & צזTו. & Y.01؛ & $r v$ & $*$ *. . \& & $\cdots \leqslant q 1$ & r.vrq & $* . \vee \vee ५$ &.$\quad .7 \%$. & r.070 & 10 \\
\hline$*$ *.VAr & .101 & r.o.. & $* . . V \leq 0$ &. .791 & Y. $\leqslant \vee \wedge$ & $r \Lambda$ & $* . . \vee a r$ & .700 & r.070 & *.. vo & .700 & r.070 & 17 \\
\hline$* .04 \varepsilon$ & .711 & r.०Ar & $* . \wedge \leq$ & .7 .0 & Y.s & $r q$ & $* . . \vee r q$ & . TYY & $r . T \leq r$ & $* \cdot v \cdot v$ & $.70 \mathrm{~V}$ & $r .0 \leq r$ & IV \\
\hline$* . .09 \mathrm{~V}$ & $.0 \wedge 0$ & Y.O. & "... & . . Tr. & Y.070 & $\varepsilon$ & $* . \vee \vee 4$. & $.71 \mathrm{~V}$ & r.sir & $* . \vee \vee V r$ & .viv & $r . \leqslant 1 T$ & 11 \\
\hline$* . \wedge 1 \%$ & $.71 \mathrm{~V}$ & $r . \varepsilon / r$ & $* . \vee \vee \varepsilon$ & TrT & r.OYY & «1 & $* . . \vee \vee \wedge$ & . TrY & r.O & $* . \wedge \leq 4$ &. .791 & $r . \leqslant \vee \wedge$ & 19 \\
\hline$* . \wedge \%$ & $\Rightarrow 7 \leq$. & $r .7 \leqslant \Lambda$ & $* . \vee \vee q$, &.$\neg \wedge \wedge$ & $r . \leqslant r_{0}$ & $\leqslant r$ & *..vor & .0 .0 & r.VYr & $* v \vee V$ &..$\Delta \wedge$. & Y.OAV & $r$. \\
\hline$* . \wedge \vee r$ & . Tor & r.०AV & $* . \wedge .9$ & .79 & Y. $\leqslant 04$ & \& & *..V14 & $\cdots \leqslant \wedge 1$ & r.Yor & *. .VrI &.$\Delta \wedge r$ & r.040 & rl \\
\hline & & & & & & & $* . \wedge 1$ & $\rightarrow V \leq 0$ & r.rq। & $* .79 \varepsilon$ & . & r.0Yo & rr \\
\hline
\end{tabular}

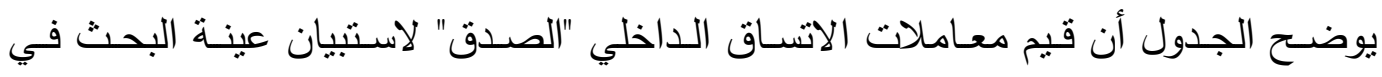

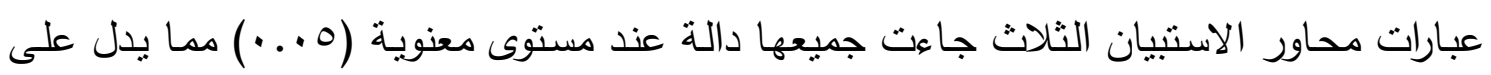

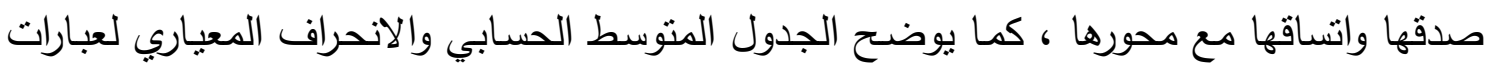

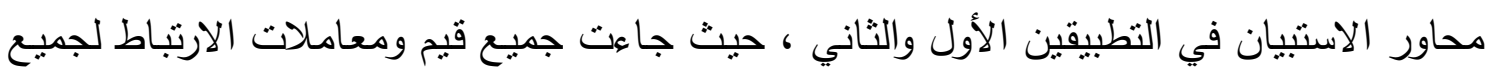

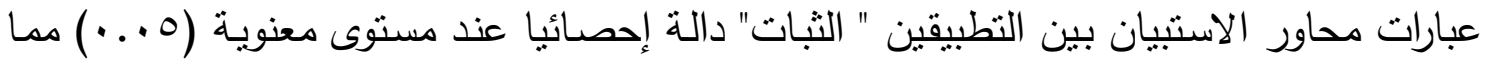
يدل على ثباتها ، وبذلك يكون عدد عبارات محاور الاستبيان (r ع) عبارة . 
جدول (7)

معاملات الصدق والثبات لمحاور الاستبيان (ن = •r؟)

\begin{tabular}{|c|c|c|c|c|c|c|c|c|}
\hline \multirow{2}{*}{ معامل الثبات } & \multicolumn{2}{|c|}{ التطبيق الثانى } & \multirow{2}{*}{ الصدق } & \multicolumn{2}{|c|}{ التطبيق الأول } & \multirow{2}{*}{ |لعبارات } & \multirow[b]{2}{*}{ محاور الاستبيان } & \\
\hline & $\varepsilon$ & م & & $\varepsilon$ & م & & & a \\
\hline$* . \vee \vee \diamond$ & $\Lambda .097$ & r..०Y & $*$.. Av & $9.1 \%$. & ro... & $1 \varepsilon$ & مقومات السياحة الرياضية بمحافظة البحر الأحمر & 1 \\
\hline$* . . \wedge \leqslant 9$ & $\wedge .0 \wedge 0$ & $\leqslant 0 . \wedge 1 \varepsilon$ & $* . \wedge \%$ & 11.114 & $\leqslant$ «. $9 \vee 9$ & IV & أنماط السياحة الرياضية بمحافظة البحر الأحمر. & r \\
\hline *..人40 & 1.19. & rq.vץ. & 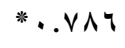 & q.. vo & . . & 10 & سبل نتشيط السياحة الرياضية بمحافظة البحر الأحمر . & $r$ \\
\hline
\end{tabular}

يوضتح جدول (؟) المتوسط الحسابي والانحراف المعياري لمحاور الاسنبيان عينة الدراسة

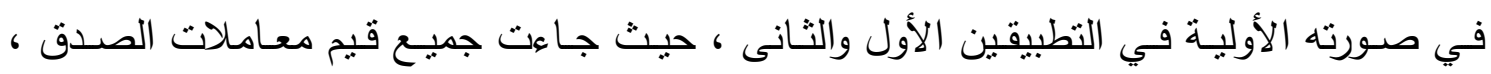

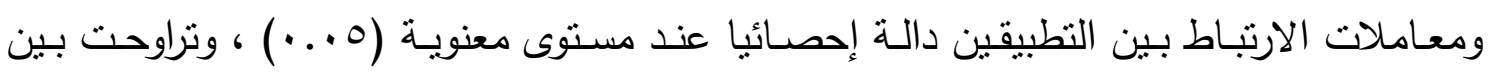

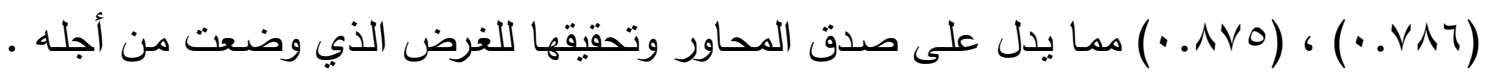

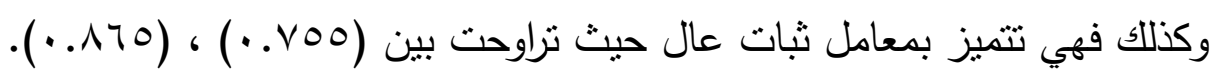

إيجاد معامل الفا كرونباخ

للتحقق من مدى ثبات الاستبيان استخدمت الباحثان طريقة الفا كرونباخ لتحديد معامل

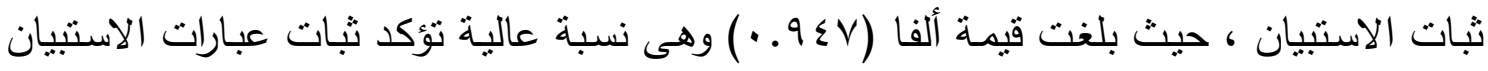

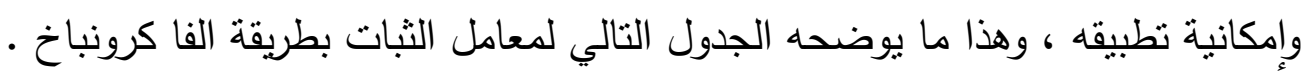

$$
\text { جدول (v) }
$$

معامل ثبات الاستنيان بطريقة الفا لكرونباخ

\begin{tabular}{|c|c|c|c|}
\hline قيمة الفا & الانحراف المعياري & المتوسط الحسابي & البيان الإحصائي \\
\hline$* . .9 \leq V$ & or.vi. & $r .0 . .$. & المجموع الكلى \\
\hline
\end{tabular}

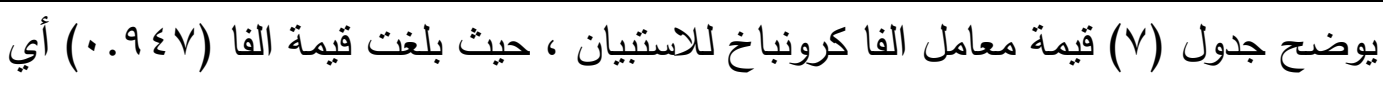
أنها نسبة عالية تؤكد امكانية استخدام الاستيان .

الاراسة الأساسية :

قام الباحثان بتطبيق استمارة الاستبيان فى صورتها النهائية على عينـة والذين بلغن عددهم

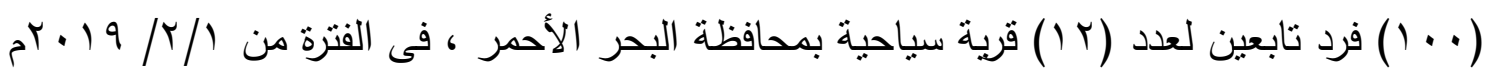

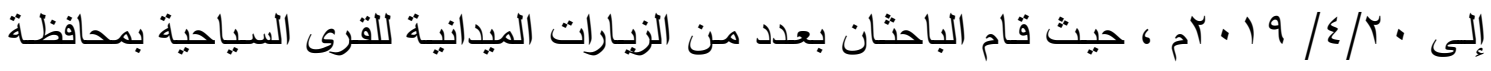

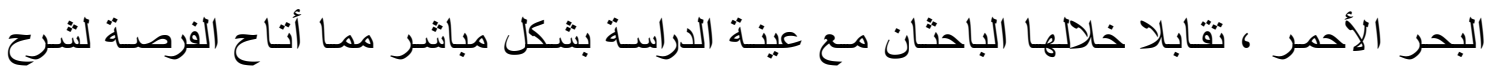

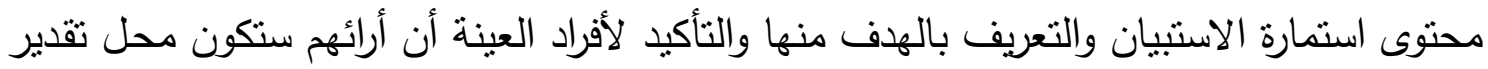


وسرية وان لهم مطلق الحرية للتعبير عن ارائهم بصراحة تامة وان هذه الآراء لن تستخدم إلا في

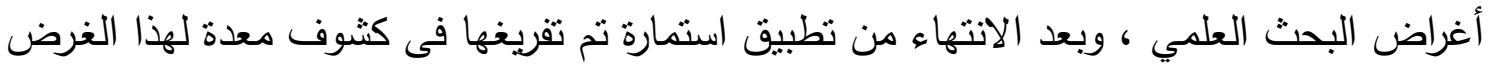

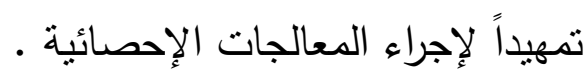

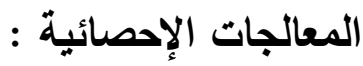

النسبة المئوية ، معامل الارتباط ، معامل الفا لكرونباخ ، المتوسط الحسابي ، الانحراف المعياري.

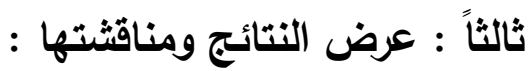
قام الباحثان بعرض نتائج البحث التي تم التوصل إلبها تبعاً لترتيب المحاور من خلال

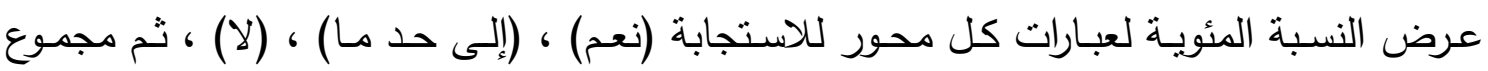

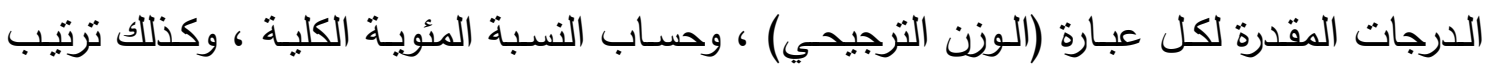
العبارات وفقاً للنسبة المئوية الكلية . وفيما يلي عرض ومناقشة نتائج تساؤل الدراسة : ما هي سبل تنشيط السياحة الرياضية ومقوماتها وانماطها المناسبة بمحافظة البحر الأحمر؟ 
1- بالنسبة لمحور مقومات السياحة الرياضية بمحافظة البحر الأحمر:

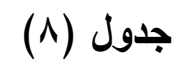

النسب المئوية والتكرارات لاستجابات عبنة الدراسة في عبارات

المحور الأول : مقومات السياحة الرياضية بمحافظة البحر الأحمر ( ن = . . 1 )

\begin{tabular}{|c|c|c|c|c|c|c|c|c|c|c|}
\hline \multirow{2}{*}{ الترتيب } & \multirow{2}{*}{ النئة - النسية } & \multirow{2}{*}{ 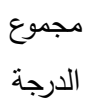 } & \multicolumn{2}{|c|}{ ע } & \multicolumn{2}{|c|}{ إلى حد ما } & \multicolumn{2}{|c|}{ نعم } & \multirow{2}{*}{ العبـــــــــــارة } & \multirow{2}{*}{ s } \\
\hline & & & $\%$ & 5] & $\%$ & ك & $\%$ & 5] & & \\
\hline$\circ$ & $\wedge \vee \ldots$ & rTl & ir & ir & 10 & 10 & $v r$ & $v r$ & تمالية ـ محافظة البحر الأحمر شواطئ سياحية ذات جودة & 1 \\
\hline r & $9 . .7 \mathrm{~V}$ & TVt & 9 & 9 & $1 \cdot$ & 1 . & $\wedge$ & 八) & توجد قاعات للمؤتمرات مجهزة بأحدث التكنولوجيا العالمية & r \\
\hline V & Mr. & $r \leq \varepsilon$ & r. & r. & 17 & 17 & $7 \varepsilon$ & $7 \varepsilon$ & دول الاتحاد الأوربي سياحيا. البحر الأحمر بالإقبال الكبير من قبل & r \\
\hline 11 & ro.r & TrY & rV & tr & r. & r. & or & or & تمنتلك محافظة البحر الأحمر ملاعب شاطئية في مختلف & $\varepsilon$ \\
\hline$\varepsilon$ & $\wedge \wedge .7 \vee$ & หчצ & 9 & 9 & 17 & 17 & vo & vo & تمنل رياضة الصيد نشاطاً سياحياً بمحافظة البحر & 0 \\
\hline r & $91 \ldots$ & rVT & $1 \cdot$ & $1 \cdot$ & V & $\checkmark$ & N & ה & توافر العمالة السياحية المدربة بالمنشآت السياحية & 7 \\
\hline 1 & T4.r & r^৭ & . & • & 11 & 11 & 19 & $\wedge 9$ & 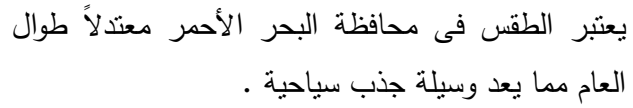 & V \\
\hline ir & $v \varepsilon \ldots$ & rrt & $r \varepsilon$ & $r \varepsilon$ & $1 \cdot$ & 1 . & 07 & 07 & تهتم هيئة تتشيط السياحة بالمحافظة بالسياحة الرياضية . & $\wedge$ \\
\hline 1 & $\wedge \varepsilon \ldots$ & ror & $1 \cdot$ & $1 \cdot$ & rᄉ & rᄉ & Tr & Tr & الأحمر . & 9 \\
\hline 9 & vq... & tri & $1 \varepsilon$ & $1 \varepsilon$ & ro & ro & 01 & 01 & 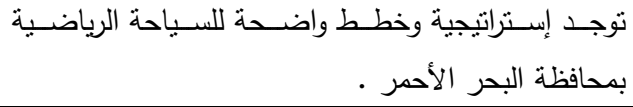 & $1 \cdot$ \\
\hline $1 \cdot$ & Tu.r & rrq & 17 & 17 & rq & rq & $\leqslant 0$ & $\leq 0$ & 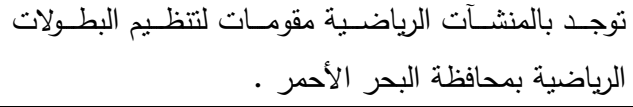 & 11 \\
\hline ir & $T V . .$. & $r \cdot 1$ & $\varepsilon \varepsilon$ & $\varepsilon \varepsilon$ & ry & ry & ro & ro & 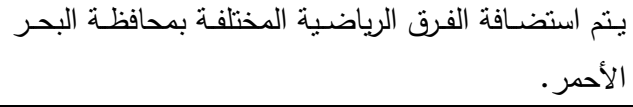 & ir \\
\hline$\wedge$ & $\wedge . .$. & $r \leq$. & Ir & ir & דץ & דr & Or & or & تالرياضية للسائحين الفنـادق والمنشــآت الســياحية بإقامـة المهرجانــات & Ir \\
\hline
\end{tabular}

يتضح من جدول (^) التكرارات والنسب المئوية لاستجابات عينة الدراسة من( مديري القرى

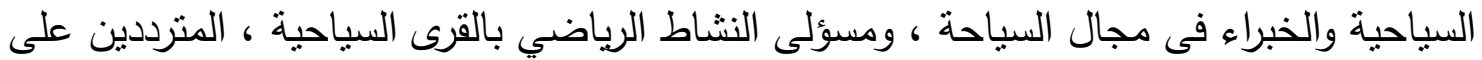
القرى السياحية بمحافظة البحر الاحمر) في عبارات المحور الأول : مقومـات السياحة الرياضية باهية

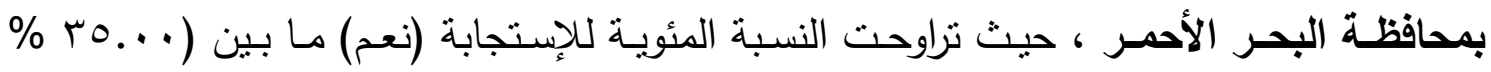

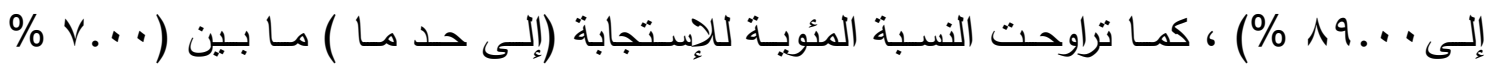

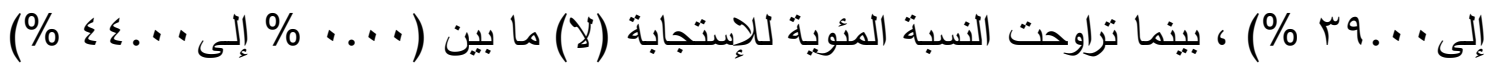


، وجاءت النسبة المئويـة الكلية لمجموع الدرجات المقدرة لكل عبارة في استجابات العينة ما بين

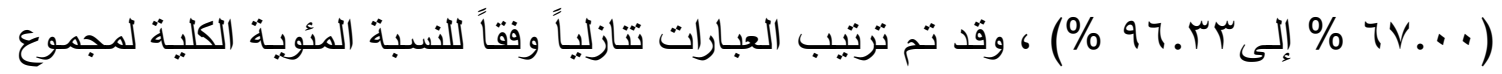
الدرجات المقدرة لكل عبارة في استجابات العينة موضحة "مقومـات السياحة الرياضية بمحافظة البحر الأحمر: - (البات

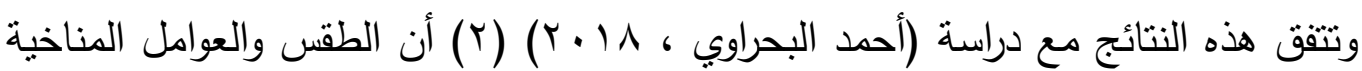

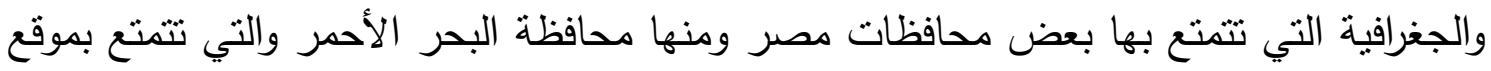
جغرافي متميز ومناخ معتدل لممارسة العديد من الأنشطة الرياضية المختلفويساعدها ذلك كوسيلة جذب للسياح يجعلها تتميز عن غيرها من الأماكن ، والتي تتمثل في تتظيم المسابقات الرياضية التئية

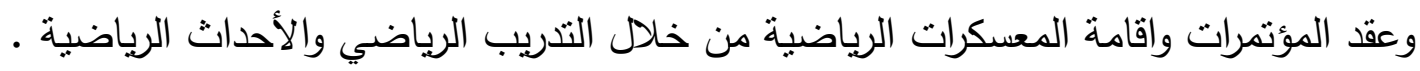

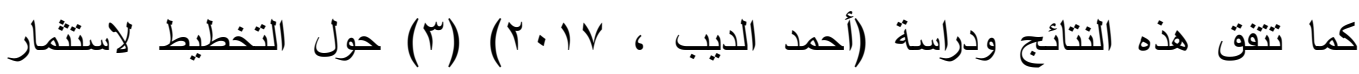

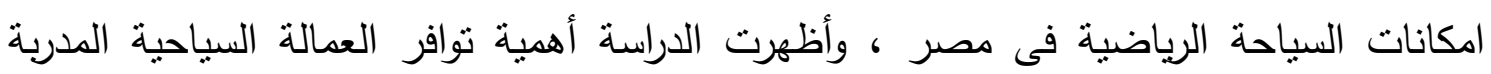

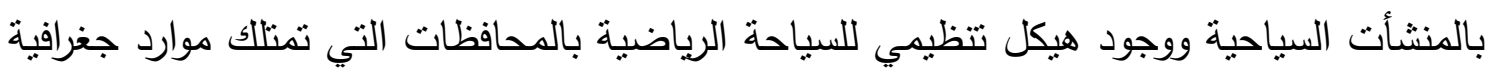

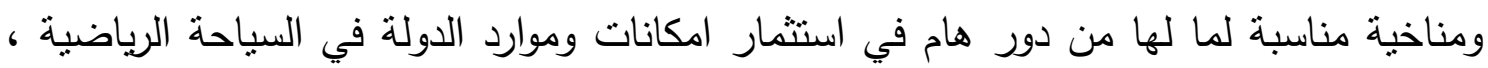
كما أنثارت نتائج "الديب" إلى أهية وجود استراتيجية وخطط واضحة للسياحة الرياضية في محافظات مصر السياحية ، ومنها البحر الأحمر.

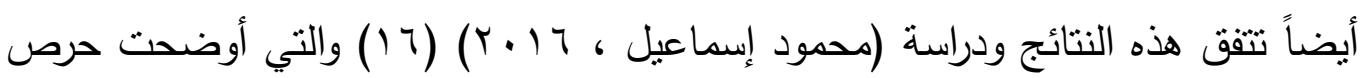

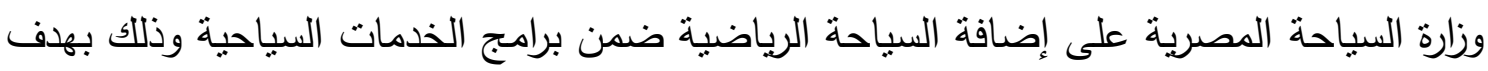

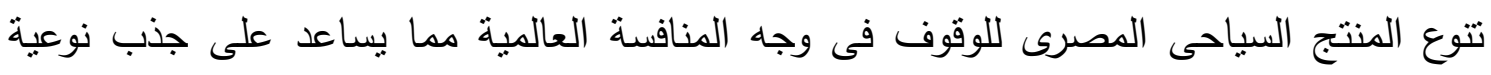

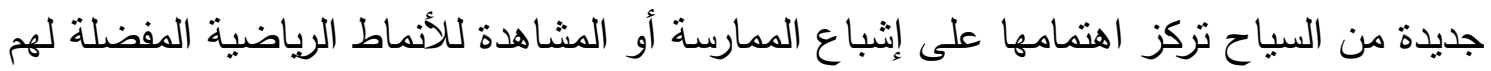

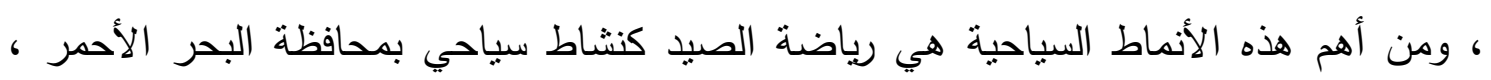

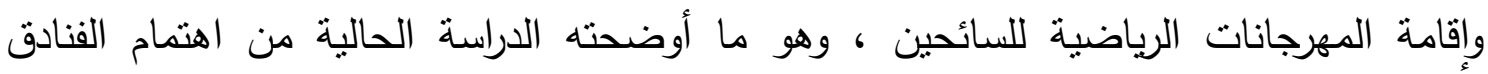
والمنشأت السياحية بإقامة المهرجانات الرياضية للسائحين.

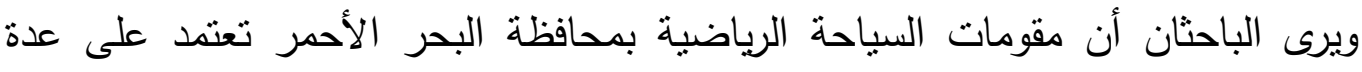

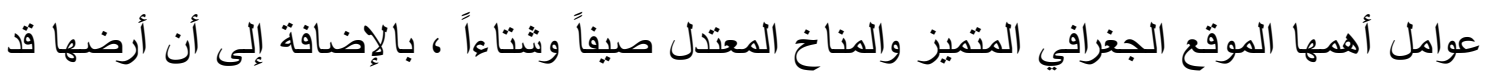

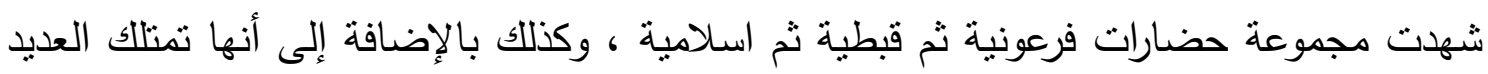

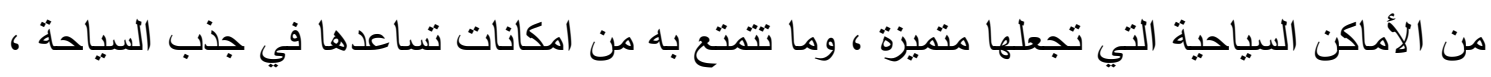

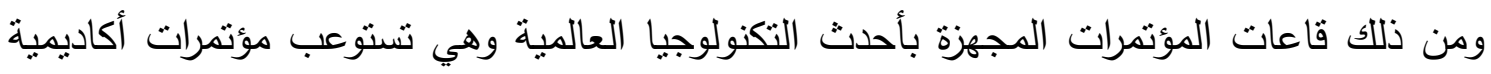

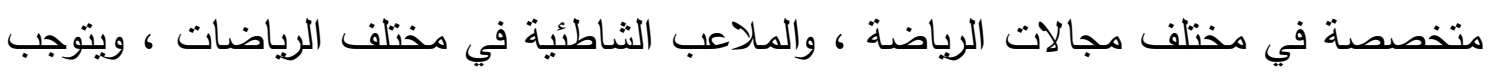


زيادة فرص استضافة المهرجانات الرياضية واستضافة الفرق الرياضية المختلفة للمعكرات أو

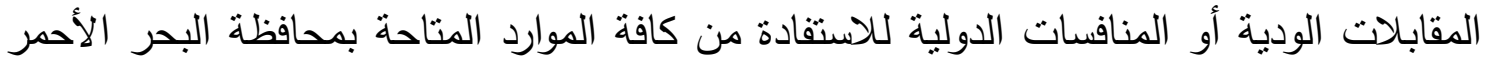

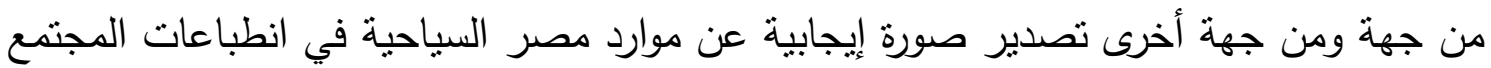
الدولي دعماً لمزيد من استقبال الأفواج السياحية.

جدول (9)

المتوسط الحسابي والإنحراف المعياري ومعامل الإلنواء لعبارات

المحور الأول : مقومات السياحة الرياضية بمحافظة البحر الأحمر (ن = . . ( )

\begin{tabular}{|c|c|c|c|c|c|c|c|c|c|c|c|c|c|}
\hline \multicolumn{3}{|c|}{ 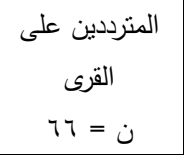 } & \multicolumn{3}{|c|}{ 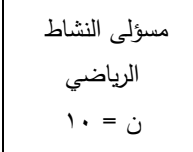 } & \multicolumn{3}{|c|}{ 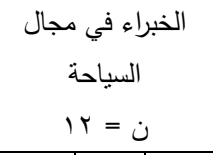 } & \multicolumn{3}{|c|}{ مديري القرى } & \multirow[t]{2}{*}{ العبـــــــــارة } & \\
\hline J & $\varepsilon$ & 5 & J & $\varepsilon$ & 5 & J & $\varepsilon$ & م & J & $\varepsilon$ & 5 & & \\
\hline $\begin{array}{ll}- \\
. \\
.\end{array}$ &. .74 & T.M. & 1.v৯- & $\quad \cdots \leqslant r$ & r.A. &..$\leq \leqslant-$ & .70 & T.TH & r..o- & ה . . & r.Ar & تمتلك محافظة البحر الأحمر شواطئ سياحية ذات جودة عالية & \\
\hline $\begin{array}{l}- \\
-94 \\
\end{array}$ & .74 & Y. $\leqslant \wedge$ & $1 . \vee \lambda-$ & $\quad . \leqslant r$ & r.A. & $1 . . v-$ & .70 & r.o. & r...o- &.$r q$ & r.Ar & توجد قاعات للمؤتمرات مجهزة بأحدث التكنولوجيا العالمية . & 1 \\
\hline $\begin{array}{l}- \\
\cdot .9 \vee\end{array}$ & $.7 \leqslant$ & r.01 & $1.11-$ & $\cdot . v 1$ & r.o. & $1 . . v-$ & . & r.o. & r..o- &.$r 9$ & Y.Ar & الاتحاد الأوربي محافظة البحر الأحمر بالإقبال الكبير من قبل دول & r \\
\hline $\begin{array}{c}- \\
. .9 \Lambda\end{array}$ & - & Y.०. & $1 . .5-$ & $\because$. & r.v. & $1 . . v-$ &..$T V$ & r.o. & 1.rT- & $\therefore \leqslant 0$ & r.vo & |لرياضيات محافظة البحر الأحمر ملاعب شاطئية في مختلف & $\varepsilon$ \\
\hline $\begin{array}{l}- \\
.99\end{array}$ & $.7 \leqslant$ & r.o. & $1 . . r-$ & $\because$. & r.v. & $1 . . v-$ &. $.7 V$ & r.o. & - וזr. & $\therefore \leqslant 0$ & r.vo & تمتل رياضة الصيد نشاطاً سياحياً بمحافظة البحر الأحمر . & 。 \\
\hline . .70 & . $\leqslant 1$ & Y. . . & $1 . . r-$ & $\quad . \leqslant \wedge$ & r.v. & $. . \mathrm{Vr}-$ &.$T V$ & r.\&1 & r...o- &.$r q$ & r.Ar & توافر العمالة السياحية المدربة بالمنشآت السياحية & 7 \\
\hline $\begin{array}{l}- \\
-.9 r \\
\end{array}$ &. .77 & r. & $1 . \vee \lambda-$ & O & r.A. & $1 . . v-$ &. $.7 \mathrm{~V}$ & r.o. & r... &. .49 & r.Ar & 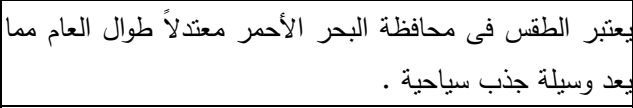 & $\checkmark$ \\
\hline $\begin{array}{ll}- \\
. \mu \nu\end{array}$ & .0. & r.OV & $1 . \vee \lambda-$ & $\cdot \ldots r$ & r.A. & $. r q-$ &. .01 & r.01 & r...o- &. .49 & r.Ar & تهتم هيئة تتشيط السياحة بالمحافظة بالسياحة الرياضية . & $\wedge$ \\
\hline $\begin{array}{c}- \\
.+1 \mathrm{~V} \\
\end{array}$ & $.7 \cdot$ & T.YV & $\cdot \vee \vee \lambda-$ & $\because v$. & r.ః. & $. .1 \mathrm{~V}-$ & r. & T.YO & I.Tr- & $\therefore \leqslant 0$ & r.vo & يوجد هيكل تتظيمي للسياحة الرياضية بمحافظة البحر الأحمر . & 9 \\
\hline $\begin{array}{c}- \\
\cdots, \mathrm{V}\end{array}$ & .7. & T. TV & $\cdot . \leqslant \wedge-$ & .04 & r.. & $. .1 \vee-$ &..$T r$ & r. ro & $.49-$ &. .01 & r.01 & توجد إستراتيجية وخطط واضحة للسياحة الرياضية بمحافظة & \\
\hline \begin{tabular}{c|}
- \\
$-.4 \varepsilon$
\end{tabular} & $\therefore$ vo & T. TH & $1 . \vee \lambda-$ & $\cdot \ldots r$ & r.A. & $. . \mathrm{Yr}-$ & $\therefore$. A & r.ru & $\cdot . \wedge 1-$ & $\cdot . \leqslant 9$ & r.74 & بمحافظة البحر الأحمر بآرياض الرية مقومات لتنظيم البطولات الرياضية & \\
\hline $\begin{array}{l}- \\
\cdots 1 v \\
\end{array}$ & .71 & r. r $\leqslant$ & $1.77-$ & $\because v$. & r.7. & $\because v^{\prime}$ & זT. & r.ro & $\cdot . \wedge 1-$ & $\therefore \leqslant 9$ & | & يتم استضافة الفرق الرياضية المختلفة بمحافظة البحر الأحمر. & \\
\hline \begin{tabular}{c|c}
- \\
$\cdot . r \varepsilon$
\end{tabular} & $\cdot . \wedge$. & r.1A & $1 . . r-$ & $\cdot . \leqslant \wedge$ & r.V. & .ro- & 畒. & $r .17$ & $\cdot v r-$ & $.0 Y$ & r.o. & |للسائحين الفنادق والمنشآت السياحية بإقامة المهرجانات الرياضية & \\
\hline
\end{tabular}

يتضح من جدول (9) استجابات فئات العينة علي عبارات المحور الأول : مقومات السياحة الرياضية بمحافظة البحر الأحمر ، حيث جاءت استجابات (مديري القرى السياحية بمحافظة البحر

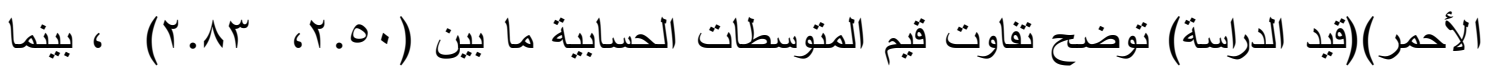




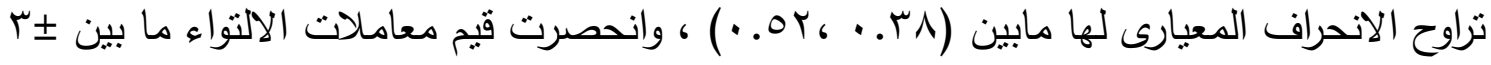

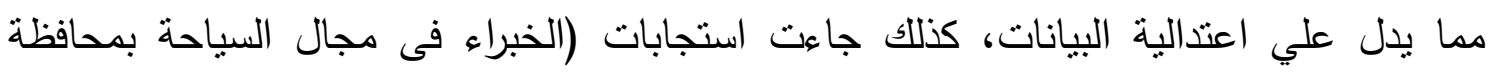

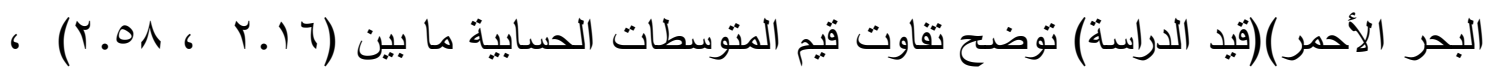

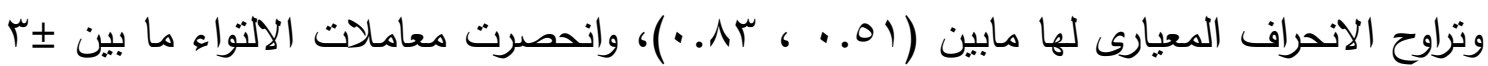
مما يدل علي اعتدالية البيانات ، ايضا جاءت استجابات (مسؤلى النشاط الرياضي ببعض القرى

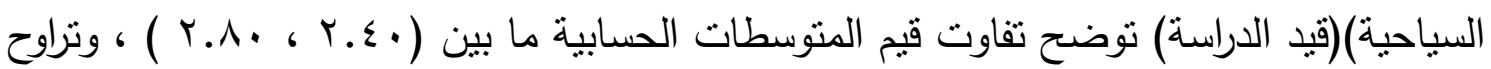

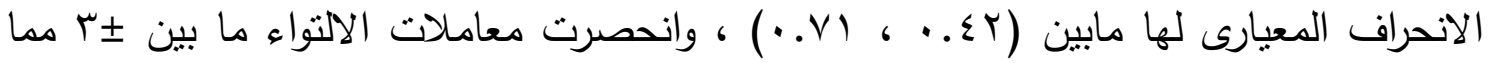
يدل علي اعتدالية البيانات ، في حين جاءت استجابات (المترددين على القرى السياحية بمحافظة

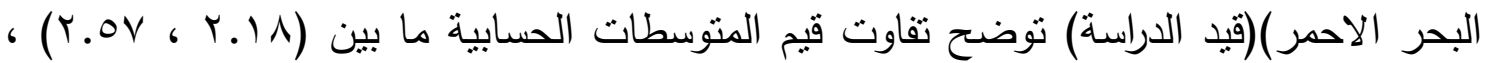

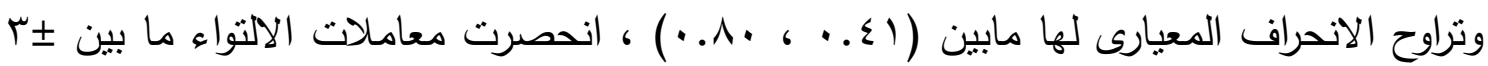
مما يدل علي اعتدالية البيانات. كما تثير نتائج الجدول حول محور (مقومات السياحة الرياضية بمحافظة البحر الأحمر) أن أن النيان

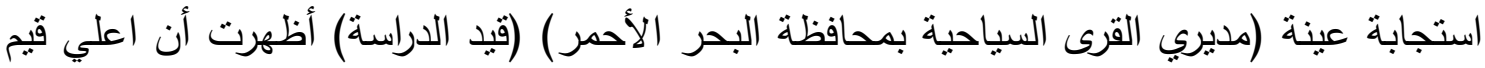

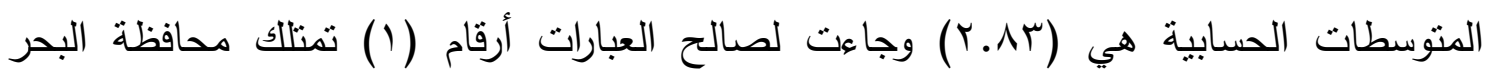

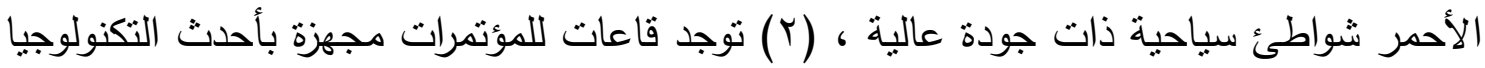

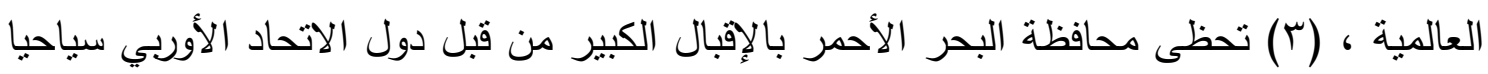

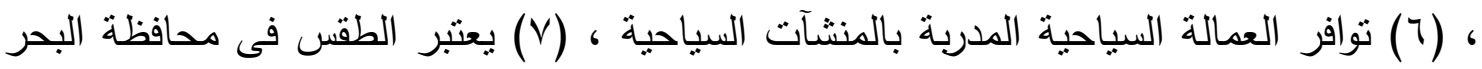

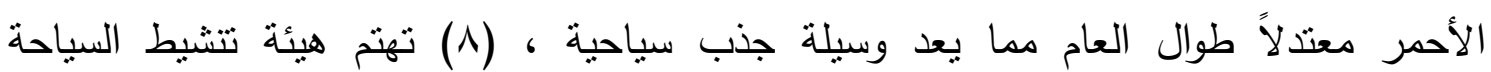

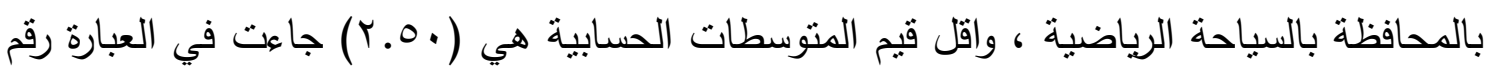

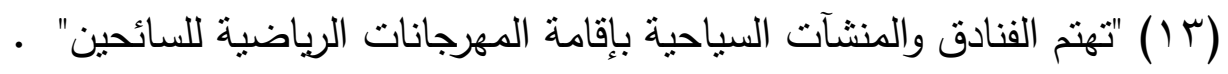

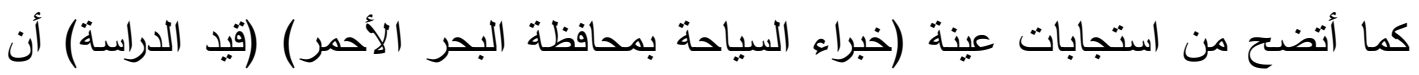

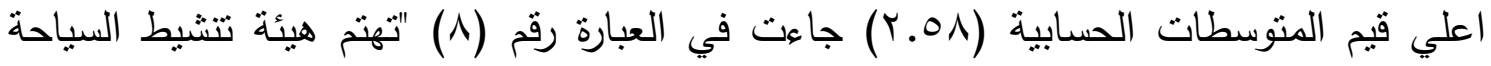

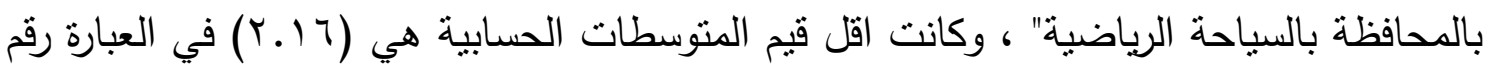

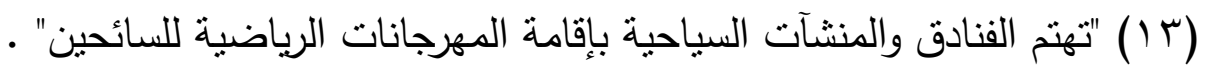
كذلك أنضح من استجابات عينة مسئولي الانشطة الرياضية داخل القري السياحية (قيد

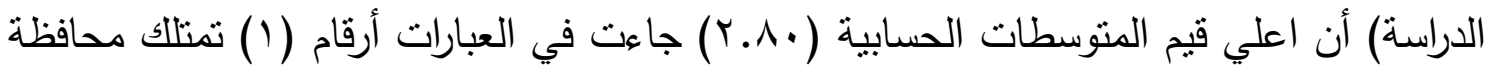

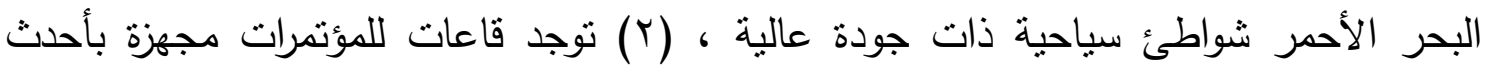

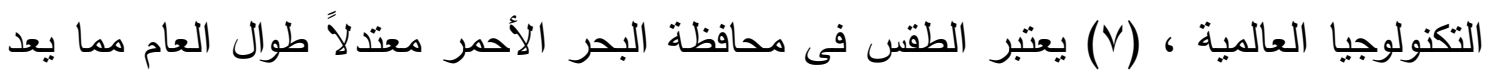




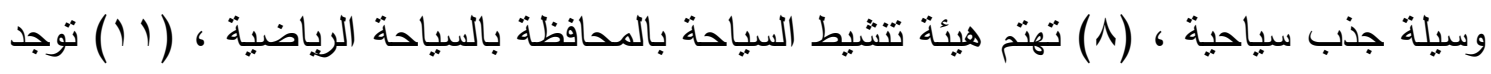

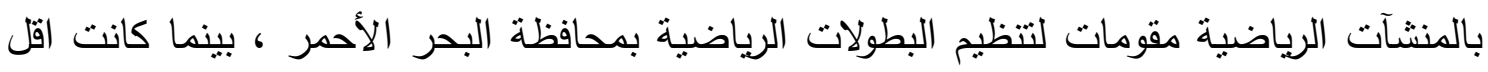

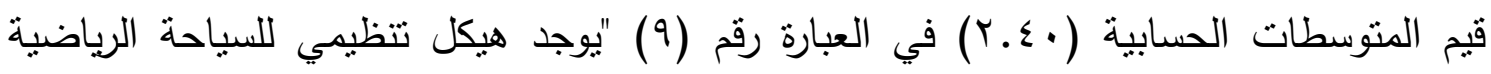

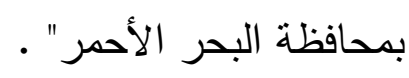
ايضاً أتضح من استجابات عينة المترددين على القرى السياحية (قيد الدراسة) أن اعلي قيم

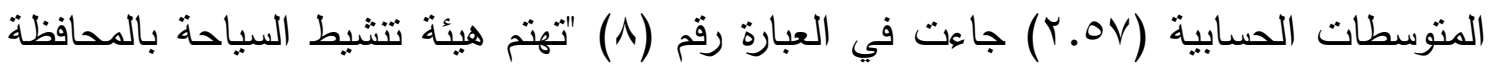

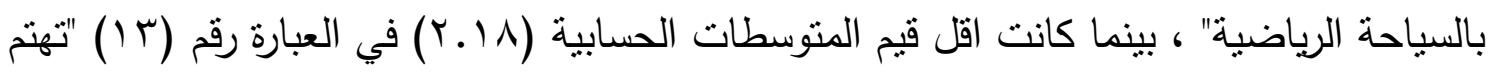

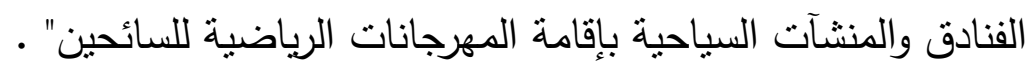

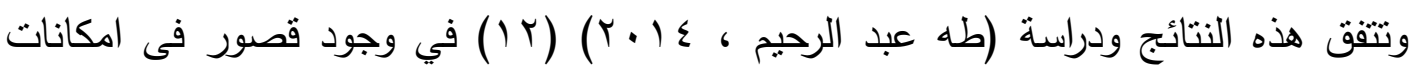
القرى السياحية الحكومية وعدم الوعى الكافي للمستفدين والمديرين بأهمية الرياضة والثية والسياحة

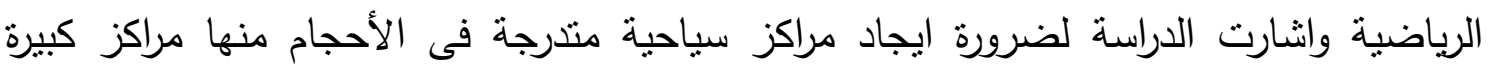
وأخرى صغيرة على محاور تربط بين المراكز الكبيرة والواقعة بالقرب من المراكز العمرانية القائمة ، ويعتبر هذا البديل مثالى حيث أنة يجمع اكبر قدر من الإيجابيات بالاستمتاع بالثاطئ وإمكاناتة البيئية.

كما تتفق النتائج مع دراسة (صلاح الدين عبد الوهاب ، .99 19)(1 (1) في اهمية تخطيط الحملات والبرامج النتشيطية فى الخارج والداخل فى إطار تسويقى متكامل تتعاون فية الأجهزة

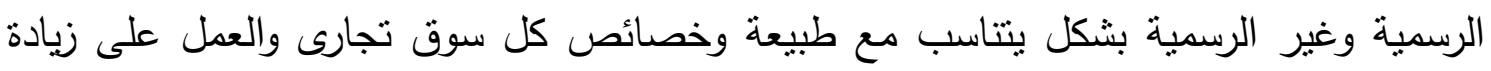

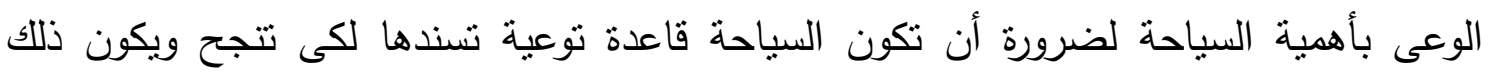

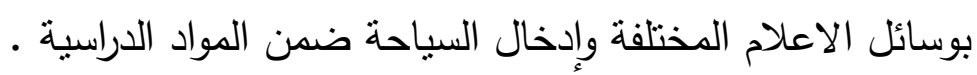

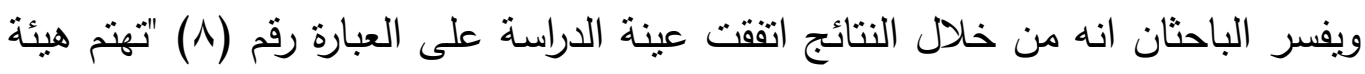

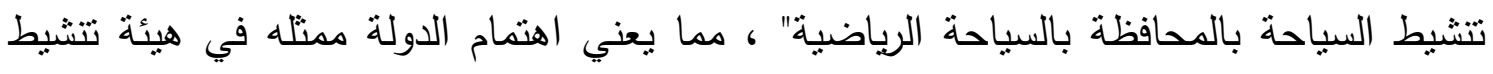

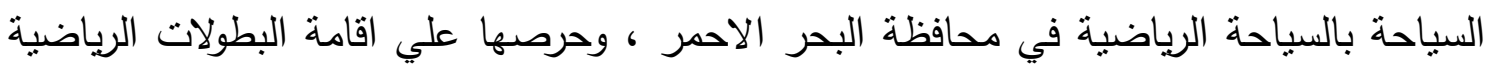

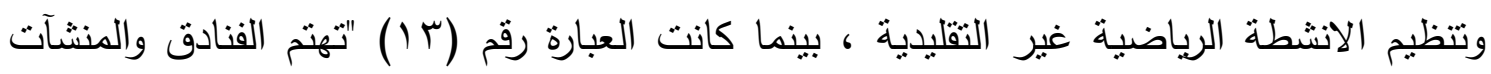

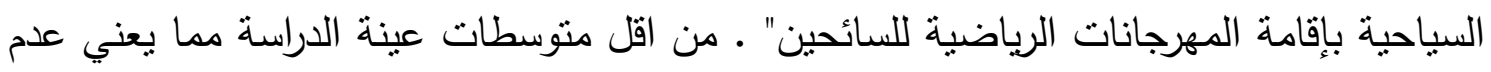

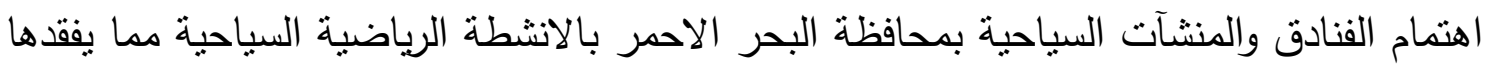

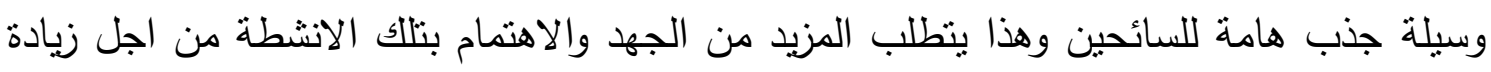
اعداد السائحين في هذا المجال الهام . 


\section{r- بالنسبة لمحور انماط السياحة الرياضية فى البحر الأحمر :}

جدول (·) (1)

النسب المئوية والتكرارات لاستجابات عينة الدراسة في عبارات

المحور الثاني : انماط السباحة الرياضية فى البحر الأحمر ( ن = . . 1 )

\begin{tabular}{|c|c|c|c|c|c|c|c|c|c|c|}
\hline \multirow{2}{*}{ 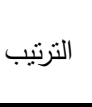 } & \multirow{2}{*}{ المئوية - النسبة } & \multirow{2}{*}{ 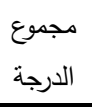 } & \multicolumn{2}{|c|}{ ע } & \multicolumn{2}{|c|}{ 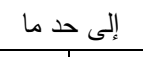 } & \multicolumn{2}{|c|}{ نعم } & \multirow{2}{*}{ العبـــــــــارة } & \multirow{2}{*}{ ? } \\
\hline & & & $\%$ & ك & $\%$ & ك & $\%$ & ك & & \\
\hline $1 \varepsilon$ & $7 \ldots$ & $1 \wedge$. & 00 & .0 & 1. & 1. & ro & ro & ليتم تتظيم بطولات رياضية شاطئية محلية بمحافظة البحر الأحمر . & $1 \varepsilon$ \\
\hline 10 & $0 \leqslant \ldots$ & $17 r$ & 09 & .9 & 19 & 19 & r. & r. & ليتم تتظيم بطولات رياضية شاطئية دولية بمحافظة البحر الأحمر . & 10 \\
\hline 17 & SV.r & $1 \leq r$ & $T \varepsilon$ & $7 \varepsilon$ & r. & r. & 1 & 7 & |لهيتم المحافظة بتتظيم بطولات فى الألعاب الجامعية أثناء ركود الموسم & 17 \\
\hline 11 & $\wedge . .$. & $r \varepsilon$. & ro & ro & $1 \cdot$ & $1 \cdot$ & 70 & 70 & تعمل هيئة تنشيط السياحة بالمحافظة على جذب تتظيم بطولات عالمية & iv \\
\hline$\circ$ & 19.7V & r79 & . & . & r^ & rı & $v_{1}$ & vi & | ليتم التسويق للمنشآت السياحية الرياضية بالمحافظة من خلال & 11 \\
\hline 1. & מיז & $r \leqslant 1$ & $1 \varepsilon$ & $1 \varepsilon$ & r & r & 00 & 00 & |لتهتم الفنادق السياحية بوجود عناصر تسويقية متخصصة فى السياحة & 19 \\
\hline r & $90 \ldots$ & rso & . & . & 10 & 10 & 10 & 10 & |تمثل الرياضات الترويحية عنصراً اساسياً فى البرامج السياحية المقدمة & r. \\
\hline ir & $79 .$. & $r \cdot r$ & <0 & $\leq 0$ & $r$ & $r$ & or & or & |ليمنل الموقع الجغرافي بمحافظة البحر الأحمر أهم عناصر الجذب & r) \\
\hline$\varepsilon$ & Tצ.r & rAT & 7 & 7 & 0 & 0 & 19 & 19 & لمن الدتم إدارات المنشآت السياحية باستقطاب ابطال رياضية عالمية كنوع & rr \\
\hline$\wedge$ & Aะ.TV & ros & $r$. & $r$. & 7 & 1 & $V \varepsilon$ & $V \varepsilon$ & لتبالمحتبر الرياضات الثناطئية المختلفة أهم عناصر الجذب السياحى & rT \\
\hline 1 & $9 \wedge .7 \vee$ & raT & . & · & $\varepsilon$ & $\varepsilon$ & 97 & 97 & |ليتم تفعيل موقع إلكتروني على شبكة المعلومات الدولية للترويج للأنشطة & $r \varepsilon$ \\
\hline ^ مكرر & Aะ.TV & ros & 1. & 1. & r & rT & $T \varepsilon$ & $7 \varepsilon$ & 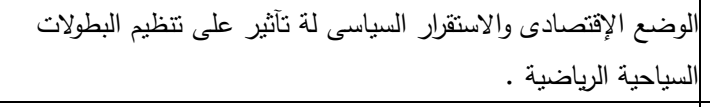 & ro \\
\hline 15 & $70 . .$. & 190 & ro & ro & 00 & 00 & $r$. & $r$. & ثقام بطولات صيد الأسماك بصورة منتظمة بمحافظة البحر الأحمر . & ru \\
\hline V & $10 . .$. & roo & 11 & 11 & r & r & 7 & 77 & ميداً. مكان السياحة الرياضية بمحافظة البحر الأحمر ضمن خطط الدولة & TV \\
\hline 7 & 19... & rTV & 1. & 1. & ir & $1 \pi$ & VV & VV & |تحرص شركات السياحة العالمية على توجيه السياح لمحافظة البحر & rA \\
\hline r & 90.77 & YAV & . & . & Ir & ir & AV & AV & |لحرص الاتحادات الرياضية الدولية على منح المحافظة حقوق نتظيم & $r q$ \\
\hline
\end{tabular}

يتضح من جدول (• () التكرارات والنسب المئوية لاستجابات عينة الدراسة من ( مديري

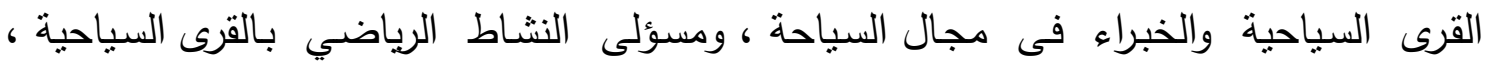

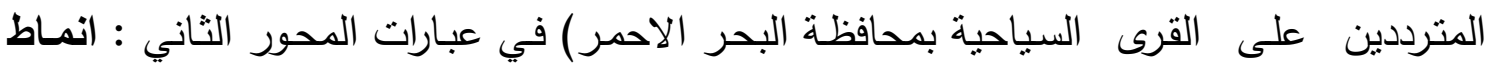

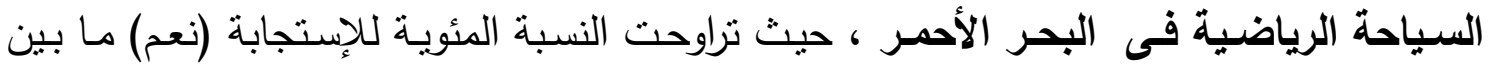




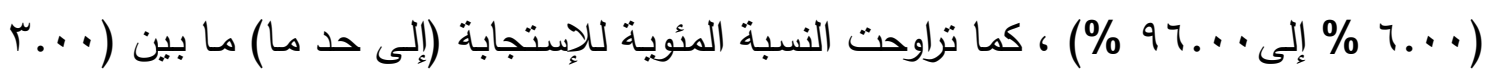

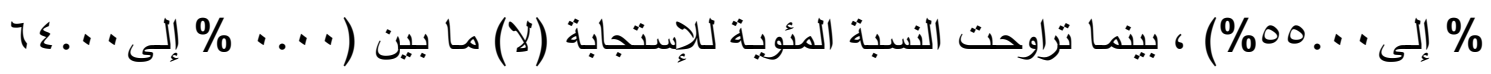
\%) ، وجاءت النسبة المئوية الكلية لمجموع الدرجات المقدرة لكل عبارة في استجابات العينة ما بين

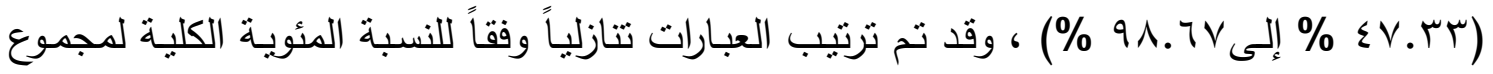
الدرجات المقدرة لكل عبارة في استجابات العينة موضحة انماط السياحة الرياضية فى محافظة البحر الأحمر: - (البات وتتفق هذه النتائج ودراسة (محمود اسماعيل ، 17 ـ ب) (7 (1 ) أن وزارة السياحة المصرية

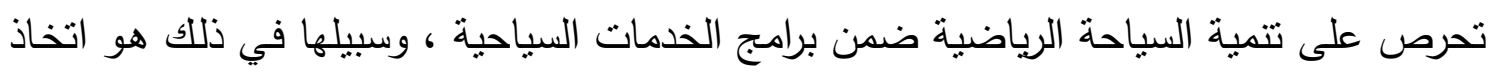

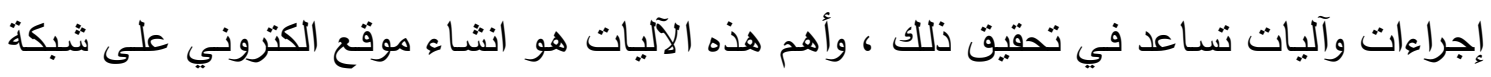

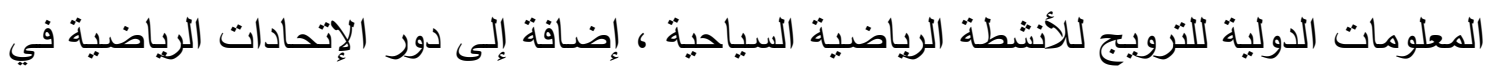

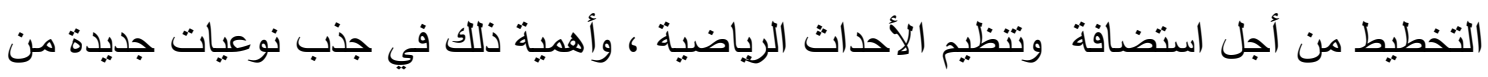

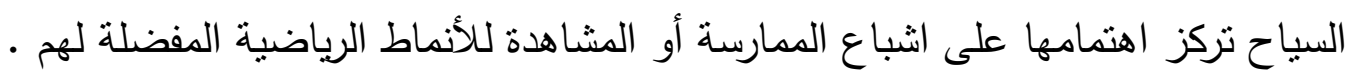

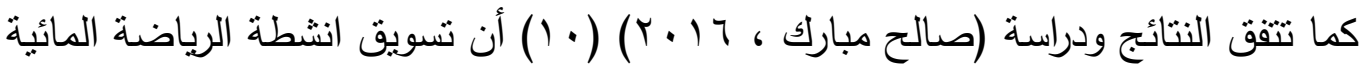

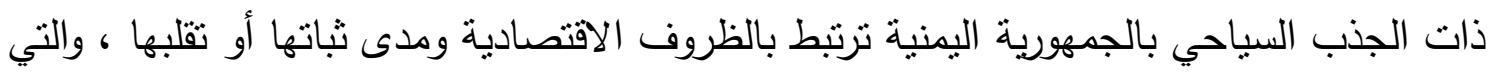

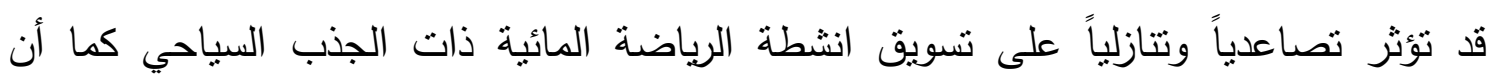

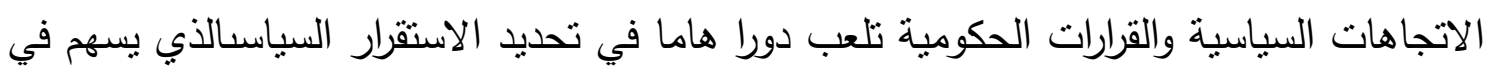

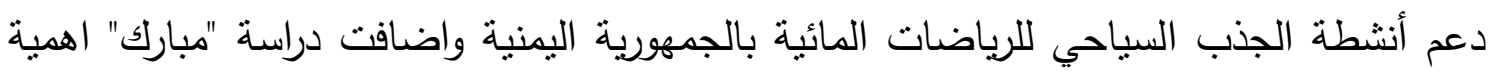

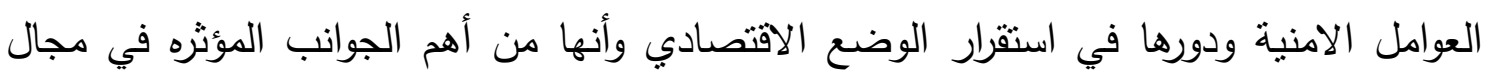

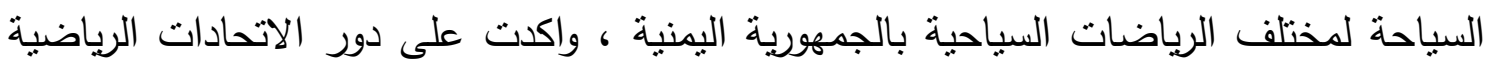

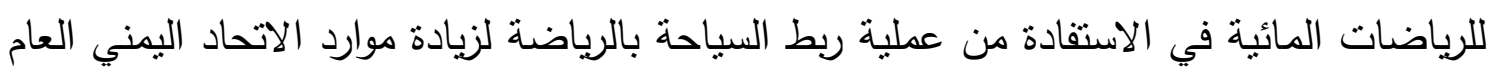
للسباحة والألعاب المائية بشكل خاص ونشر هذه الرياضات في الجمهورية اليمنية للمساهمة في

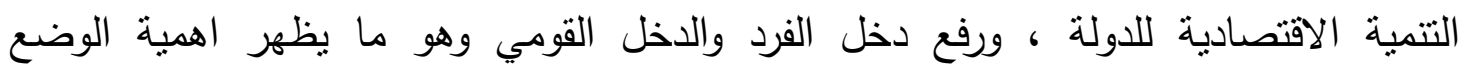
الإقتصادى والاستقرار السياسى وتآثيرهم على استضافة وتتظيم البطولات السياحية الرياضية

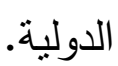

أيضاً تتفق هذه النتائج ودراسة (أحمد جمال ، 17 • (1) (1) أن تتظيم البطولات الرياضية

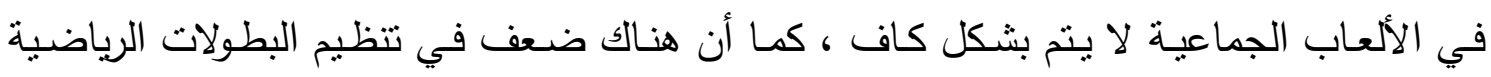

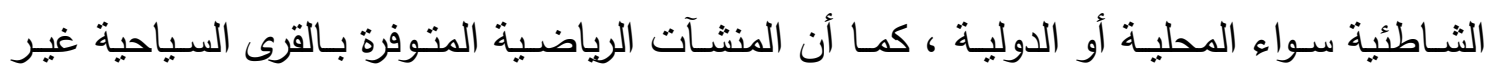

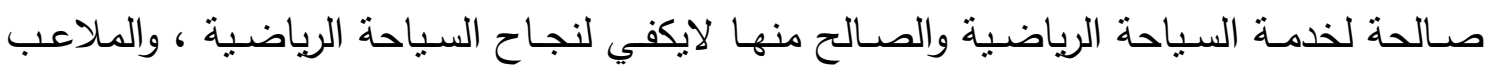


المتوفرة لا تتميز بالتتوع بحيث تتاسب مختلف الأنشطة الرياضية ، وأن الإمكانات المادية المتاحة

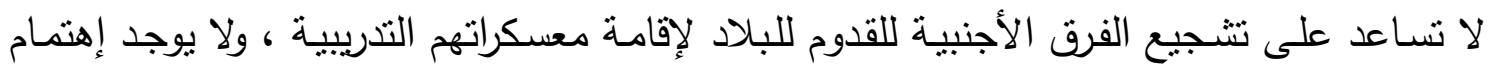

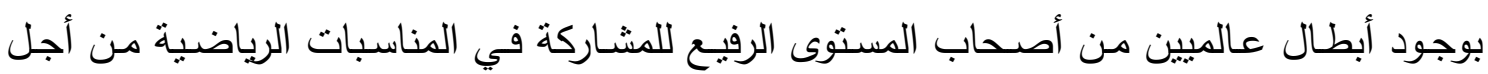

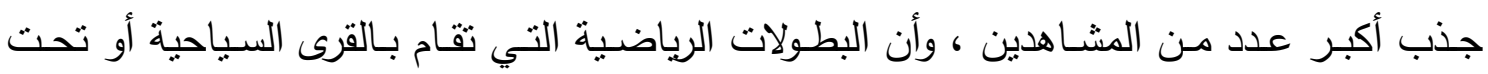
رعايتها محدودة ومقتصرة على رياضـات دون غيرها ، إلى جانب عدم الإستفادة من الإمكانات الطبيعية في إقامة البطولات والمهرجانات المختلفة .

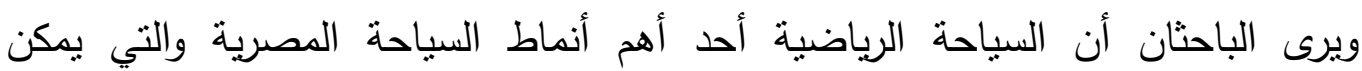

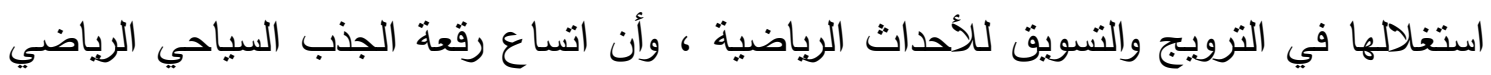

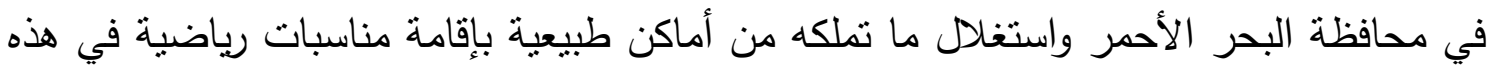

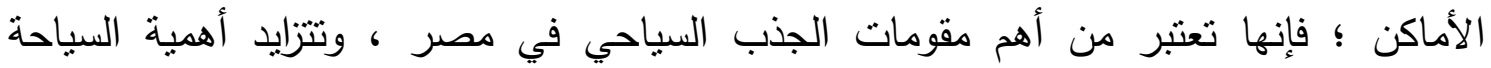

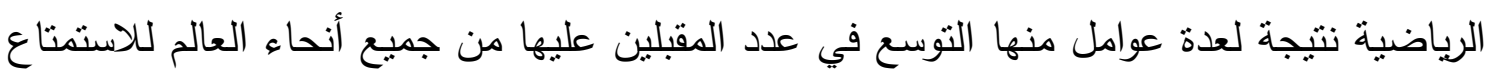

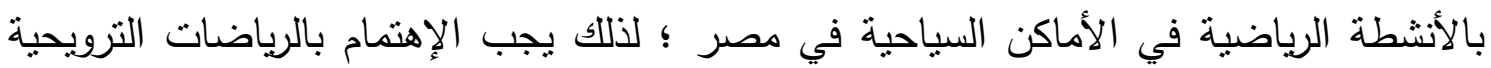

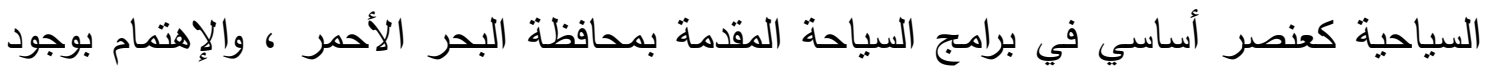
عناصر تنويقية كالأبطال الرياضيين ، والمختصين بالإضافة إلى حث الثركات السياحية العالمية

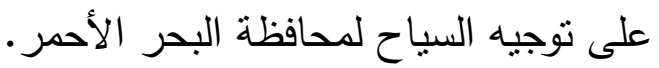




\section{جدول (I)}

\section{المتوسط الحسابي والإنحراف المعياري ومعامل الإلتواء لعبارات}

\section{المحور الثاني : انماط السياحة الرباضية فى البحر الأحمر ( ن = . . 1 )}

\begin{tabular}{|c|c|c|c|c|c|c|c|c|c|c|c|c|}
\hline \multicolumn{3}{|c|}{ 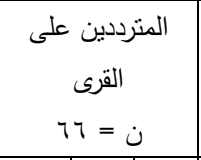 } & \multicolumn{3}{|c|}{ مسؤلى النشاط } & \multicolumn{3}{|c|}{ 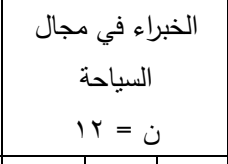 } & \multicolumn{3}{|c|}{$\begin{array}{l}\text { مديري القرى } \\
\text { السياحية } \\
\end{array}$} & \multirow[t]{2}{*}{ العبــــــــارة } \\
\hline$J$ & $\varepsilon$ & a & J & $\varepsilon$ & 5 & J & $\varepsilon$ & 5 & J & $\varepsilon$ & 5 & \\
\hline $\begin{array}{c}- \\
1 . r V\end{array}$ & 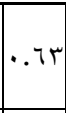 & Y.7. & $1.77-$ & $\| v$. & Y.7. & $.999-$ & $\because v q$ & Y. $\varepsilon)$ & $\begin{array}{c}- \\
1 . \leqslant 0\end{array}$ & $.7 \mathrm{~V}$ & r.ON & | اليتم تنظيم بطولات رياضية شاطئية محلية بمحافظة البحر \\
\hline $\begin{array}{c}- \\
1 .+r\end{array}$ & .01 & $\mathrm{r} .0 \mathrm{~V}$ & $1.11-$ &.$- v 1$ & Y.o. &..$\leqslant \wedge-$ & $\because v 0$ & r. ro & $\begin{array}{c}- \\
. . \Lambda 1 \\
\end{array}$ & $\because \leqslant 9$ & T.7T & |بيتم تنظيم بطولات رياضية شاطئية دولية بمحافظة البحر \\
\hline $\begin{array}{c}- \\
1.199\end{array}$ & .71 & 4.71 & $1.77-$ & 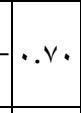 & Y.7. & $\because V Y-$ & $\because \vee \wedge$ & T.rT & \begin{tabular}{c|}
- \\
$\cdot . \Lambda 1$ \\
\end{tabular} & $\because \leqslant 9$ & T.7T & 17|تهنم المحافظة بتنظيم بطولات فى الألعاب الجامعية أثناء \\
\hline $\begin{array}{c}- \\
1.0 Y\end{array}$ & .09 & r.70 & $1.77-$ & 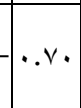 & Y.7. & .rY- &.$V Y$ & r.17 & $\begin{array}{c}- \\
1 . . v\end{array}$ & $.7 v$ & r.o. & |l|نطعل هيئة تتشيط السياحة بالمحافظة على جذب تتظيم \\
\hline $\begin{array}{r}- \\
1.9 .\end{array}$ &.$V Y$ & $r . \leqslant r$ & Y.YA- &. $.7 V$ & Y.V. & $. V Y-$ & $\because v q$ & T.rT & \begin{tabular}{c|}
- \\
$\cdot V r$ \\
\end{tabular} & $.7 V$ & r. $\varepsilon 1$ & |ريتخ التصصين للمنشآت السياحية الرياضية بالمحافظة من خلال \\
\hline $\begin{array}{c}- \\
-9 \vee\end{array}$ & $\because \vee \vee q$ & $r . \leqslant r$ & $1 . \vee \wedge-$ &.$- \leqslant Y$ & Y.A. & $1 . \leqslant 0-$ & $.7 \mathrm{~V}$ & r.01 & \begin{tabular}{c|c}
- \\
.$- r q$ \\
\end{tabular} & .01 & r.ON & | 1 |تهتم الفنادق السياحية بوجود عناصر تسويقية متخصصة فى |لرياضية \\
\hline $\begin{array}{c}- \\
1 .+r\end{array}$ & .01 & r.ov & (1.VA- &..$\leqslant Y$ & Y.A. & $\| V T-$ & 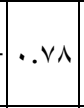 & T.rT & $\begin{array}{c}- \\
. \wedge 1 \\
\end{array}$ & $\because \leqslant 9$ & r.TT & • باتمثل الرياضات الترويحية عنصراً اساسياً فى البرامج السياحية \\
\hline $\begin{array}{c}- \\
1 . \Sigma 1\end{array}$ &. .71 & 4.09 & $1 . .+5-$ & 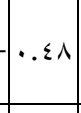 & Y.V. &..$\leqslant \leqslant-$ & .70 & T.rT &. .49 &. .01 & Y. $\leqslant 1$ & |r|ليمثل الموقع الجغرافي بمحافظة البحر الأحمر أهم عناصر \\
\hline $\begin{array}{c}- \\
\cdots 9 . \\
\end{array}$ & $\because V Y$ & $r . \leqslant r$ & $1.11-$ & $\because v 1$ & T.o. & $1 . . v-$ &.$T V$ & Y.०. & $\begin{array}{c}- \\
\cdot V r \\
\end{array}$ & $.7 V$ & $r \leqslant$ & 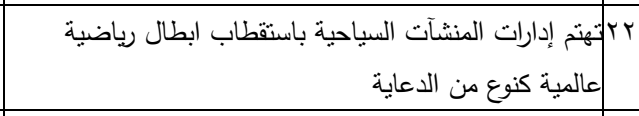 \\
\hline $\begin{array}{c}- \\
. \wedge \Lambda \\
\end{array}$ & $\because v \varepsilon$ & $r . \leqslant Y$ & $1.77-$ & $\cdots v \cdot$ & Y.7. & $.1 \mathrm{~V}-$ &. .74 & T.ro & \begin{tabular}{c|}
- \\
. .49 \\
\end{tabular} & .01 & r.ON & 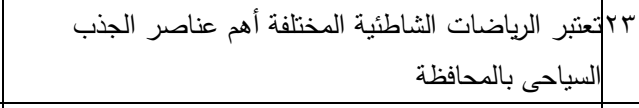 \\
\hline $\begin{array}{l}- \\
. \wedge r \\
\end{array}$ & $\because v \leqslant$ & Y.s. & $1.77-$ & $\because v \cdot$ & Y.7. & .rY- &.$V Y$ & T.17 & $\begin{array}{c}- \\
. .49 \\
\end{array}$ & .01 & r.ON & 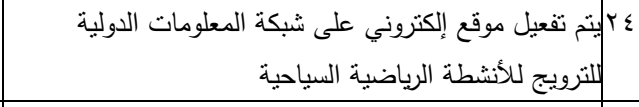 \\
\hline $\begin{array}{c}- \\
1.0 Y\end{array}$ &. .09 & r.70 & $1 . .+r-$ & 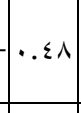 & Y.V. & $\because V Y-$ & $\because \vee \wedge$ & T.TT & $\begin{array}{c}- \\
\cdot . V r\end{array}$ & $.7 V$ & Y. $\leqslant 1$ & or |الوضع الإقتصادى والاستقرار السياسى لة تآثير على نتظيم \\
\hline $\begin{array}{c}- \\
1.7 . \\
\end{array}$ &. $.7 T$ & r.70 & Y.Y人- &..$T \mathrm{~V}$ & Y.V. & .rY- &.$V Y$ & T.17 & \begin{tabular}{c|}
- \\
$\cdots V r$ \\
$V$
\end{tabular} & $.7 \mathrm{TV}$ & Y. $\leqslant 1$ & بَ |تقام بطولات صيد الأسماك بصورة منتظمة بمحافظة البحر \\
\hline $\begin{array}{c}- \\
\cdots 94 \\
\end{array}$ & $\because \vee \wedge$ & $r . \leqslant Y$ & $1.77-$ & $\because v \cdot$ & Y.T. &..$\leqslant \wedge-$ & $\because v_{0}$ & T.YO & \begin{tabular}{c|}
- \\
$1 . . v$
\end{tabular} & $.7 V$ & r.o. & |r|r مكان البياحة الرياضية بمحافظة البحر الأحمر ضمن خطط \\
\hline $\begin{array}{c}- \\
1 . V r\end{array}$ & .79 & r.70 & $1.11-$ & $a v 1$ & T.O. & $\because V Y-$ & $\because \vee \wedge$ & T.RT & $\begin{array}{c}- \\
1 . . v\end{array}$ & $.7 V$ & r.o. & |ب البحر الأحمر شركات السياحة العالمية على توجيه السياح لمحافظة \\
\hline $\begin{array}{c}- \\
.11 \\
\end{array}$ &..$\Delta r$ & r.. T & $\cdot . \Sigma \wedge-$ &. $.0 Y$ & Y.T. & $1 . \leq 0-$ &. $.7 V$ & T.01 & $\begin{array}{c}- \\
1 . . v\end{array}$ & $.7 V$ & r.o. & هو |تحرص الاتحادات الرياضية الدولية على منح المحافظة \\
\hline
\end{tabular}


يتضح من جدول (1) استجابات فئات العينة علي عبارات المحور الثاني : انماط السياحة الرياضية فى البحر الأحمر - حيث جاءت استجابات (مديري القرى السياحية بمحافظة البحر

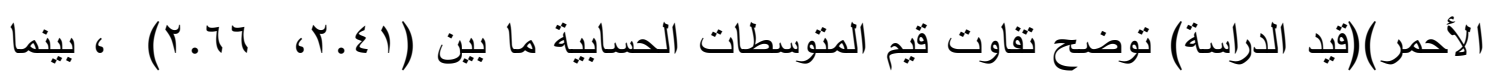

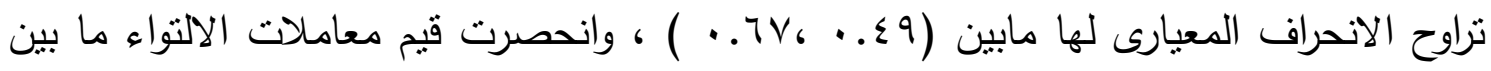


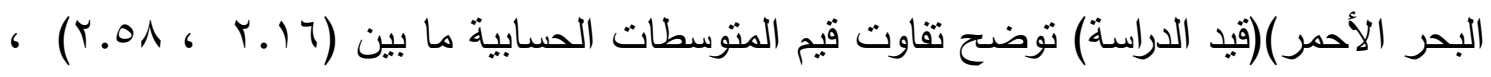

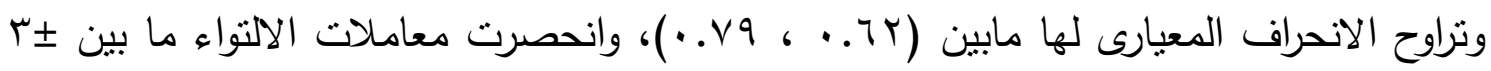

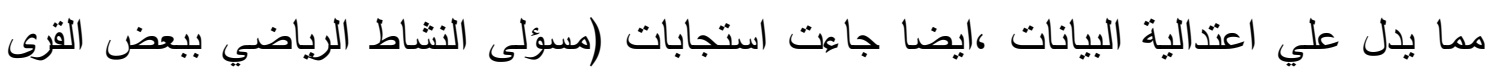

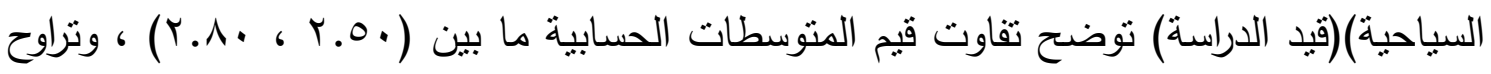

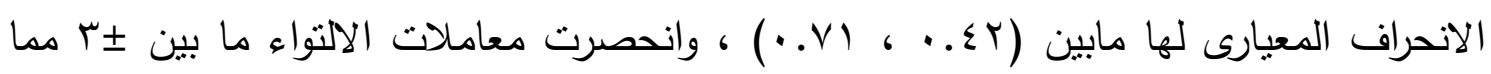

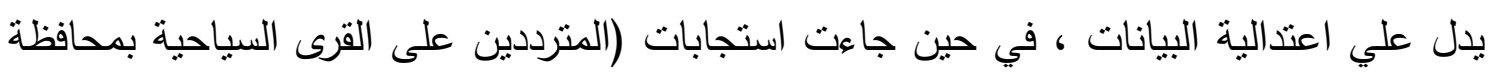

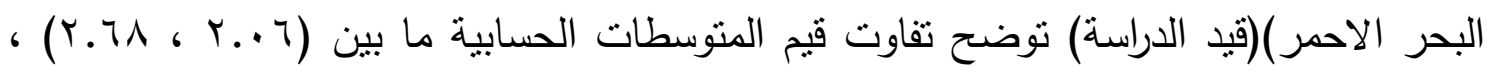

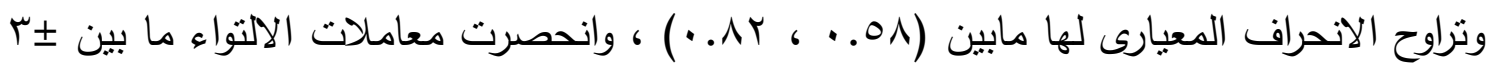
مما بدل علي اعتدالية البيانات. كما تثيبر نتائج الجدول حول محور (انماط السياحة فى محافظة البحر الأحمر) وجود

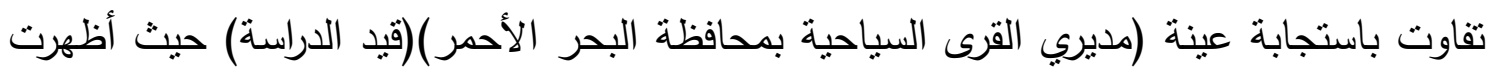

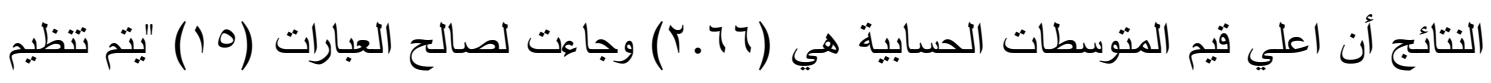

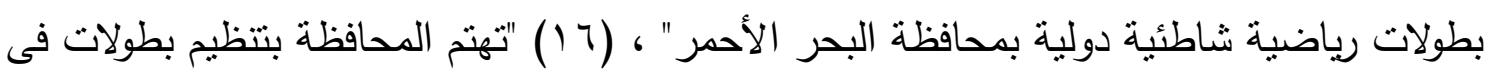

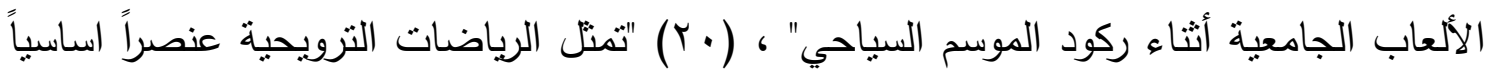

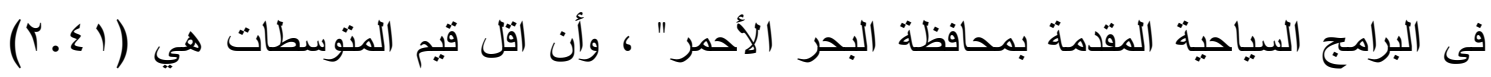

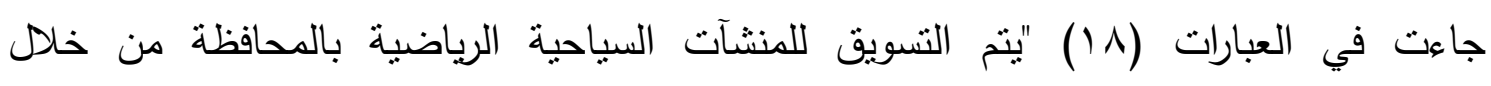

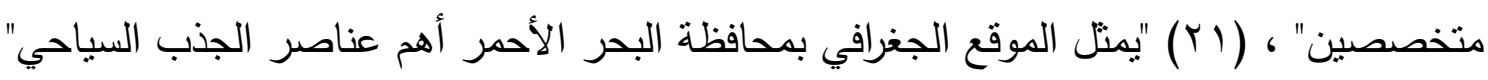

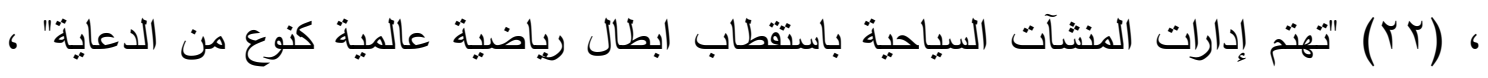

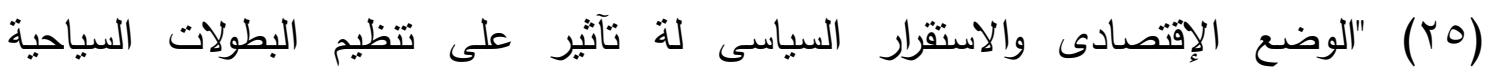

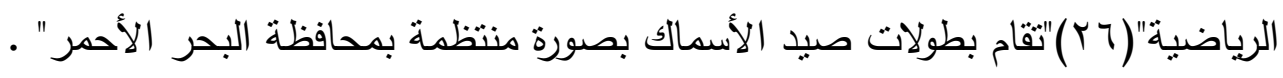

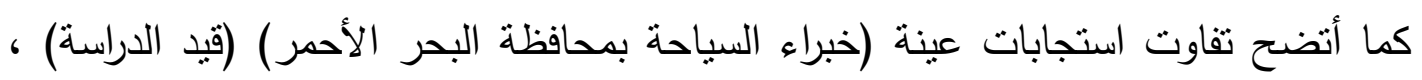

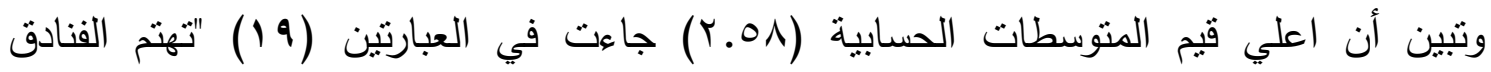
السياحية بوجود عناصر تسويقية متخصصة فى السياحة الرياضية" ، (Y9) "تحرص الاتحادات 
الرياضية الدولية على منح المحافظة حقوق تتظيم البطولات" ، بينما كانت اقل قيم المتوسطات

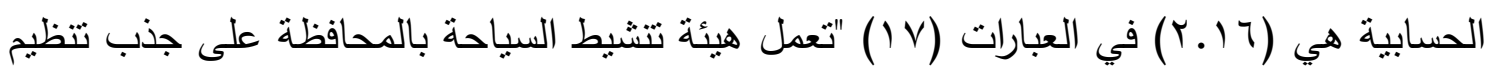

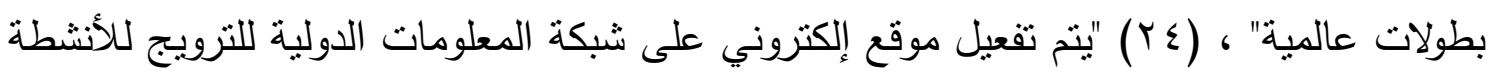
الرياضية السياحية" ، (TY) تقام بطولات صيد الأسماك بصورة منتظمة بمحافظة البحر الأحمر . كذللك أتضح تفاوت في استجابات عينة (مسئولي الانثطة الرياضية داخل القري السياحية)

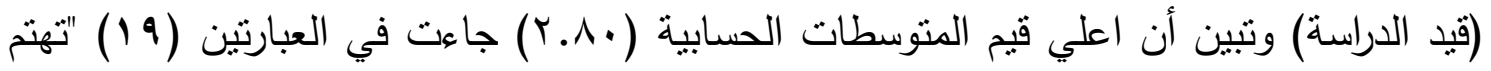

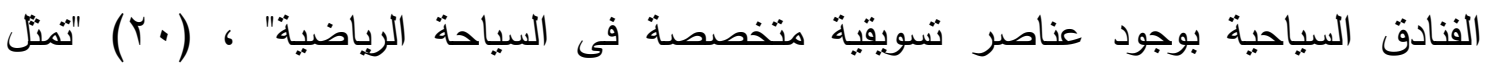

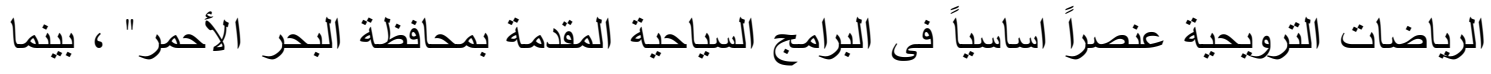

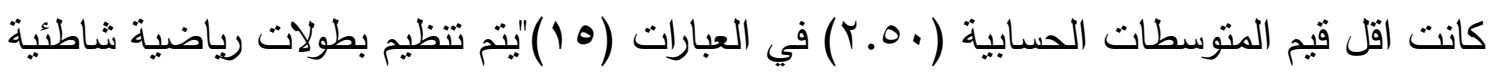

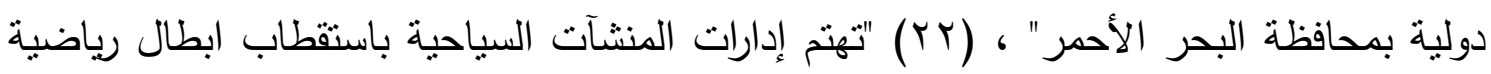

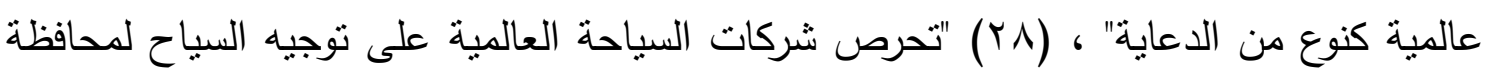

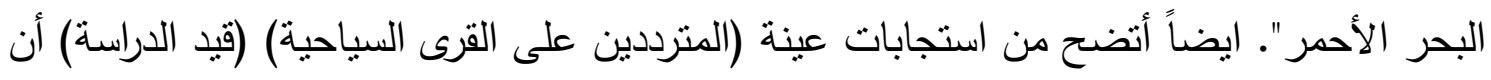

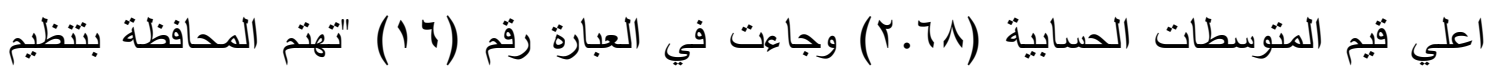
بطولات فى الألعاب الجامعية أثناء ركود الموسم السياحي" ، بينما كانت اقل قيم المتوسطات

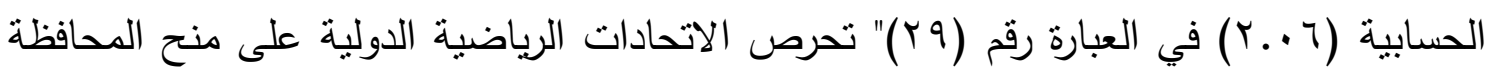

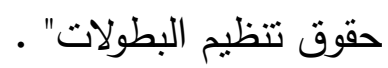

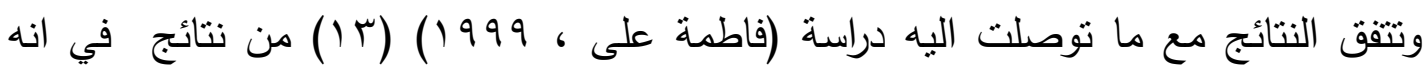

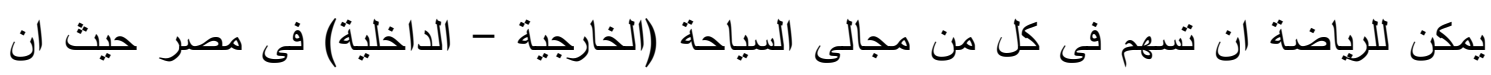
السياحة لم تعد تقتصر فى الوقت الحاضر على لمن زيارة الآثار المصرية القديمة ولكن ربط السياحة

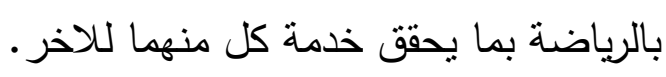

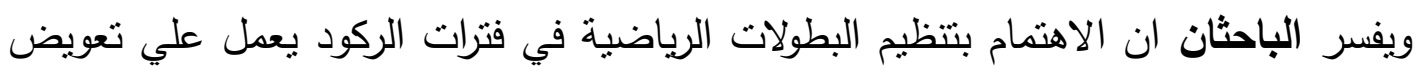

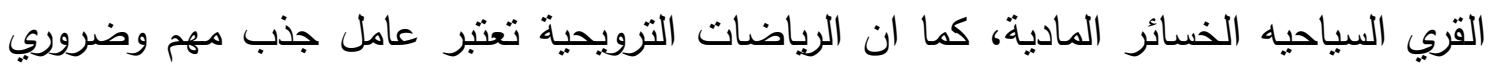

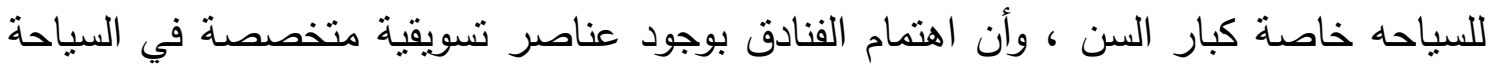

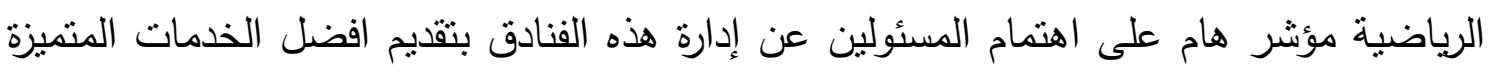

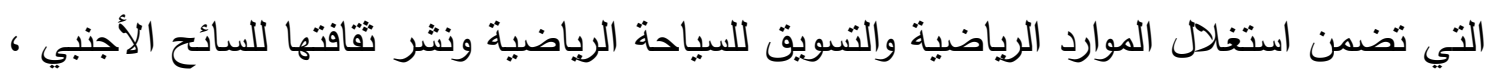

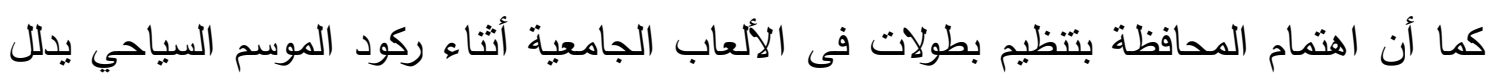

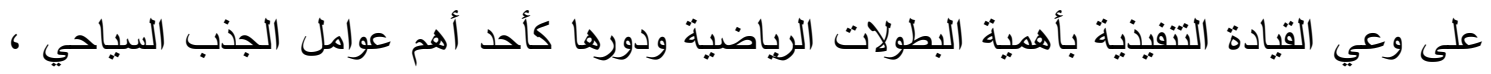
اما عدم المداومة على تتظيم مسابقات لرياضة الصيد البحري فقد يؤدي لانخفاض انتشارها وعدم لئه 
استغلال مورد هام من موارد السياحة الرياضية ، فصبد الاسماك احد اهم الرياضات السياحية وأحد اهم وسائل الجذب السياحي بمحافظة البحر الاحمر • ويري الباحثان ضرورة أن تركز خطة التتمية السياحية لمنطقة البحر الأحمر على تحقيق التتمية المستدامة للحفاظ على المقومات الطبيعية التى تشكل عناصر الجذب السياحى بها ، والتى تتنوع بين شواطئ وجبال ومناخ ومحميات وشعاب مرجانية بالاضافة لتظيم واقامة البطولات والمهرجانات السياحية الرياضية .

ب- بالنسبة لمحور سبل تنشيط السياحة الرياضية بمحافظة البحر الأحمر : جدول (IT)

النسب المئوية والتكرارات لاستجابات عينة الدراسة في عبارات

المحور الثالث : سبل نتشيط السياحة الرياضية بمحافظة البحر الأحمر ( ن = . . 1 )

\begin{tabular}{|c|c|c|c|c|c|c|c|c|c|c|}
\hline \multirow{2}{*}{ الترتيب } & \multirow{2}{*}{ 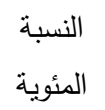 } & \multirow{2}{*}{ 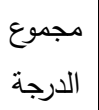 } & \multicolumn{2}{|c|}{$y$} & \multicolumn{2}{|c|}{ إلى حد ما } & \multicolumn{2}{|c|}{ نعم } & \multirow{2}{*}{ العبــــــــــارة } & \multirow{2}{*}{ r } \\
\hline & & & $\%$ & ك5 & $\%$ & ك & $\%$ & 5) & & \\
\hline r & QY.TV & rVA & $r$ & r & 17 & 17 & $\wedge$ & 1) & |فحرص المنشآت السياحية على تقيم أفضل المستويات العالمية & $r$. \\
\hline 11 & TY.TV & 111 & rq & rq & $r \varepsilon$ & $\Gamma \varepsilon$ & rV & TV & 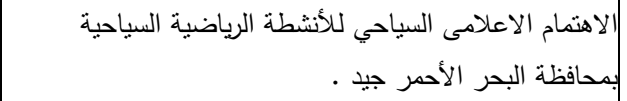 & ri \\
\hline r مكرر & QY.TV & rVA & 7 & 7 & 1. & 1. & $\wedge \varepsilon$ & $\Lambda \varepsilon$ & 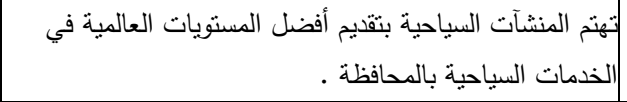 & Tr \\
\hline 1 & $9 \wedge .$. & rq & . & . & 7 & 7 & $9 \varepsilon$ & $9 \leq$ & |قفوم هيئة تتشيط السياحة بالمحافظة باستطلاع رأى السائحين & r \\
\hline 0 & 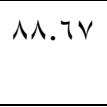 & ryt & V & V & $r$. & $r$. & VT & Vr & 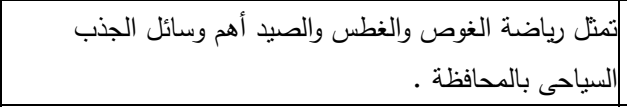 & $r \varepsilon$ \\
\hline$\varepsilon$ & r.T. & TVV & 9 & 9 & 0 & 0 & $\wedge \uparrow$ & $\wedge T$ & |لثوم الفنادق رحلات السفاري الغير تقليدية للسائحين بمحافظة & ro \\
\hline$\wedge$ & NT.TV & rol & $1 \varepsilon$ & $1 \varepsilon$ & rI & YI & 70 & 70 & |من المثل البنية التحتية السياحية بمحافظة البحر الأحمر نسبة عالية| & די \\
\hline 1. & vi... & rIT & $\varepsilon r$ & $\varepsilon r$ & $r$ & $r$ & 00 & 00 & |لخدمة بالمحافظة السياحية فى زيادة مستمرة وتطور دائم تقديم أفضل & rv \\
\hline ه مكرر & $\Lambda \Lambda . T \vee$ & Y74 & 1. & 1. & $1 \varepsilon$ & $1 \varepsilon$ & $V Y$ & VY & |نوجد غرفة عمليات لحل المشكلات الطارئة وتزيل العقبات أمام & זᄉ \\
\hline IT & $01 \ldots$ & 10r & 71 & $7 \wedge$ & 11 & 11 & TI & ri & لتساوى الددن السياحية بالبحر الأحمر في أعداد السائحين سنوياً . & rq \\
\hline 9 & אז.ו & $r \leq \varepsilon$ & IV & IV & rY & rT & 71 & 71 & | & $\varepsilon$. \\
\hline $1 \leq$ & $0 . .$. & 10. & 00 & 00 & $\varepsilon$. & $\varepsilon$. & 0 & 0 & |مغادرة المحافظة هيئة تنشيط السياحة بالتواصل المستمر مع السائحين بعد & $\varepsilon 1$ \\
\hline V & NV.r & rTT & Tr & Tr & ir & ir & vo & vo & |ريناء غالبة اليخوت أحد أهم عناصر الجذب السياحي نظراً لوجود & $\varepsilon r$ \\
\hline Ir & ov... & $|v|$ & $0 \leqslant$ & $0 \leqslant$ & rI & YI & ro & ro & |تمثل السياحة الرياضية نسبة قليلة جداً من السياحة بمحافظة & $\varepsilon r$ \\
\hline
\end{tabular}


يتضـح من جدول (r ( ) التكرارات والنسب المئوية لاستجابات عينة الدراسة من ( مديري

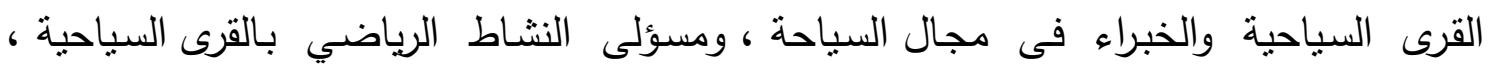

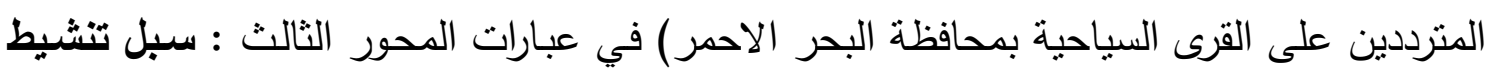

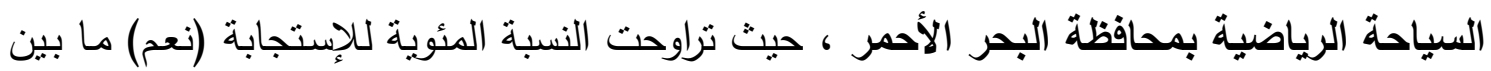

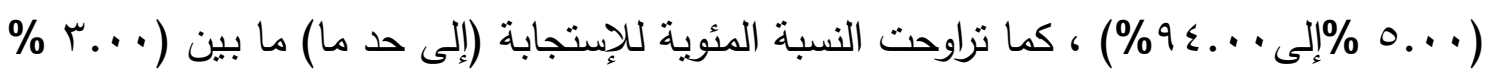

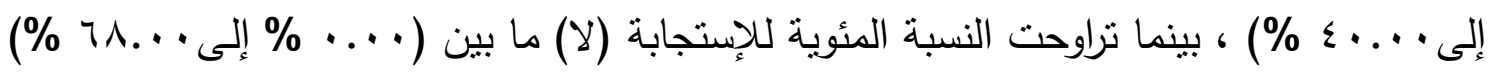

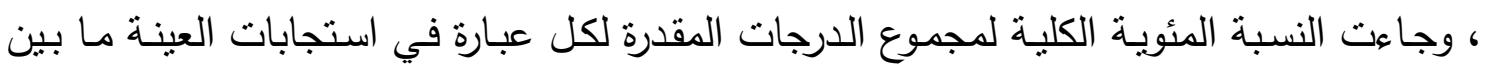

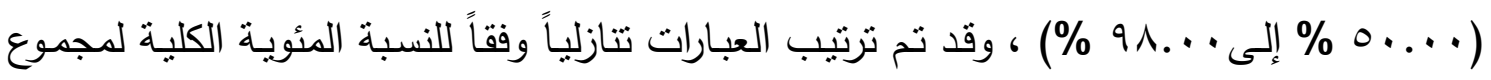

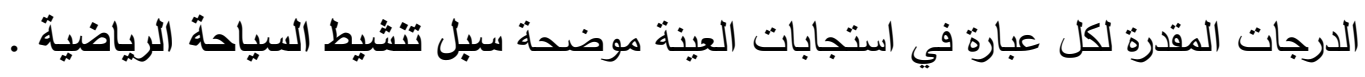

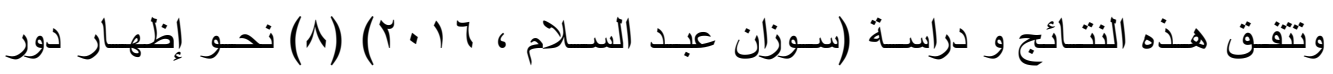

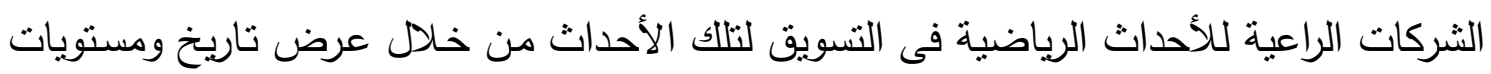

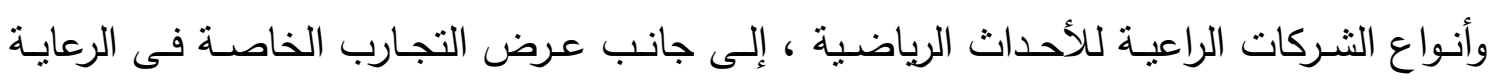

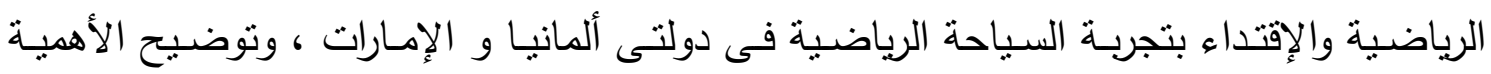

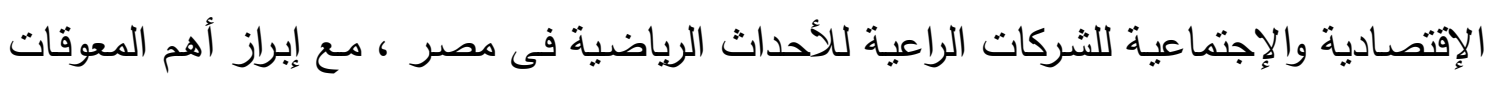

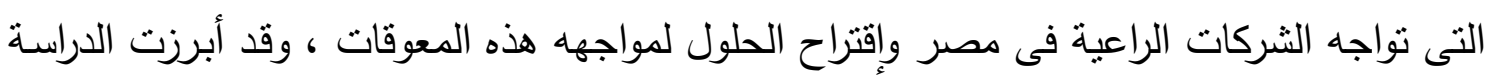

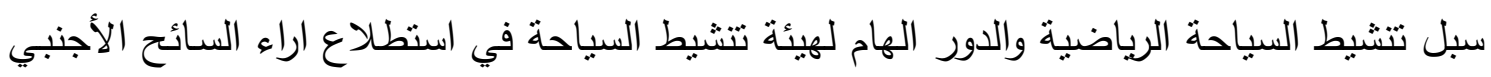

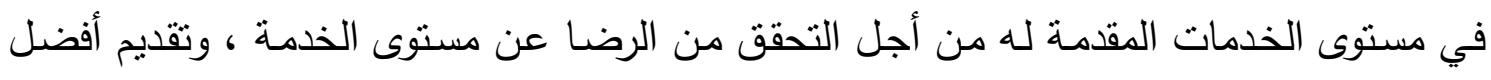

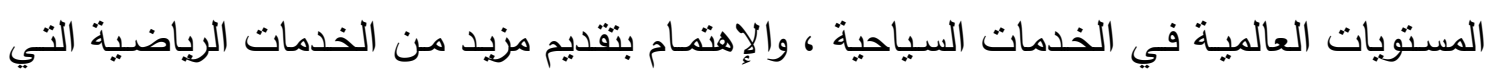

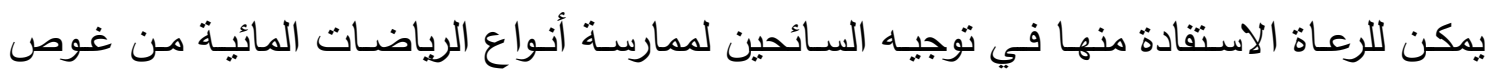
وغطس وصيد كأهم وسائل وسبل الجذب السياحى التي يمكن استغلالها.

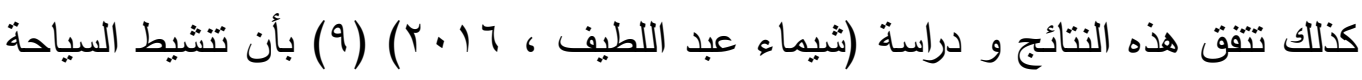

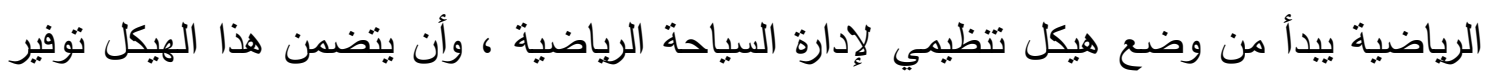

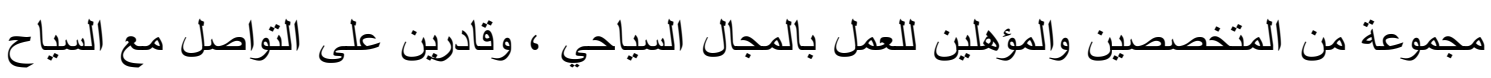

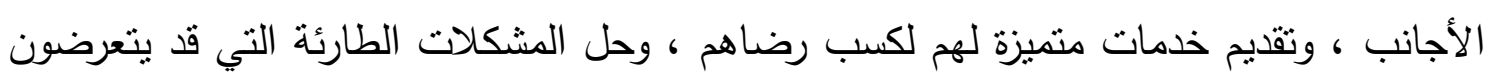

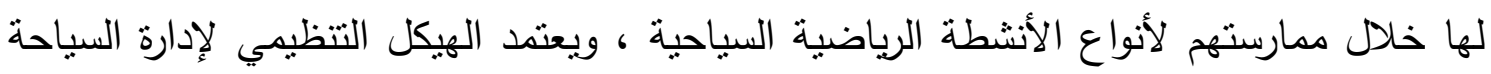

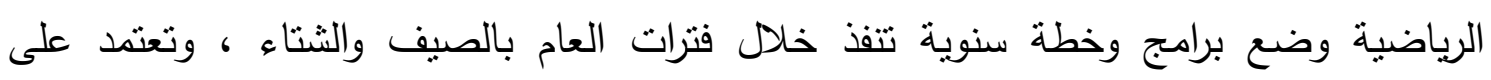

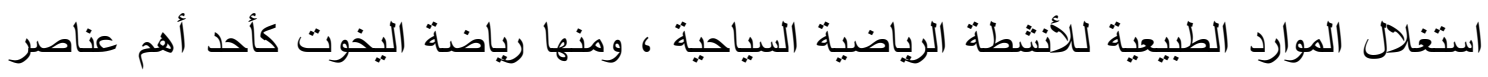

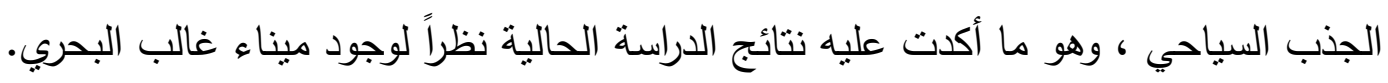




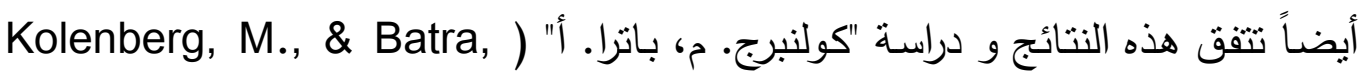

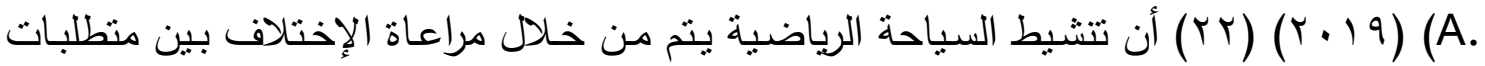
السياح الرياضيين ، ومنطلبات السياح غير الرياضيين ، حيث تختلف التوقعات تجاه السياحة الرياضية بالنسبة للسياح الرياضيين ، وغير الرياضيين ، وقد ركزت الدراسـة على دور الأجهزة

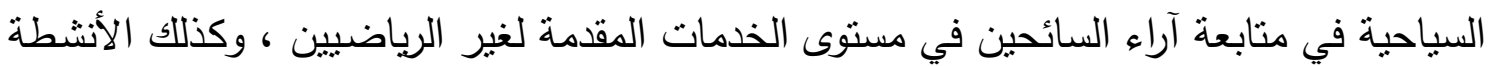

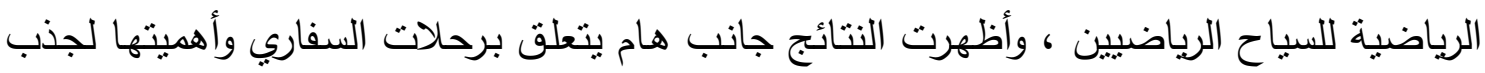

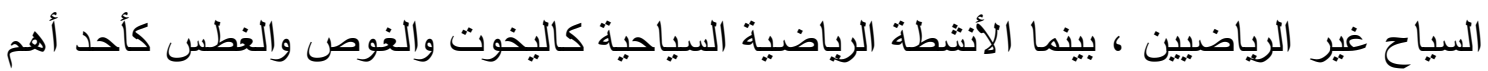

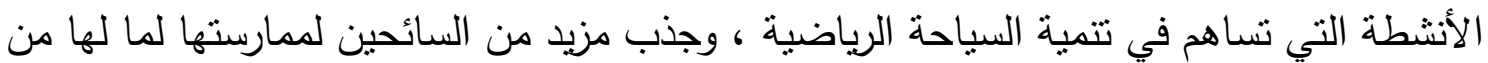

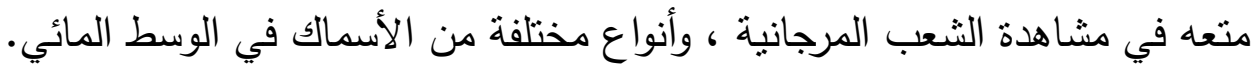

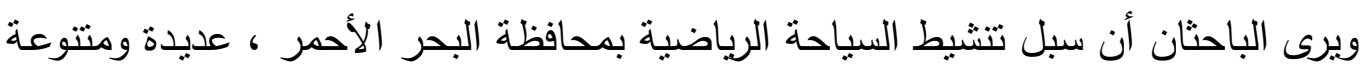

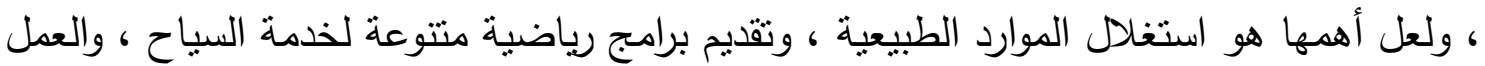

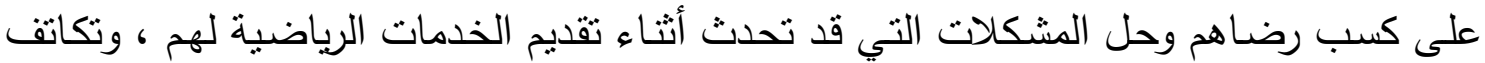
أجهزة الدولة ودعمها لخدمة البرامج والأنشطة الرياضية السياحية ، فكلها عوامل تساهم في تتشيط السياحة الرياضية بمحافظة البحر الأحمر . جدول (1)

المتوسط الحسابي والإنحراف المعياري ومعامل الإلتواء لعبارات المحور الثالث : سبل تتشيط السياحة الرياضية بمحافظة البحر الأحمر ( ن = . . 1 )

\begin{tabular}{|c|c|c|c|c|c|c|c|c|c|c|c|c|}
\hline \multicolumn{3}{|c|}{ 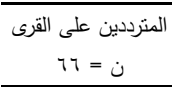 } & \multicolumn{3}{|c|}{ |مسؤلى النشاط الرياضي| } & \multicolumn{3}{|c|}{ 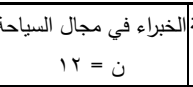 } & \multicolumn{3}{|c|}{ 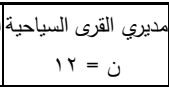 } & \\
\hline J & $\varepsilon$ & 5 & J & $\varepsilon$ & 5 & J & $\varepsilon$ & s & J & $\varepsilon$ & s & \\
\hline $1 . \vee 9-$ & .00 & r.v & $1.11-$ & $\cdot . \mathrm{v}$ & r.o. & $. .17-$ &. .19 & r... & $. . \Sigma \Lambda-$ &.$v_{0}$ & or.ro ro & كَ|تحرص الذنشآت السياحية على تقديم أفضل المستويات العالمية \\
\hline I.VY- & .01 & T.V & $1.74-$ &.$\cdot v$ & r.7. & $. .19-$ &. .9 . & r... & $. . \Sigma \Lambda-$ &.. $\mathrm{V}^{\circ}$ & or.ro & ب| الاهتمام الاعلامى السياحي للأنثطة الرياضية السياحية بمحافظة البحر الأحمر جبد . \\
\hline $1.91-$ & 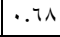 & r.7 & T.TA- &. .71 & T.Y. & $.+r_{-}-$ &.$V T$ & r.17 & $. \cdot \mathrm{rr}-$ & .T4 & 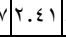 & لب|تهتم المنشآت السياحية بتقليم أفضل المستويات العالمية في الخدمات السياحية بالمحافظة \\
\hline $1 . \mathrm{Vr}-$ & .01 & r.v & $1.77-$ & $\cdot \cdot \mathrm{v}$ & T.T. & $.0 \mathrm{~V}-$ &.$\wedge \mathrm{V}$ & r.ro & $1 . . v-$ & $.7 \mathrm{~T}$ & 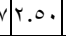 & كابـاتقوم هيئة تتشيط السباحة بالمحافظة باستطلاع رأى السائحين فى مستوى الخدمة . \\
\hline $1 . r .-$ &. $.1 \wedge$ & r.os & $1.11-$ &.$\cdot \mathrm{v}$ & r.o. & ..¿ی- & 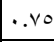 & r.ro & $1.50-$ & $.7 \mathrm{Tr}$ & $v+.01$ & 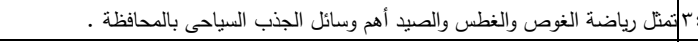 \\
\hline I.YA- &.. $\mathrm{Vr}$ & r.os & $. . \vee \Lambda-$ & $\cdot \cdot v$ & r.\&. & $\ldots 9-$ & $.7 \mathrm{~V}$ & r... & $. . \mathrm{VY}-$ &.. $\mathrm{VA}$ & |T.TH & لب باتقوم الفنادق رحلات السفاري الغير تقليدية للسائحين بمحافظة البحر الأحمر \\
\hline $1 . . \mathrm{r}-$ & $. .01-$ & 1.01 & $1.74-$ & $\cdot \cdot \mathrm{v}$ & T.7. & $\cdot . \varepsilon \wedge-$ & $\therefore$ vo & T.ro & 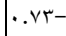 &. $\mathrm{Tr}$ & $y|r . \leqslant 1|$ & بات تصتل البنية التحتية السياحية بمحافظة البحر الأحمر نسبة عالية من السياحة المصرية . \\
\hline $1 . \S 1-$ & .71 & r.og & $. .79-$ &..$\wedge r$ & r.T. & $. .17-$ &.$v_{0}$ & r... & $. . \mathrm{Vr}-$ &.. $\mathrm{VA}$ & A.r.r. & لب||(المنشآت السياحية فى زيادة مستمرة وتطور دائم تقديم أفضل خدمة بالمحافظة . . \\
\hline$. . \mathrm{NV}-$ &.$\cdot \mathrm{v}$. & r.s. & $1.74-$ &.$\cdot \mathrm{v}$ & r.7. & ..纣- &.$v_{0}$ & r.ro & $. \mathrm{Vr}-$ &.$\cdot{ }^{\circ}$ & A.r.T & بالتوجد غرفة عمليات لحل المشكلات الطارئة وتزيل العقبات أمام السائحين بالمحافظة . \\
\hline $1.19-$ &.$v 1$ & r.or & $. .79-$ &..$\wedge r$ & r.T. & $\cdots 11$ & .9. & 1.91 & .r.o- &..$\wedge r$ & $r+17$ & بـاتتساوى الددن السياحية بالبحر الأحمر في أعداد السائحين سنوياً . \\
\hline $1 . .0-$ & r & r..$\leqslant$ & $\therefore \leqslant \Lambda-$ & 0.0 & r.7. & $. .1 \mathrm{y}-$ & $-\pi T$ & r.ro & . . $\leqslant \wedge-$ &..$\wedge r$ & $r$ r.ro & ـأتوع المنشآت السباحية بمحافظة البحر الأحمر مابين العام والخاص والاستثماري . \\
\hline $1.19-$ & $\cdots v 1$ & r.or & $1 . . r-$ & ..$\leqslant 1$ & r.V. & $\quad . . \leqslant \leqslant-$ & .70 & T.Tr & $. V Y-$ & 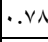 & A.r.ru & |ـ تهنتم هيئة تتشيط السباحة بالتواصل المستمر مع السائحين بعد مغادرة المحافظة . \\
\hline $1.79-$ & 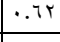 & r.7 & $0.79-$ & $\cdot \cdot \wedge r$ & T.r. & .r.o- &.$\wedge r$ & $r .17$ & $. V Y Y-$ &.$\cdot \mathrm{.}$ 人 & A.r.T & ل؛رياضة اليخوت أحد أهم عناصر الجذب السياحي نظراً لوجود ميناء غالب البحري . \\
\hline $1.01-$ & $\because v$. & r. & $1.77-$ & $\because \cdot v$ & r.7. & .ro- &.$\Delta r$ & r.17 & $1 . . v-$ &. .74 & $\begin{array}{r}y \\
\end{array} .0$. & لــتصتل السياحة الرياضية نسبة قلليلة جداً من السياحة بمحافظة البحر الأحمر \\
\hline
\end{tabular}

يتضح من جدول (T () استجابات فئات العينة علي عبارات المحور الثالث : سبل تتشيط السياحة الرياضية بمحافظة البحر الأحمر ، حيث جاءت استجابات (مديري القرى السياحية 


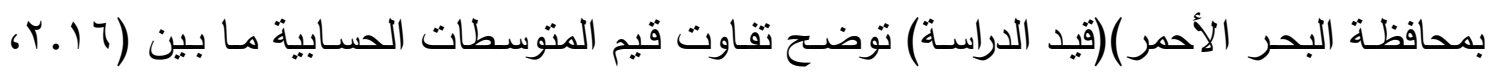

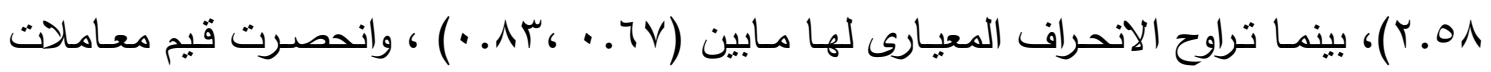

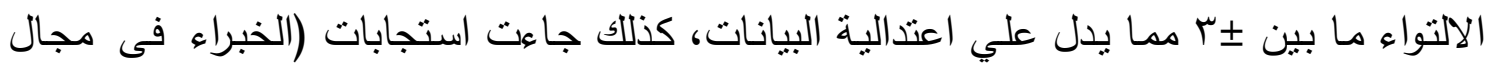

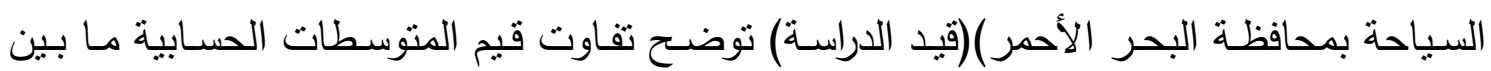

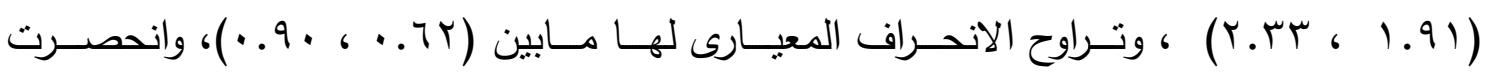

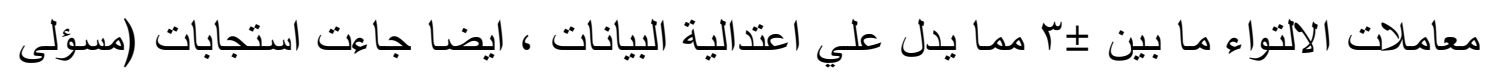

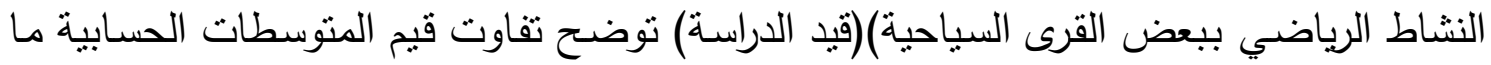

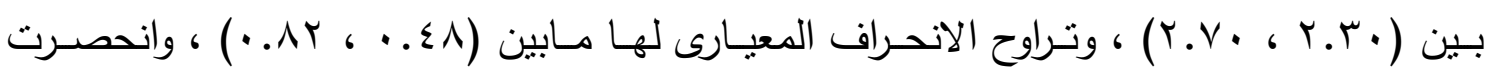

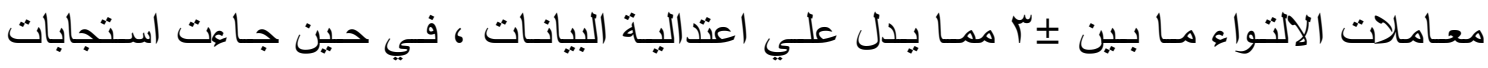

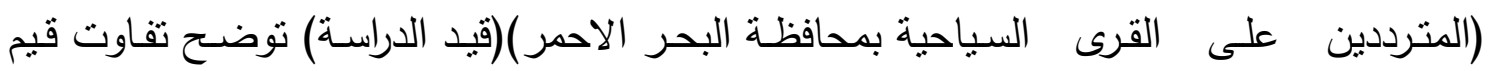

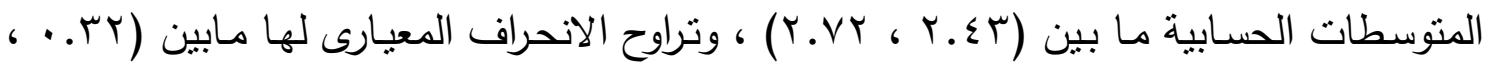

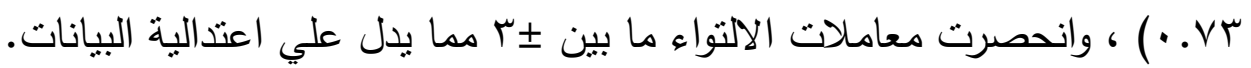
كما نتشير نتائج الجدول حول محور (سبل نتشيط السياحة الرياضية بمحافظة البحر الأحمر )

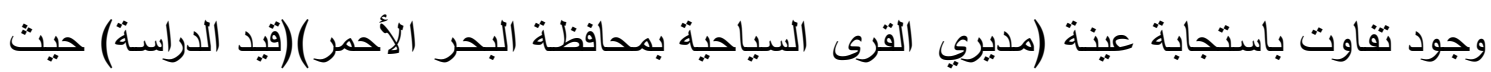

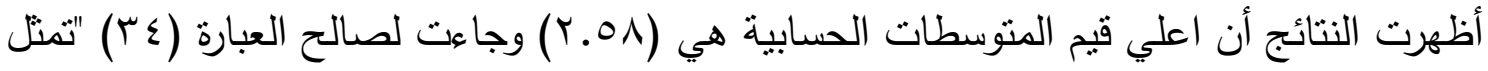

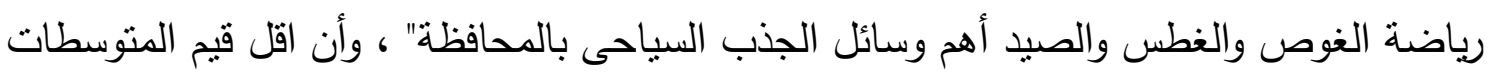

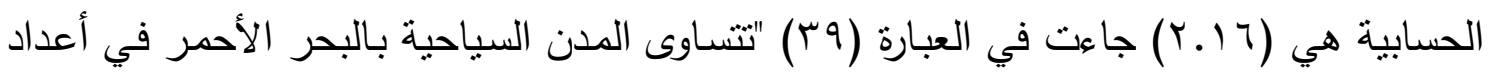

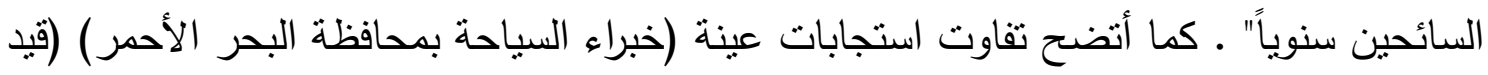

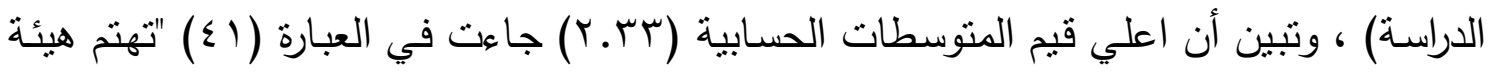

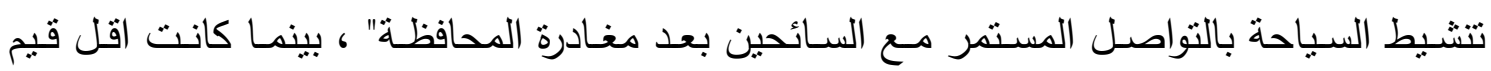

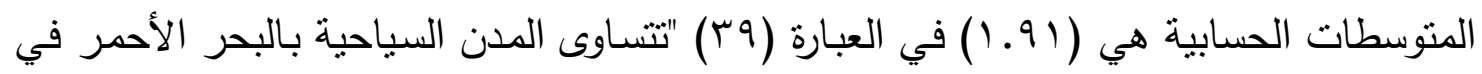
أعداد السائحين سنوياً" .

كذلك أتضـح تفاوت في استجابات عينة (مسئولي الانشطة الرياضية داخل القري السياحية)

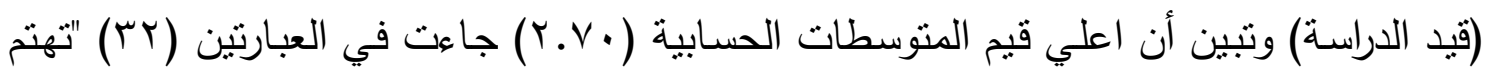

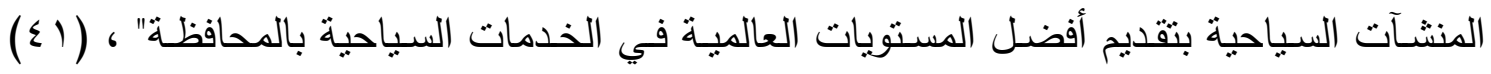

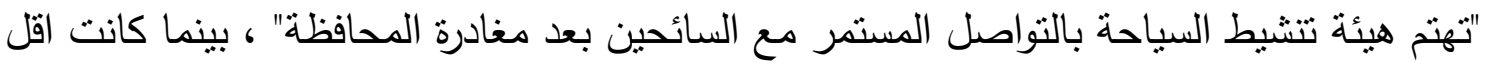

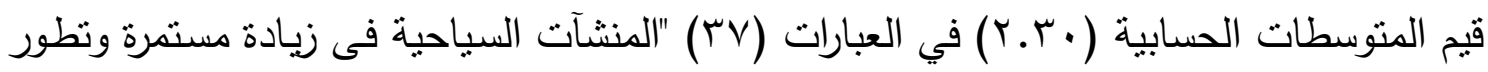

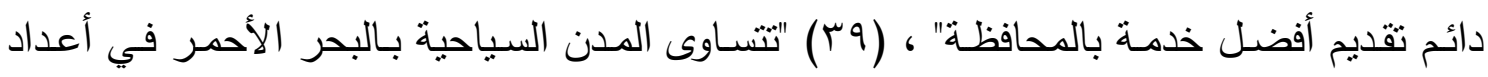




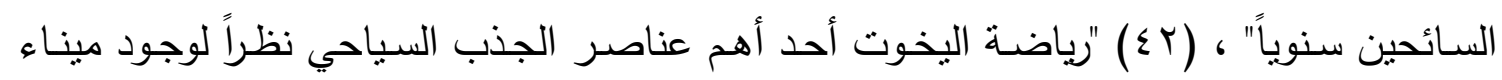

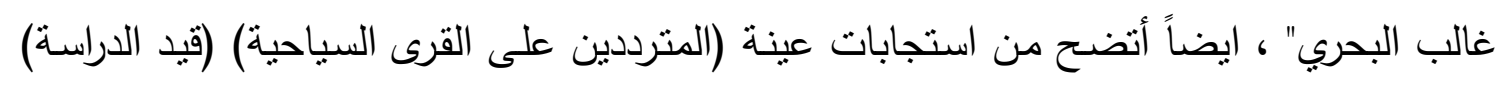

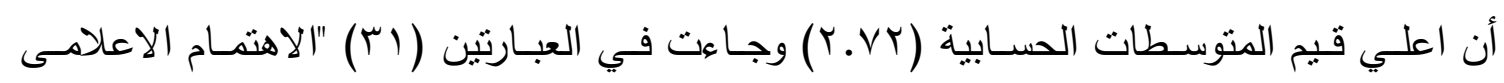

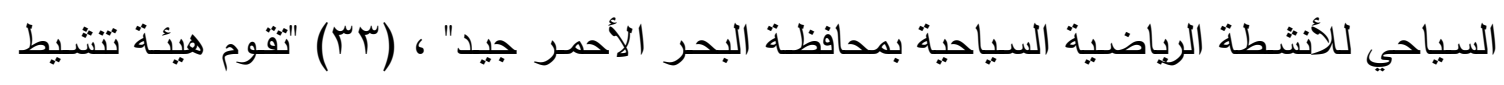

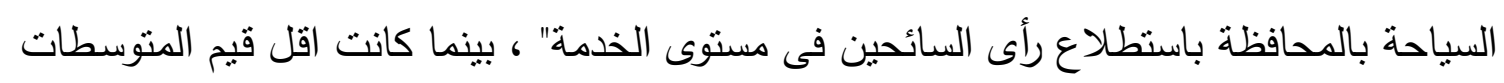

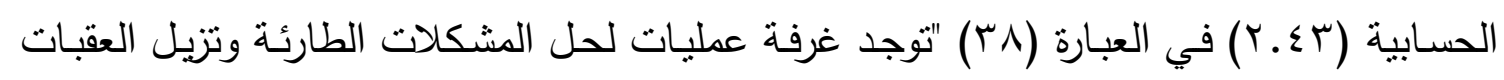

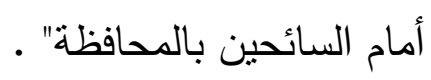

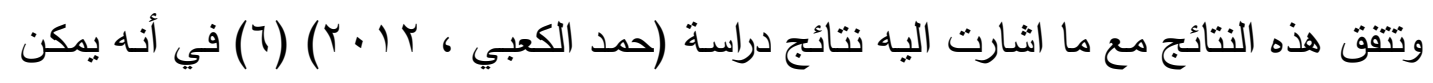

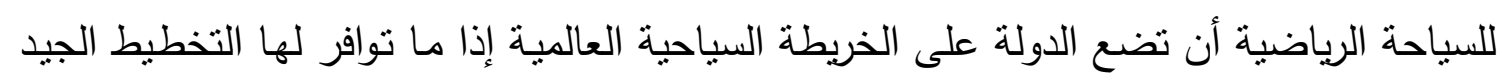

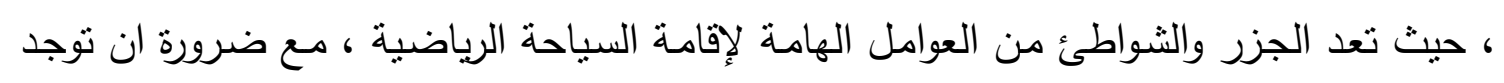

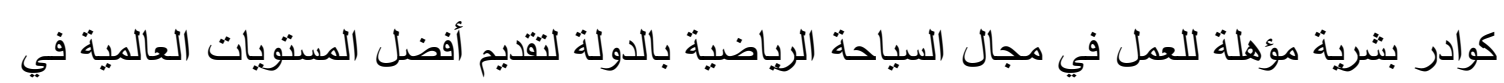
الخدمات السياحية للسياح المترددين على الاماكن السياحية.

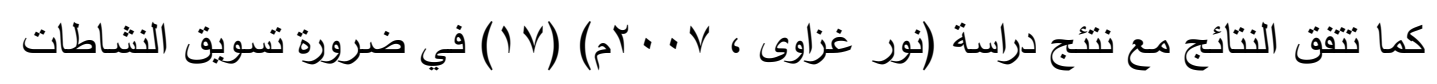

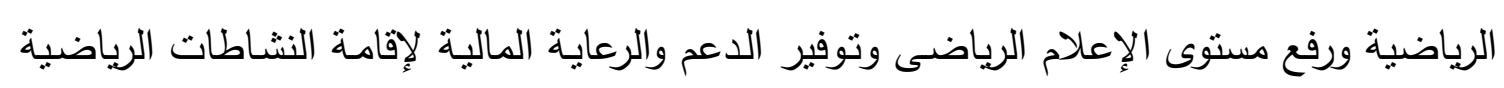

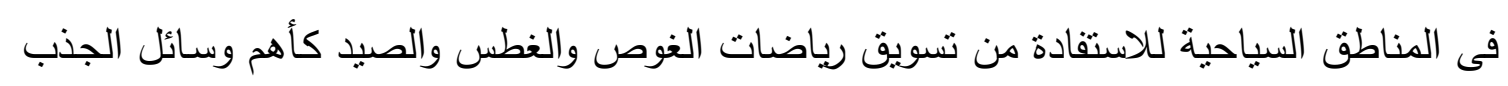
السياحى بالقرى والأماكن السياحية. ويفسر الباحثان أن تفاوت استجابات العينة لاعلي المتوسطات سواء لاستجابة مديري القري

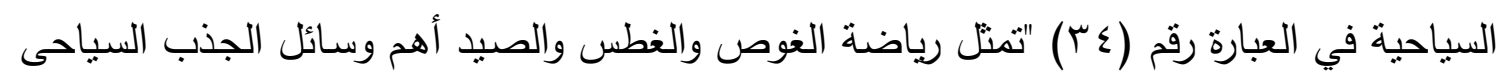

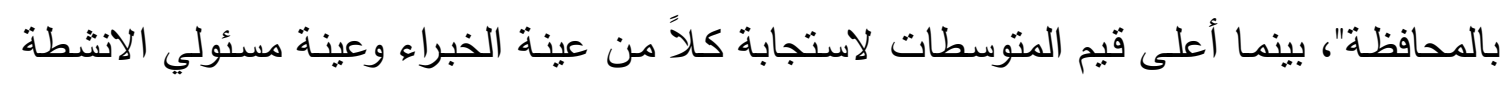

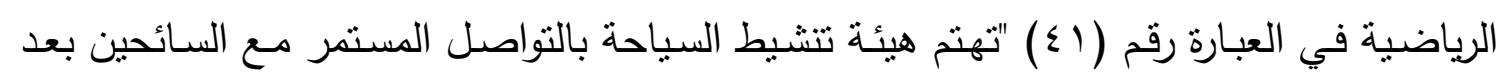

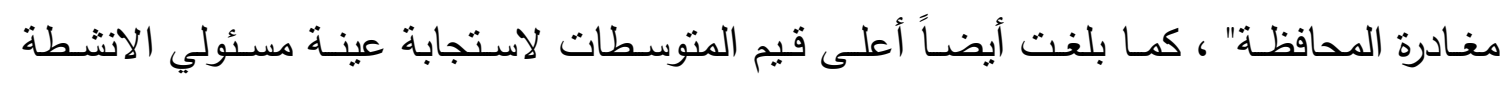

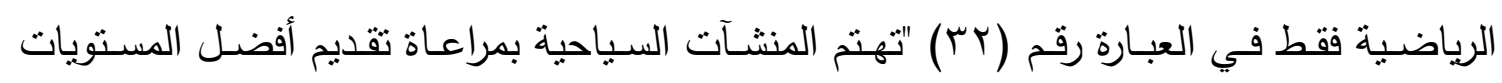

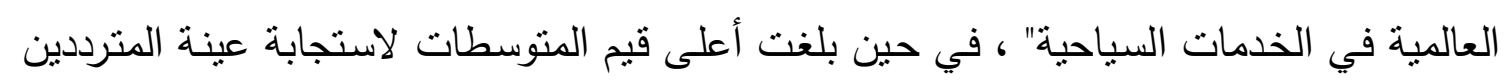

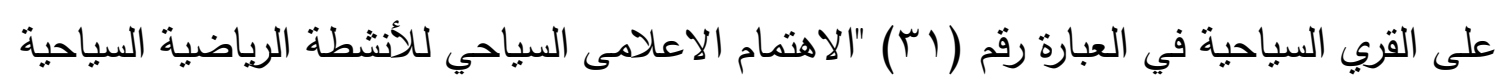

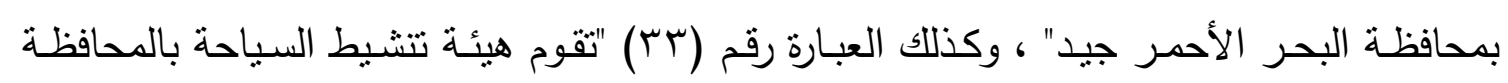

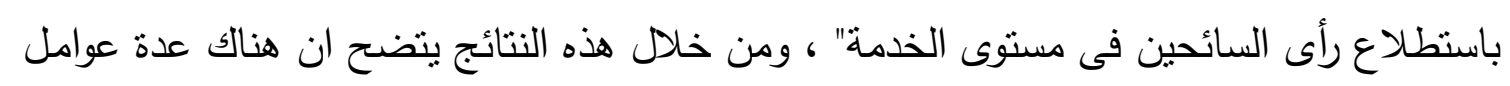

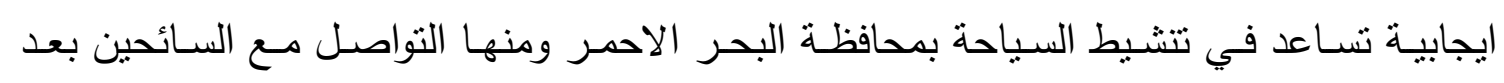

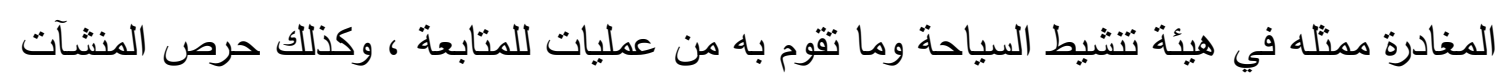


السياحية علي تقيم افضل المستويات السياحية العالمية والتقييم المستمر للخدمات وتقويم ماتحتاجه تلك المنشآت لتقديم افضل خدمة للسائح ، بينما كانت اقل قيم المتوسطات باستجابات العينة العينة فيما

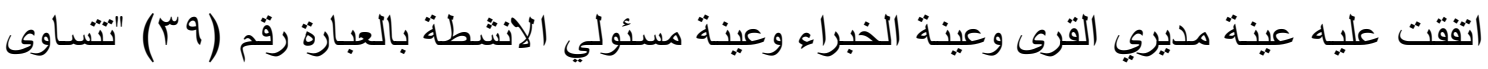

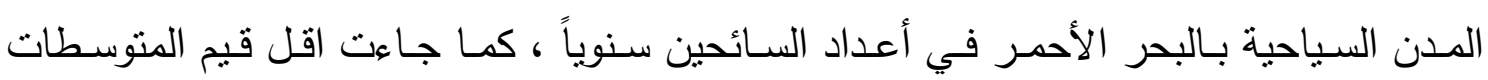

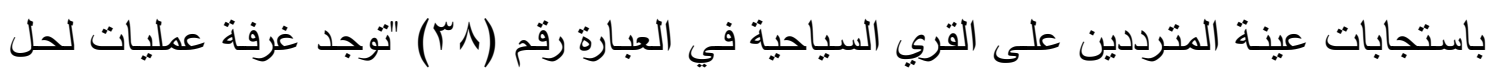

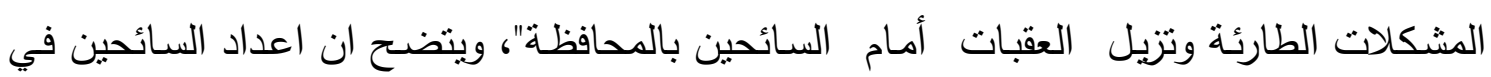

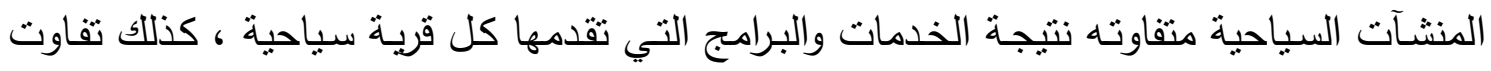

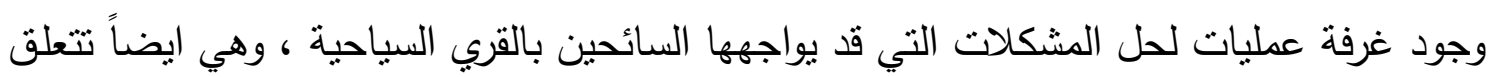

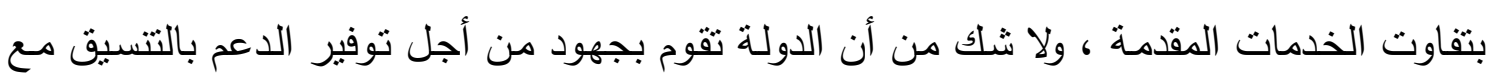

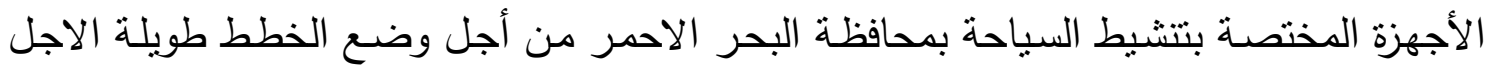

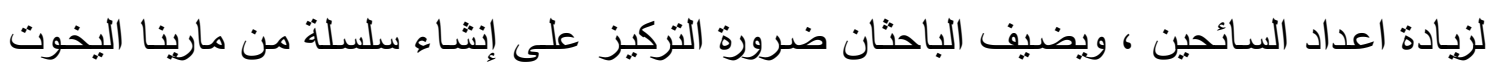

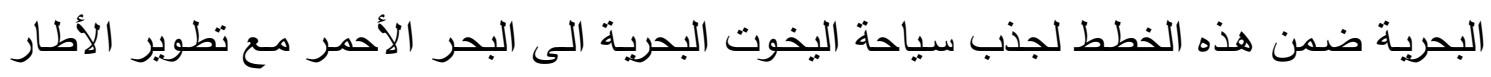

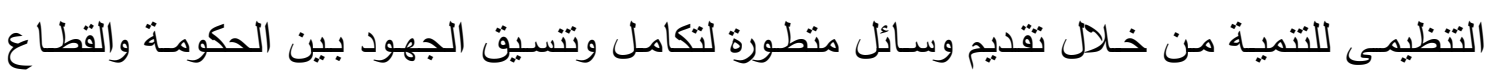
الخاص وتحديد أولويات الأستثمار التى تحتاجها عمليات التتفيذ للبرنامج القومى للتتمية السياحية

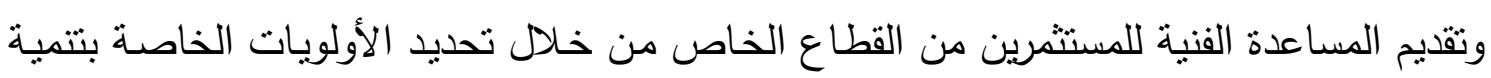

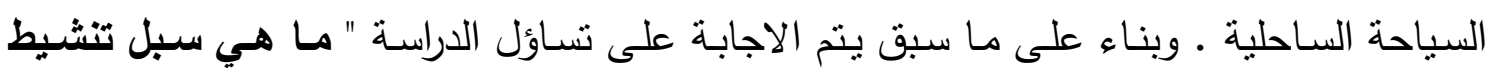

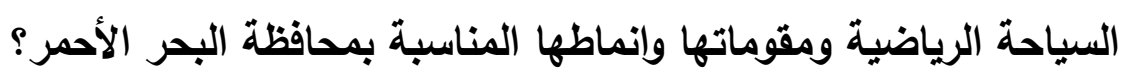
الاستخلاصات :

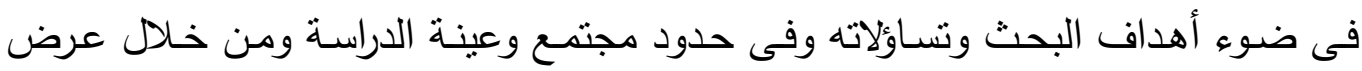

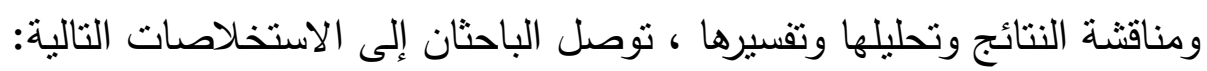
1- بالنسبة لمحور مقومات السياحة الرياضية بمحافظة البحر الأحمر تبين أن :

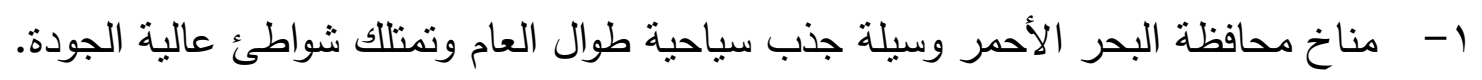

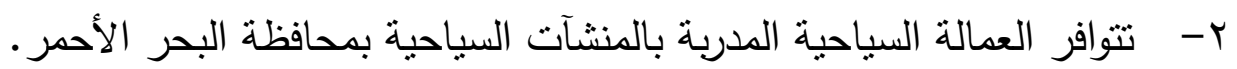
r- ت بوجد بمحافظة البحر الأحمر قاعات مجهزة بأحدث التكنولوجيا العالمية لاستقبال المؤتمرات.

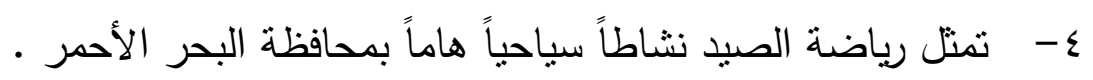

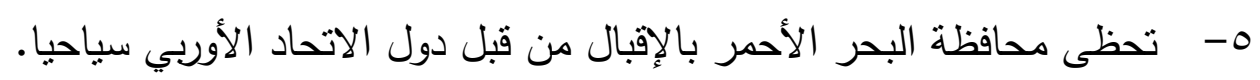
؟- لا يتم استضافة الفرق الرياضية المختلفة بمحافظة البحر الأحمر بشكل كافي. r- بالنسبة لمحور انماط السياحة الرياضية فى البحر الأحمر: 
1- يتم تفعيل موقع إلكتروني على شبكة المعلومات الدولية للترويج للأنثطة الرياضية السياحية.

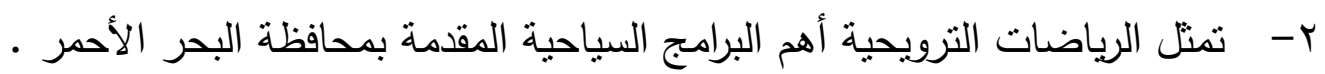

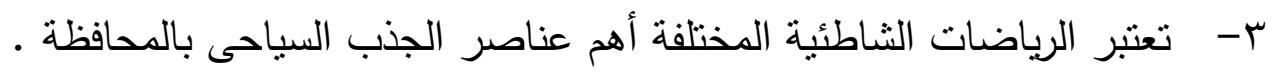

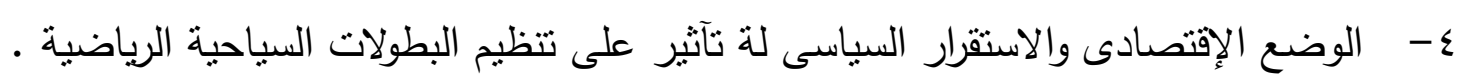

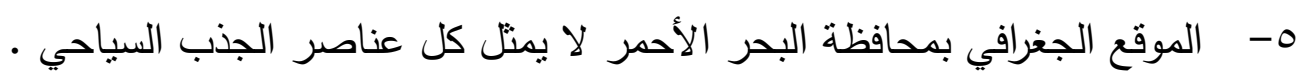

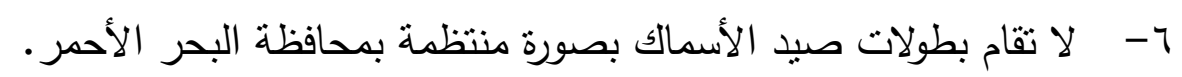

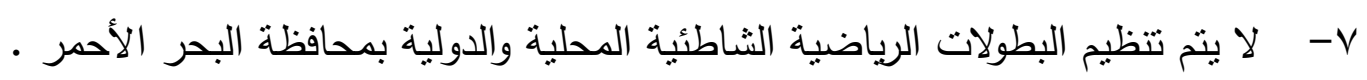

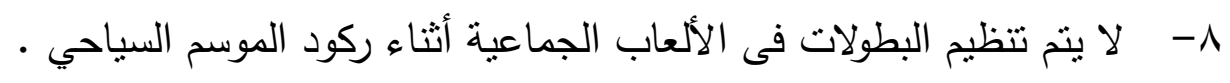

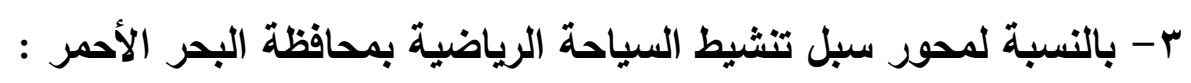

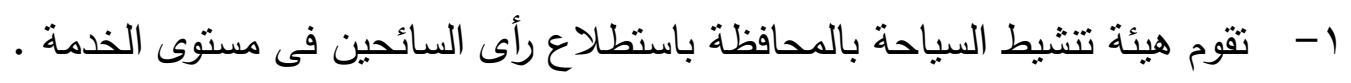
r- - تحرص المنشآت السياحية على تقديم أفضل المستويات العالمية في الخدمات السياحية.

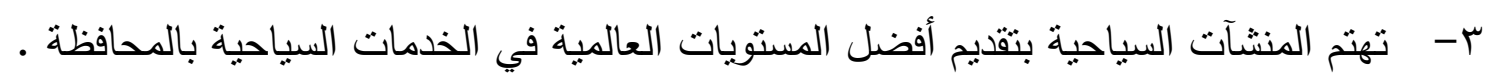

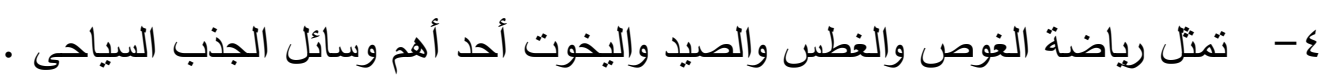
0- ضعف الاهتمام الاعلامى السياحي للأنشطة الرياضية السياحية بمحافظة البحر الأحمر . 7- - لا تتساوى الددن السياحية بالبحر الأحمر في أعداد السائحين سنوياً .

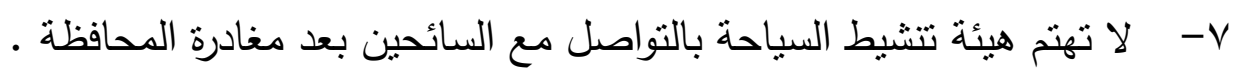
التوصيات :

فى ضوء أهداف وتساؤلات البحث و النتائج والاستخلاصات يوصى الباحثان بما يلى : لئل

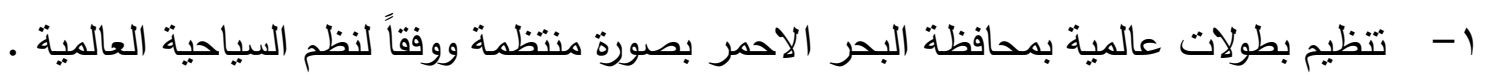

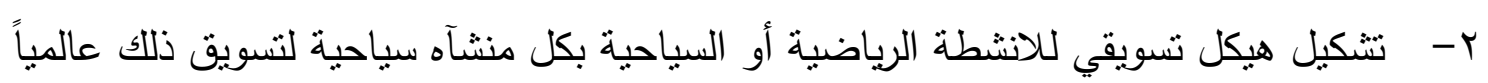

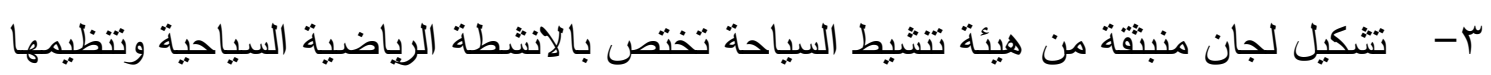

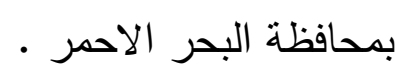

ع - اقامـة بطولات شـاطئية دوريـة في الالعـاب المختلفة بمـا يتماثــي دـع الطبيعـة الجغرافيـة

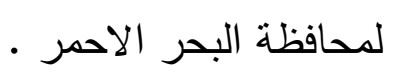

0- - تقديم الخدمات للسائحين وفقاً لطبيعة عادات وتقاليد سائحي كل دولة.

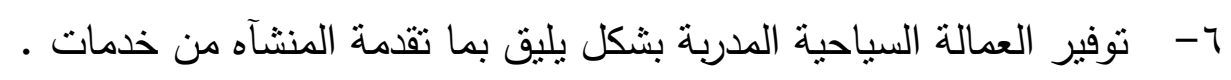

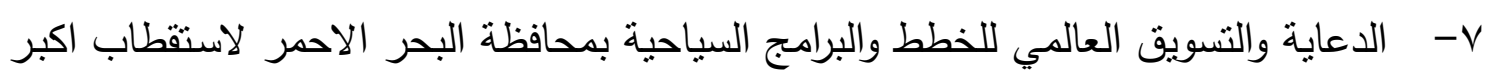
عدد ممكن من السائحين . 
1- - الاهتمام بتقديم برامج ترويحية لخدمة السائحين من كبار السن.

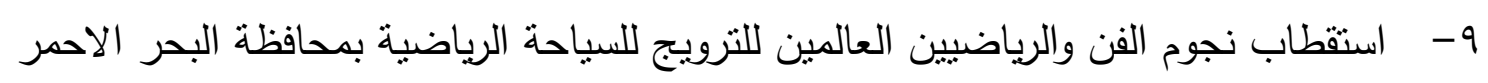

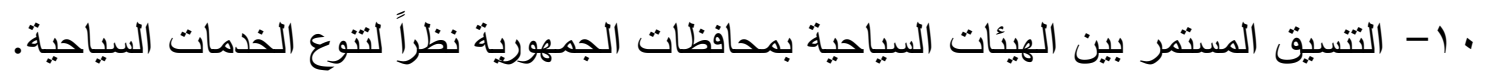

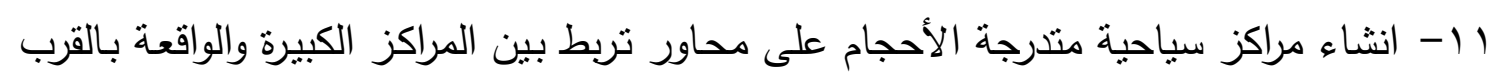
من المراكز العمرانية القائمة. 
1 - أحمد جمال محمد السيد : ( 17 ب) ، تقويم الامكانات المادية والبشرية فى مجال السياحة

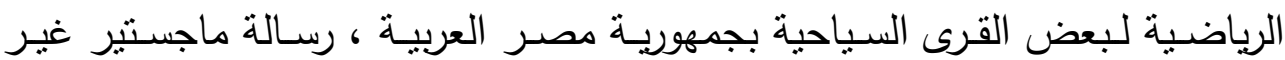

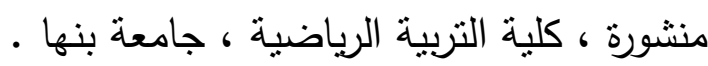

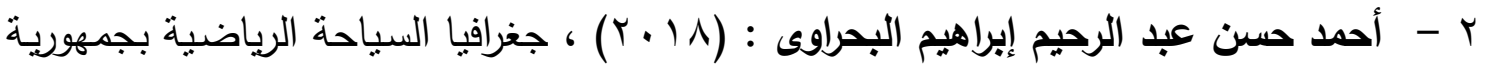

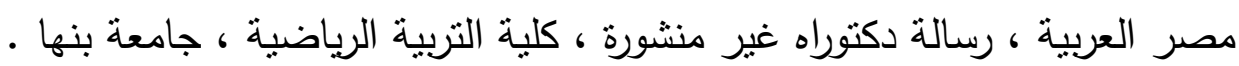

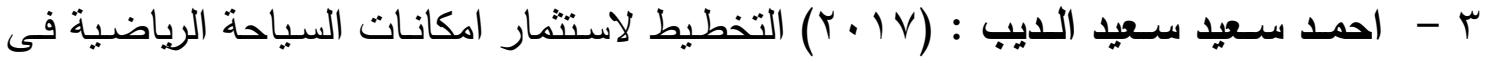

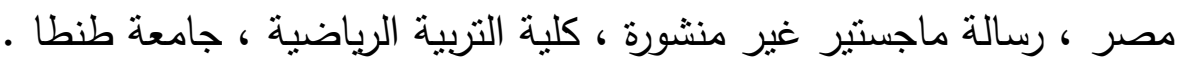

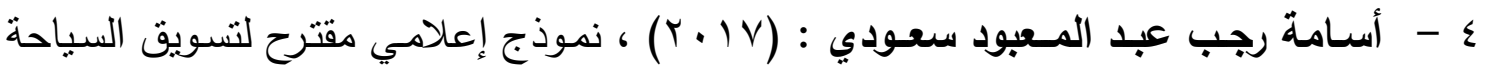

الرياضية في جمهوريـة مصر العربيـة ، رسـالة دكتوراه غير منشورة ، كلية التربيـة

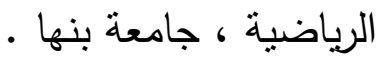

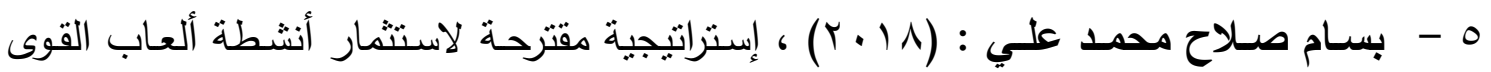

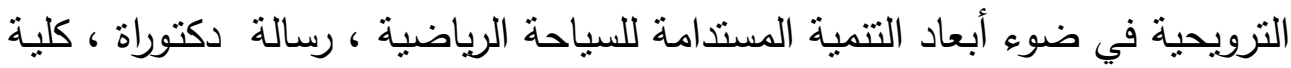
التربية الرياضية ، جامعة أسيوط.

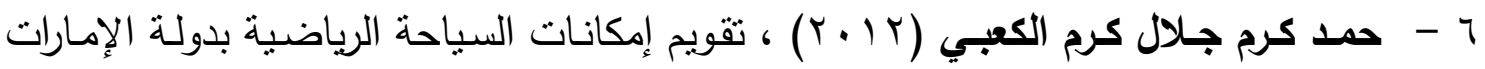

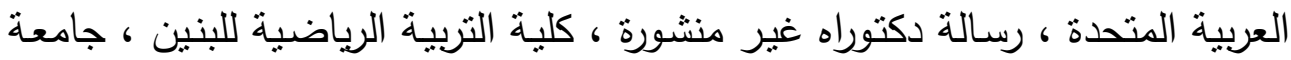

$$
\text { الاسكندرية. }
$$

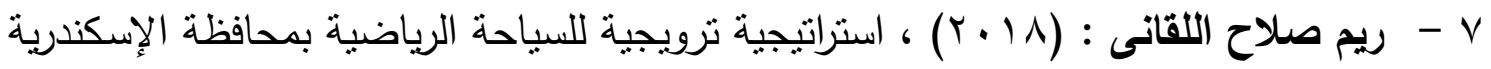

، رسالة دكتوراه غير منشورة ، كلية التربية الرياضية للبنات ، جامعة الاسكندرية .

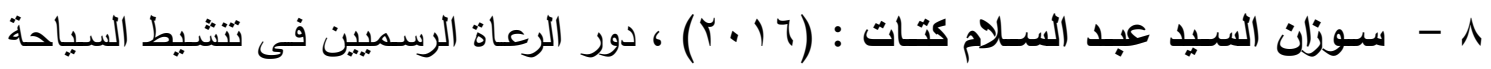
الرياضية ، ، رسالة ماجستير غير منشورة ، كلية السباحة والفنادق ، جامعة مدينة

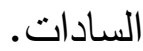

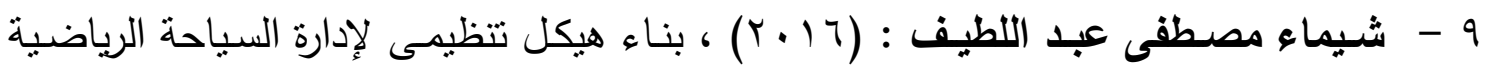

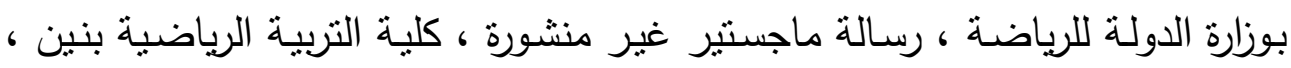

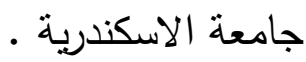

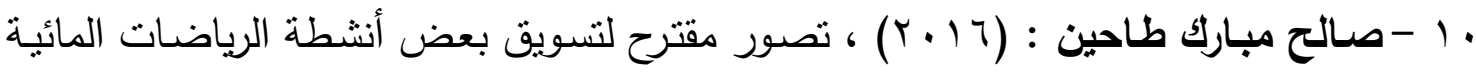
ذات الجذب السياحي بالجمهورية اليمنية ، رسالة ماجستير غبر منشورة ، كلية التربية

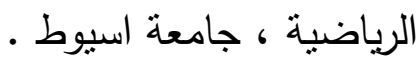


1 (1 -صلاح الدين عبد الوهاب : (999 (19) ، السياحة الدولية ، مطبعة زهران ، القاهرة .

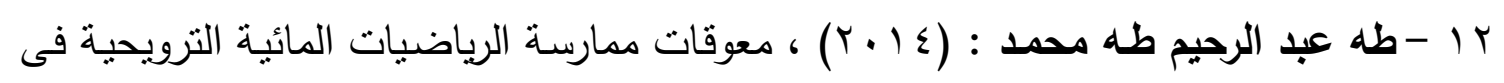

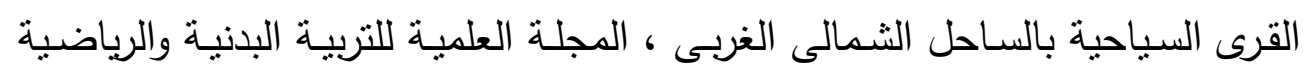

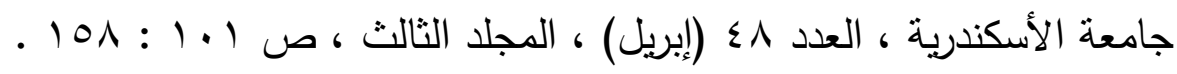

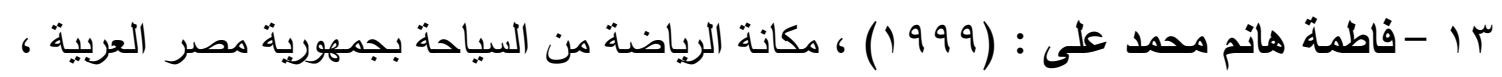

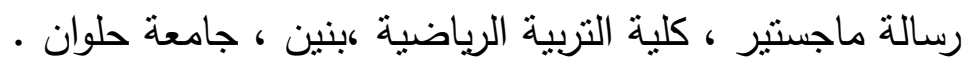

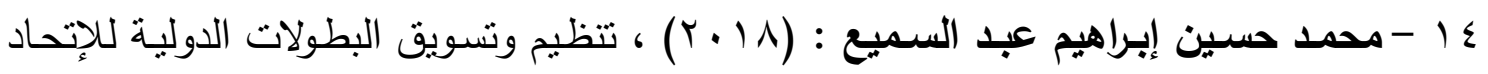

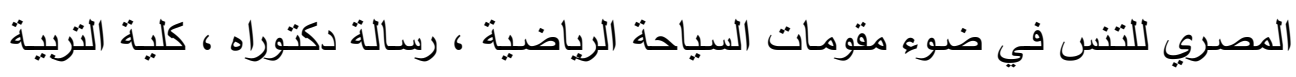

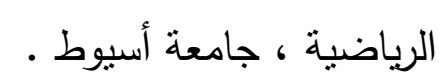

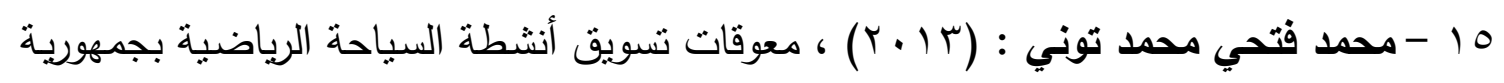

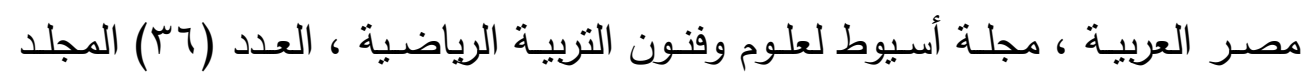

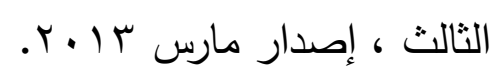

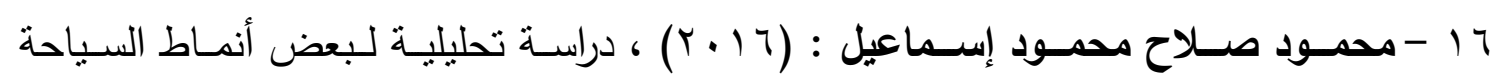

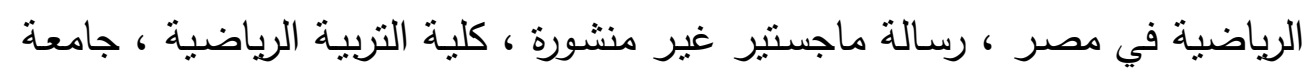

$$
\text { بني سويف. }
$$

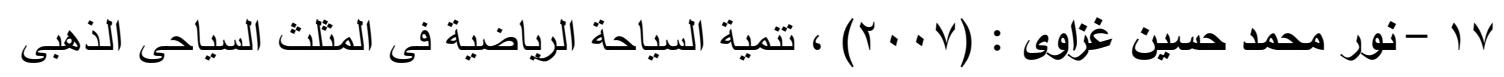

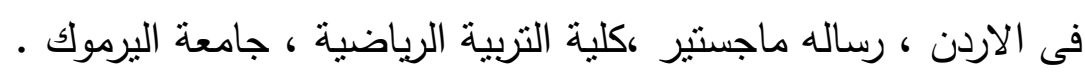

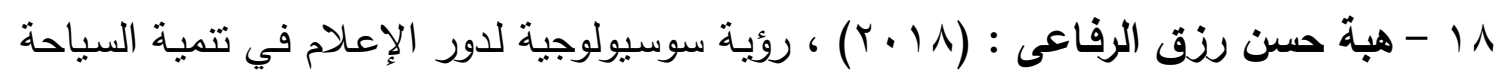

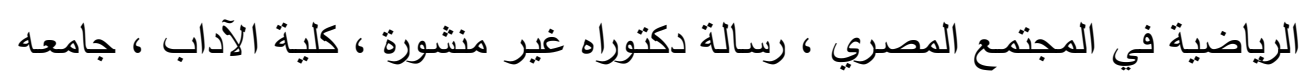


19 - Gelbman, A. (2019). Sport tourism and peace: crossing the contested wall. Tourism Geographies, 21(1), 175

20 - Ito, E., \& Hinch, T. (2019). Empirical research on sport tourism behaviour and experience. Impact, 2019(1), 73.

21 - Jeong, Y., Kim, S. K., \& Yu, J. G. (2019). Determinants of Behavioral Intentions in the Context of Sport Tourism with the Aim of Sustaining Sporting Destinations. Sustainability, 11(11), 3073.

22 - Kolenberg, M., \& Batra, A. (2019). The role of sport in the development of tourism: A study on awareness, opinion, preference and selected stakeholders contribution by sport tourists and non-sport tourists in Bangkok and Pattaya City. International Research E-Journal on Business and Economics, 1(2).

23 - Perić, M., \& Slavić, N. (2019). Event sport tourism business models: the case of trail running. Sport, Business and Management: An International Journal, 9(2), 172

24 - Tadini, R., de León, C. G. R., \& Gandara, J. M. (2019). Sport Clubs, Events and Tourism: the Case of Sport Events in Niteroi Using Stakeholders' Views. Revista Hospitalidade, 16(01), 53

25 - http://www.redsea.gov.eg/tourism/default.aspx 